\title{
味噌釀造に關する酵母の研究
}

農學士茂本正·利

(野田醬油株式會社試媛所)

昭和 13 年 4 月 27 日受理

\begin{tabular}{|c|c|}
\hline 目 & 次 \\
\hline 論 & 繁最邂 pII \\
\hline 驗 & 13. 食監に對する抵抗 \\
\hline 試 驗筫 料 & 14. 㡀萄棺に對す万抵执 \\
\hline II. 形態學的性算 & 15. 生 酸 試 驗 \\
\hline 1. 細胞の形態 & 16. 酸 酝 試 驗 \\
\hline 2. 液體培秦 & 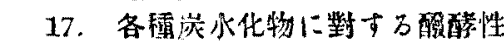 \\
\hline 3. 穿刺培養 & 18. 䇺素同化能筎 \\
\hline 4. 斜面培養 & 19. 敞類同 化能否 \\
\hline 5. 聚落の形態 & 20. 酒精に對すち發奇能否 \\
\hline 6. 昧唓に移植ざ万試噞 & 21. 香氮の試驗 \\
\hline III，生理學的性算 & 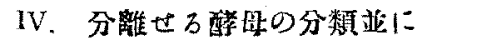 \\
\hline 7. 皮膜 9 生虐 & 類緣及び標鰴 \\
\hline 8. 溶蹘性の强哥 & v. 考察 \\
\hline 9. 胞子の生産 & VI. 總 括 \\
\hline 10. 發青溫度 & 參考文独 \\
\hline 11. 死 隇溫 度 & 附圆 \\
\hline
\end{tabular}

緒論

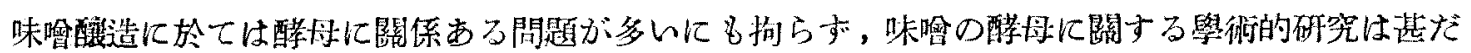
䟞的。

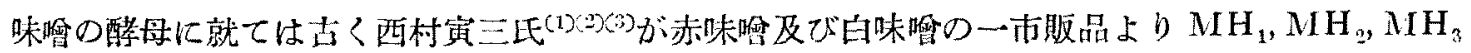
及び $\mathrm{IH}_{4}$ なる四種類の醋母分分離し之等の菌學的檢絜考行ひ， $\mathrm{MH}_{1}$ は Torura shoyu， $\mathrm{MH}_{2}$ は Torula miso var. minuta nov. sp., $M H_{3}$ 及び $M H_{4}$ 殆દ゙同雷にして Pseudomonilia miso $A$ and

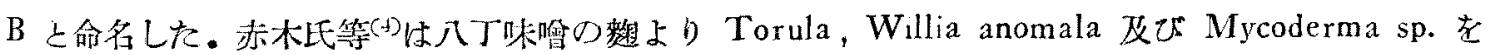

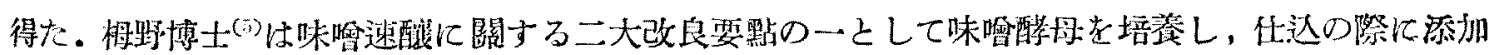

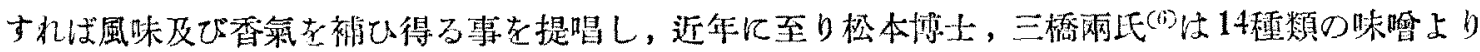

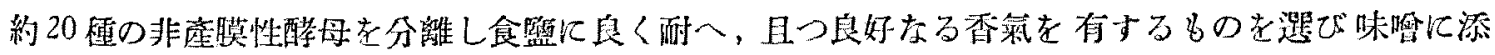

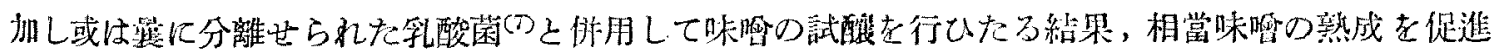
せしむる效果ある事を報告して居る。

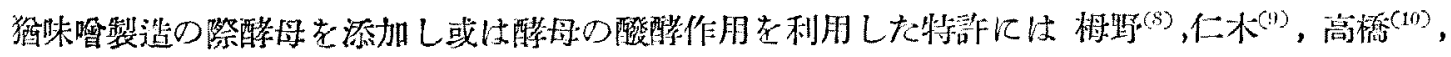

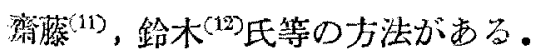

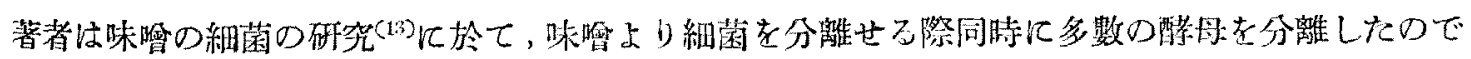
其後の研究絬果老郝告したいと思ふ。

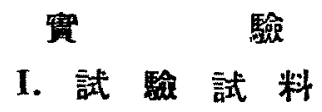

各種の味瞥上り分離したる酵母の菌株並に酸造場名を列舉すれば次の如し。 


\begin{tabular}{|c|c|c|c|}
\hline 荫株番諕 & 潂造 場 名 & 醀 造 埸 地 名 & 備 \\
\hline H 1 & 不山末松商店 & 新渴市本町通七番町 & 越後味 㗍 \\
\hline II 2 & " & " & 11 \\
\hline H 3 & 犲茂味嘫合資會社. & 新晹橴佳渡郡犸茂村 & 佐渡味嘫特等品 \\
\hline II 4 & " & " & " \\
\hline II 5 & $\prime \prime$ & $" \prime$ & 同 並等品 \\
\hline II 6 & $\prime \prime$ & $\prime \prime$ & " \\
\hline II 19 & 葛西嘉右衛門商占 & $\prime \prime$ & 传渡救嘫 \\
\hline It 35 & 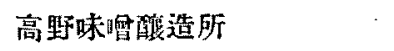 & 新渴縣侾渡郡畺野村 & "l \\
\hline $\mathrm{H} 7$ & 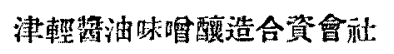 & 青森縣南津輕郡大緬町 & 津 輕 味 唄 \\
\hline $\mathrm{H} 8$ & " & " & " \\
\hline if 9 & 渡㩧佐助商店 & 青森市大町 & $\prime \prime$ \\
\hline II 10 & $\prime \prime$ & " & $\prime \prime$ \\
\hline II 11 & $" \prime$ & $\prime \prime$ & $" \prime$ \\
\hline H 34 & $\prime \prime$ & "I & $\prime \prime$ \\
\hline II 12 & 長 坆 墑 占 & 秋田縣堵田町 & \\
\hline II 33 & " & " & \\
\hline II 14 & 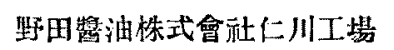 & 朝解仁川附烃林町 & ほまれ白味噌 \\
\hline II 16 & " & "l & " \\
\hline If 15 & $\prime \prime$ & " & 同赤 \\
\hline II 28 & 低中味嘫製造合資會社 & 廣噳縣稫山市 & 府中味唄 \\
\hline H 17 & 津田源次郎商店 & 京都府伏見市 & 西京白味唄 \\
\hline If 18 & " & . & $\prime \prime$ \\
\hline H 21 & $\prime \prime$ & "r & " \\
\hline $\mathrm{H} 23$ & 大塚阔 店 & 長野縣小話町 & 信州味嘼 \\
\hline H 24 & " & $\prime \prime$ & $\prime \prime$ \\
\hline II 25 & $" \prime$ & 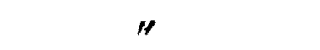 & $\prime \prime$ \\
\hline 1126 & " & I & $" \prime$ \\
\hline II 31 & 大熊武右衡門陷怎 & 笴玉縣川口市元鄉 & 春 味 噌 \\
\hline II 36 & $"$ & $\prime \prime$ & $" \prime$ \\
\hline H 37 & 由中德兵衛墑店 & $\prime \prime$ & 仙茥 味 嘫 \\
\hline I 32 & 大室彌重商店 & 同縣北足立郡土合村 & 麥味 囎 \\
\hline H 22 & 大友商 店 & 東京市芝區芝浦二丁目 & 江戶味㬝 \\
\hline $\mathrm{H} 122$ & $" 1$ & $\prime \prime$ & $\prime \prime$ \\
\hline II 20 & & 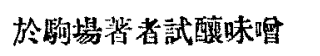 & ほまれ味噌 \\
\hline
\end{tabular}

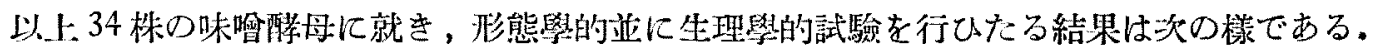

\section{II. 形態學的性 犋}

1. 細胞の形態 (其一).

数汁 (Bllg. $8^{\circ}$ ) 老試驗管に探り各酵打の一白金耳移植し， $25^{\circ} \mathrm{C} の$ Thermostat K5 7 日間 培荃後沈澱酵母に就き䠐察した。 


\begin{tabular}{|c|c|c|c|c|}
\hline 菌株番號 & 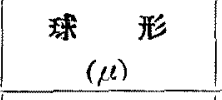 & $\begin{array}{l}\text { 棈 回 形 } \\
(\mu) \\
\end{array}$ & $\begin{array}{l}\text { 腸 詰 形 } \\
(\mu) \\
\end{array}$ & 摘 \\
\hline $\mathrm{H}$ & $\begin{array}{l}\text { 極限 } 2.0 \sim 7.0 \\
\text { 普通 } 4.0 \sim 5.0\end{array}$ & $\begin{array}{r}(3.5 \sim 4.0) \times \\
\quad(5.0-6.0)\end{array}$ & & 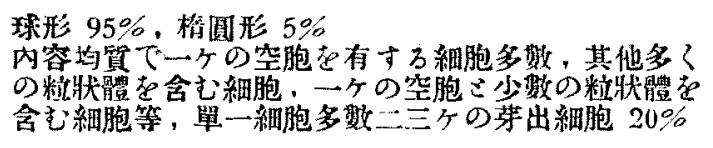 \\
\hline $\mathrm{H}$ & $\begin{array}{l}\text { 極限 } 3.0 \sim 8.0 \\
\text { 盖通 } 6.5 \sim 7.5\end{array}$ & $\begin{array}{r}(4.0 \sim 6.0) \times \\
(6.0 \sim 9.0)\end{array}$ & $\begin{array}{c}(3.0 \sim 4.0) \times \\
(8.0 \sim 15.0)\end{array}$ & 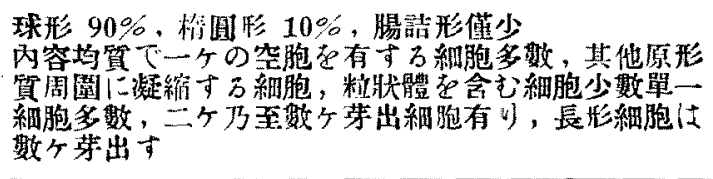 \\
\hline H 3 & $\begin{array}{l}\text { 扬限 } 4.0 \sim 8.0 \\
\text { 瑟通 } 6.0 \sim 7.0\end{array}$ & $\begin{array}{l}(4.0 \sim 6.0) \times \\
\quad(6.0 \sim 80) \\
\text { 椙通 } 5.0 \times 7.0\end{array}$ & & 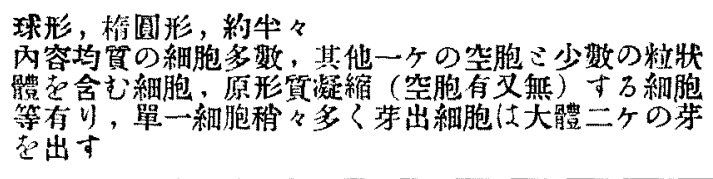 \\
\hline II 4 & $\begin{array}{l}\text { 極限 } 3.0 \sim 8.0 \\
\text { 缢通 } 4.0 \sim 6.0\end{array}$ & & & 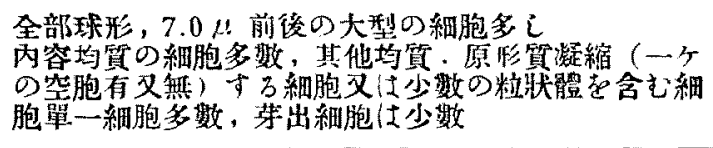 \\
\hline $\mathrm{H} 5$ & 極限 $3.0 \sim 8.0$ & $\begin{array}{c}(5.0 \sim 6.5) \times \\
(7.0 \sim 8.5)\end{array}$ & & 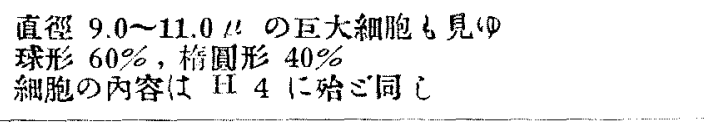 \\
\hline H 6 & $\begin{array}{l}\text { 桠限 } 4.0 \sim 8.0 \\
\text { 態通 } 5.0 \sim 6.0\end{array}$ & $\begin{array}{c}(4.0 \sim 7.0) \times \\
(7.0 \sim 8.0)\end{array}$ & & II 4 に殆ご同じ \\
\hline II 7 & 極限 $3.0 \sim 8.0$ & $\begin{array}{l}(5.0 \sim 6.0) \times \\
(6.0 \sim 8.0) \\
\text { 傿通 } 5.0 \times 7.0\end{array}$ & & 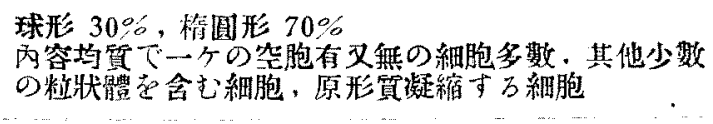 \\
\hline H 8 & 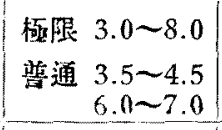 & $\begin{array}{l}(3.0 \sim 7.0) \times \\
(4.0 \sim 8.0)\end{array}$ & & 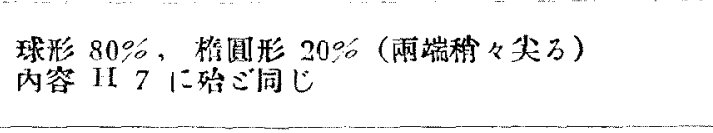 \\
\hline II 9 & 極限 $3.0 \sim 7.0$ & $\begin{array}{l}(4.0 \sim 5.0) \times \\
(6.0 \sim 8.0)\end{array}$ & 构溦形 & 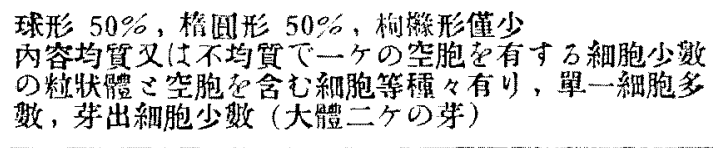 \\
\hline H 10 & $\begin{array}{l}\text { 極限 } 4.0 \sim 10.0 \\
\text { 智道 } 7.0 \sim 8.0\end{array}$ & & & 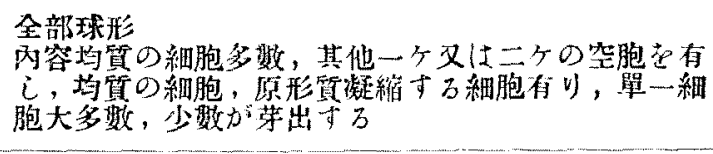 \\
\hline II 11 & 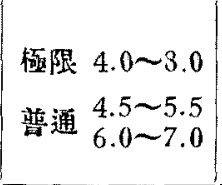 & & " & 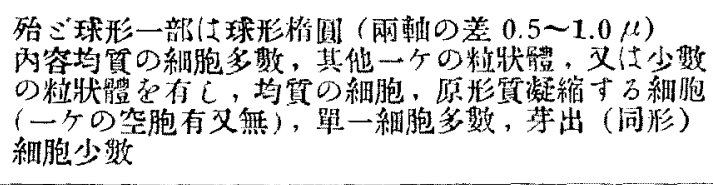 \\
\hline I 12 & 極限 $3.0 \sim 8.0$ & $\begin{array}{l}(4.0 \sim 6.0) \times \\
\quad(5.0 \sim 7.0) \\
\text { 又は } 4.0 \times 6.0\end{array}$ & . & 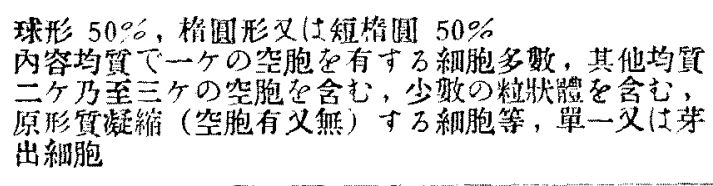 \\
\hline H 14 & $\begin{array}{l}\text { 極限 } 4.0 \sim 9.0 \\
\text { 普通 } 7.0 \sim 8.0\end{array}$ & $4.0 \times 6.0$ & & 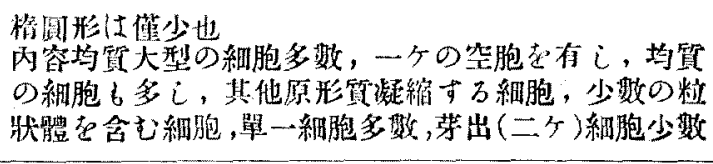 \\
\hline
\end{tabular}




\begin{tabular}{|c|c|c|c|c|}
\hline II 15 & 極限 3.0 - 7.0 & & & 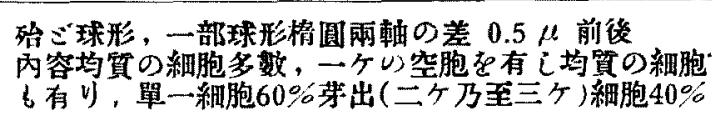 \\
\hline H 16 & 極限 $3.5 \sim 8.0$ & $\begin{array}{c}(3.5 \sim 5.0) \times \\
(6.0 \sim 8.0)\end{array}$ & $\begin{array}{c}(3.0 \sim 4.0) \times \\
(8.0 \sim 15.0)\end{array}$ & 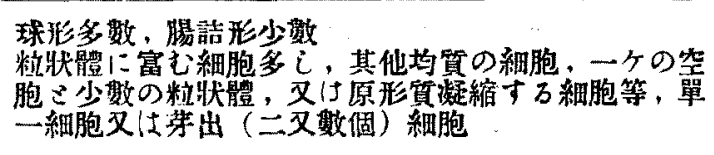 \\
\hline H 17 & 桠限 $2.0 \sim 4.0$ & \begin{tabular}{|c|}
$(1.5 \sim 3.01 \times$ \\
$(3.0-6.0)$ \\
皮膜 $(5.0 \sim 6.0)$ \\
$\times(7.0 \sim 8.0)$
\end{tabular} & $\begin{array}{c}(1.0 \sim 1.5) \times \\
(5.0 \times 10.0)\end{array}$ & 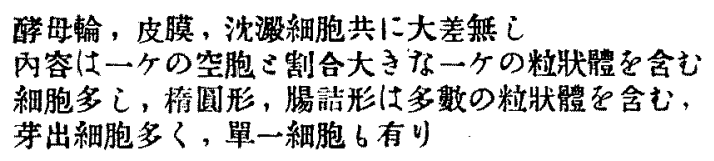 \\
\hline II 18 & 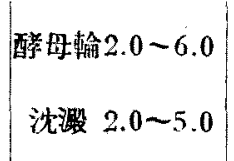 & $\begin{array}{r}(1.5 \sim 4.0 \times x \\
(3.0 \sim 6.0) \\
(1.5 \sim 5.0 \cdot \times \\
(3.0 \sim 7.0)\end{array}$ & $\begin{array}{r}(25-3.5) \times \\
(5.0 \sim 10.0) \\
(2.5-3.5) \times \\
(9.0-15.0)\end{array}$ & 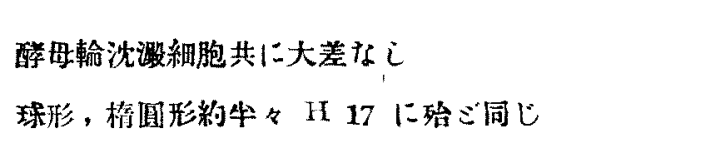 \\
\hline H 19 & $\begin{array}{l}\text { 㢦限 } 3.5 \sim 8.0 \\
\text { 背道 } 6.0 \sim 7.0\end{array}$ & & & 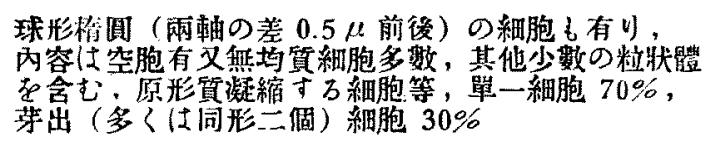 \\
\hline H 20 & $\begin{array}{l}\text { 㢦限 } 4.0 \sim 8.0 \\
\text { 些通 } 5.0 \sim 7.0\end{array}$ & $\begin{array}{r}(4.0-6.0) \times \\
(6.0-8.0)\end{array}$ & $\begin{array}{r}(3.0 \sim 4.0) \times \\
(8.0 \sim 10.0)\end{array}$ & 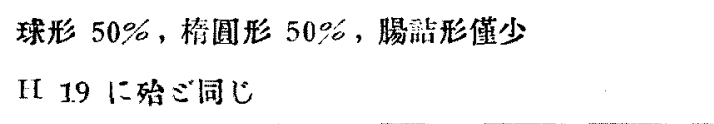 \\
\hline H 21 & 極限 $4.0 \sim 8.0$ & & & 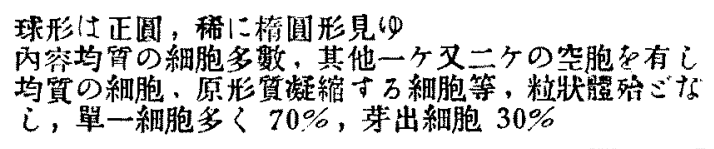 \\
\hline II 22 & 㢦限 $2.0 \sim 7.0$ & $\begin{array}{r}(2.0 \sim 5.0) \times \\
(3.0-7.0)\end{array}$ & & 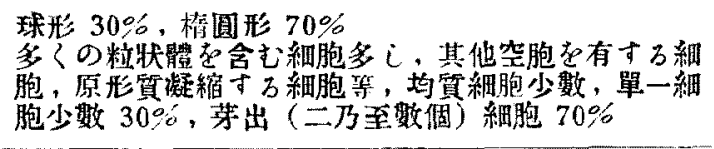 \\
\hline 1123 & 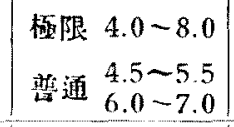 & & & 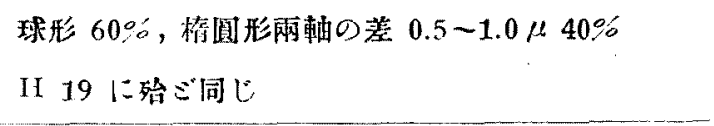 \\
\hline II 24 & $\begin{array}{l}\text { 極限 } 4.0 \sim 10.0 \\
\text { 第通 } 7.0 \sim 8.0\end{array}$ & & & 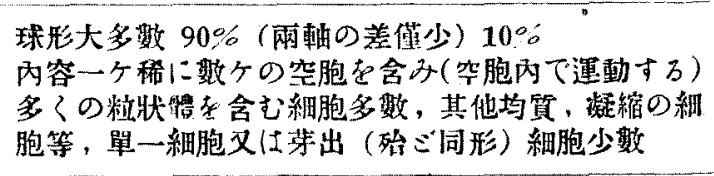 \\
\hline II 25 & 極限 $4.0 \sim 8.0$ & & . & 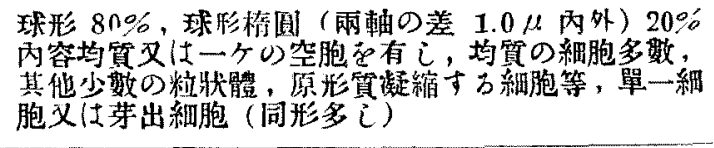 \\
\hline II 26 & 極限 $4.0 \sim 8.0$ & & & 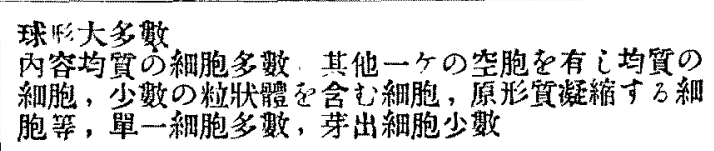 \\
\hline HI 28 & 極限 $2.0 \sim 6.0$ & $\begin{array}{l}(2.0 \sim 5.0) \times \\
\quad(3.0 \sim 6.0)\end{array}$ & $\begin{array}{l}(2.0 \sim 3.0) \times \\
(10.0 \sim 20.0)\end{array}$ & 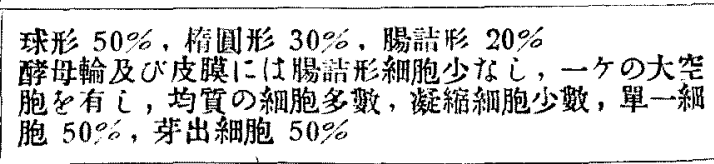 \\
\hline II 31 & 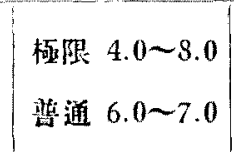 & & & 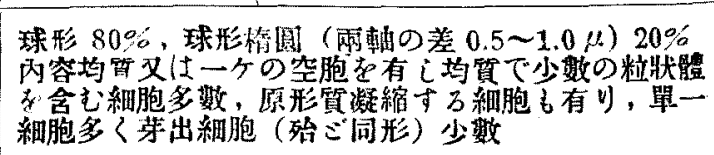 \\
\hline
\end{tabular}




\begin{tabular}{|c|c|c|c|c|}
\hline II 32 & 極限 $3.5 \sim 8.0$ & $\begin{array}{r}(3.5 \sim 6.0) \times \\
\quad(5.0 \sim 9.0)\end{array}$ & & 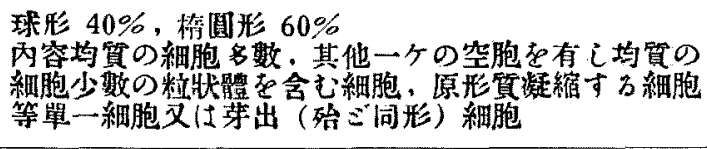 \\
\hline H 33 & 極限 $3.5 \sim 8.0$ & & & 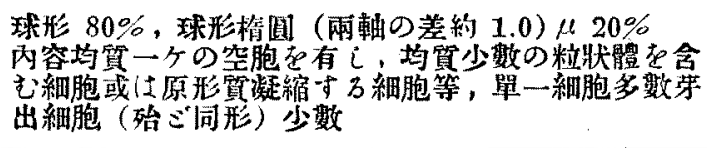 \\
\hline H 34 & 極限 $4.0 \sim 8.0$ & $\begin{array}{r}(5.0 \sim 7.0) \times \\
\quad(6.0 \sim 9.0)\end{array}$ & & 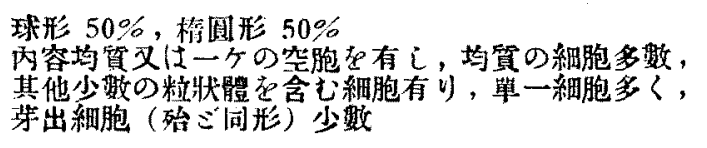 \\
\hline ff 35 & $\begin{array}{l}\text { 㥛限 } 3.0 \sim 7.0 \\
\text { 兹通 } 40 \sim 5.0\end{array}$ & & $\begin{array}{l}(3.5 \sim 4.0) \times \\
\quad(15.0 \sim 25.0)\end{array}$ & 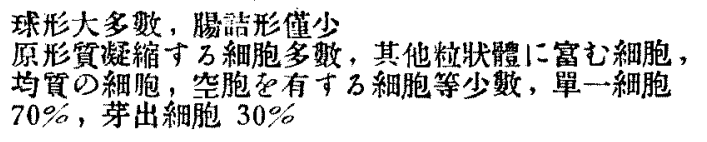 \\
\hline If 36 & $\begin{array}{l}\text { 皮膜 } 2.0 \sim 5.0 \\
\text { 沈潅 } 2.0 \sim 7.0\end{array}$ & $\begin{array}{l}(2.0 \sim 7.0) \\
\times(4.0 \sim 10.0) \\
(2.5 \sim 6.0) \times \\
\quad(5.0 \sim 8.0)\end{array}$ & $\begin{array}{l}(2.0 \sim 4.0) \times \\
(8.0 \sim 20.0) \\
(4.0 \sim 5.0) \times \\
(10.0 \sim 15.0) \\
(2.5 \sim 3.5) \times \\
(8.0 \sim 15.0)\end{array}$ & 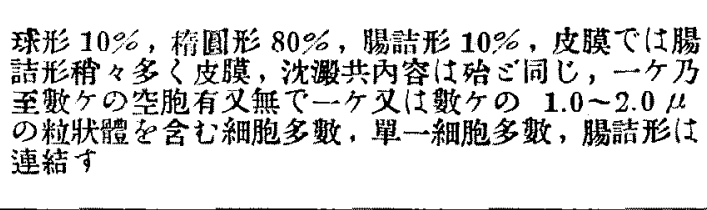 \\
\hline II 37 & 極限 $3.0 \sim 8.0$ & & & 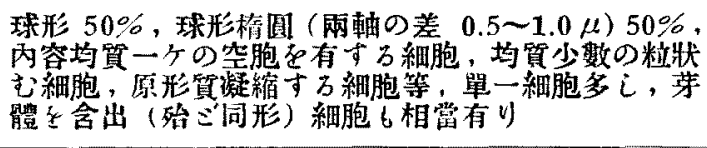 \\
\hline II 122 & 極限 $2.0 \sim 5.0$ & $\begin{array}{l}(2.0 \sim 6.0) \times \\
\quad(3.5 \sim 8.0)\end{array}$ & & 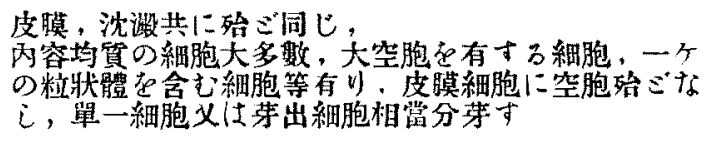 \\
\hline
\end{tabular}

細胞の 形態 (其二).

Gorodkowa-agar. ( $\frac{1}{4} \%$ Glucose $, \frac{1}{2} \% \mathrm{NaCl}, 1 \%$ 肉エキス，1\% Peptone 及び $2 \%$ 寒天)に刹

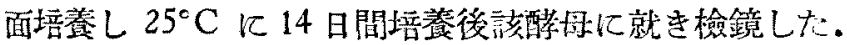

\begin{tabular}{|c|c|c|c|c|}
\hline 菌株符呫 & 球 & 槁圆 形 & 腸 请 形 & 摘 \\
\hline II 1 & $\begin{array}{c}80 \% \\
2.0 \sim 7.0 \% \\
4.0 \sim 6.0 \% \text { 多數 }\end{array}$ & $\begin{array}{c}20 \% \\
\text { 兩軸の差 } \\
2.5 \sim 1.0 \%\end{array}$ & & 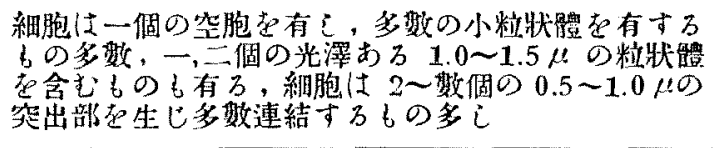 \\
\hline II 2 & $\begin{array}{c}50 \% \\
2.0 \sim 10.0 \\
(4.0 \sim 6.0) \text { 多数 }\end{array} \mid$ & $\begin{array}{l}50 \% \\
(4.0 \sim 60) \times \\
(6.0 \sim 8.0)\end{array}$ & & 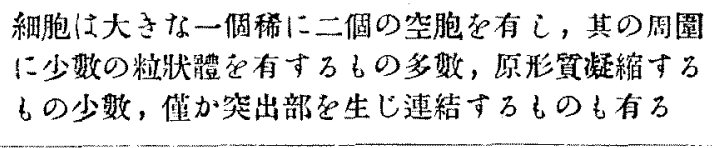 \\
\hline II 3 & $\begin{array}{c}40 \% \\
3.0 \sim 8.0\end{array}$ & $\begin{array}{l}60 \% \\
\text { 雨㽟の差 } \\
2.0 \sim 3.0\end{array}$ & & 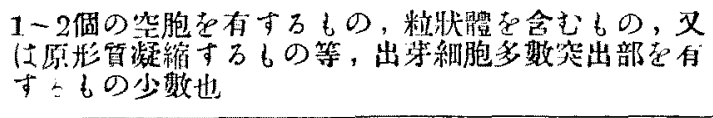 \\
\hline HI 4 & $\begin{array}{c}80 \% \\
2.5 \sim 7.5\end{array}$ & $\begin{array}{c}20 \% a \\
\text { 网辒の差 } \\
0.5 \sim 1.0\end{array}$ & & 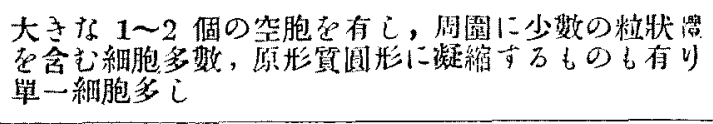 \\
\hline If 5 & $\begin{array}{c}70 \% \\
3.0 \sim 8.0\end{array}$ & $\begin{array}{l}30 \% \\
\text { 雨桠の差 } \\
1.5 \sim 2.5\end{array}$ & & 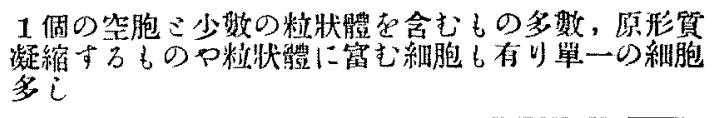 \\
\hline
\end{tabular}




\begin{tabular}{|c|c|c|c|c|}
\hline $\mathrm{H} \quad 6$ & $\begin{array}{l}90 \% \\
3.0 \sim 7.0\end{array}$ & $\begin{array}{l}10 \% \\
\text { 兩軸の䓓 } \\
0.5 \sim 1.0\end{array}$ & $\begin{array}{c}\text { (3.0 嚾少 } \\
(8.0 \sim 15.0) \times\end{array}$ & 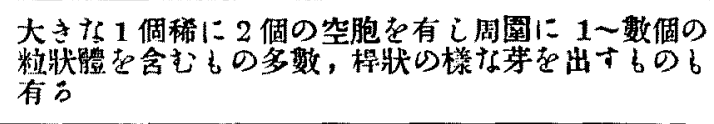 \\
\hline H 7 & $\left|\begin{array}{c}70 \% \\
3.0 \sim 6.0 \\
(4.0 \sim 5.0) \text { 多數 }\end{array}\right|$ & $\begin{array}{l}30 \% \\
\text { 兩軸 } 9 \text { 差 } \\
2.0 \text { 前後 }\end{array}$ & & 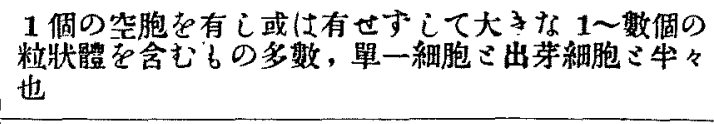 \\
\hline HI 8 & $\begin{array}{l}70 \% \\
3.0 \sim 7.0\end{array}$ & $\begin{array}{l}30 \% \\
\text { 雨軸の差 } \\
0.5 \sim 1.0\end{array}$ & & 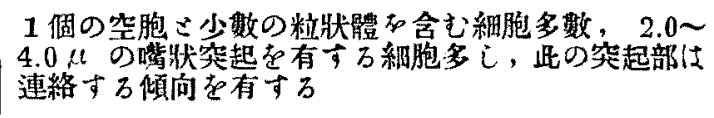 \\
\hline II 9 & $\begin{array}{l}20 \% \\
2.5 \sim 75\end{array}$ & $\begin{array}{l}80 \% \\
(2.0 \sim 3.5) \times \\
(3.0 \sim 5.0)\end{array}$ & & $\begin{array}{l}1 \text { 個の筀胞さ少数の粗狀體を含む細胞多数，單一細 } \\
\text { 胞多し }\end{array}$ \\
\hline II 10 & $2.0 \sim 6.0$ & & & $" \prime$ \\
\hline H 11 & $\begin{array}{l}60 \% \\
3.0 \sim 7.0\end{array}$ & $\begin{array}{l}40 \% \\
\text { 网軸の差 } \\
0.5 \sim 1.0\end{array}$ & & 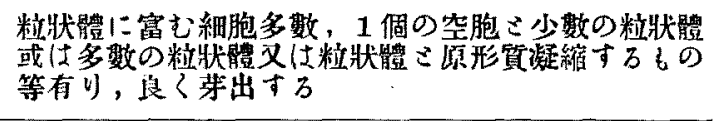 \\
\hline II 12 & $\mid \begin{array}{c}80 \% \\
3.0 \sim 6.0 \\
(4.0 \sim 5.0) \text { 多數 }\end{array}$ & $\begin{array}{l}10 \% \\
\text { 雨軸の差 } \\
0.5 \sim 1.0\end{array}$ & & 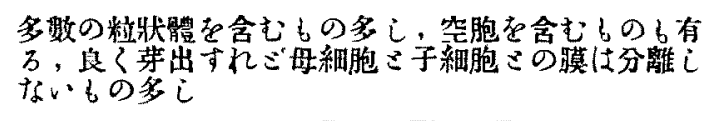 \\
\hline H 14 & $\begin{array}{c}90 \% \\
2.5 \sim 8.0 \\
(6.0 \sim 7.0) \text { 多奻 }\end{array}$ & 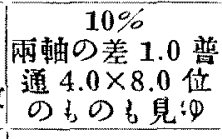 & & 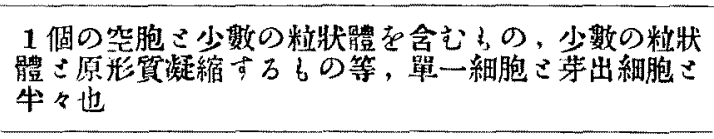 \\
\hline H 15 & $\mid \begin{array}{c}90 \% \\
3.0 \sim 9.0 \\
(4.0 \sim 5.0) \text { 多数 }\end{array}$ & $\begin{array}{l}10 \% \\
\text { 雨軸の差 } \\
1.0 \sim 1.5\end{array}$ & & 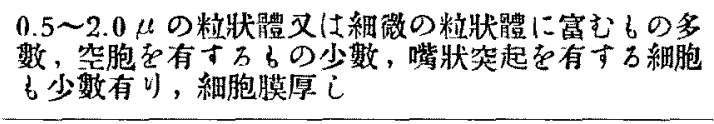 \\
\hline II 16 & $\mid \begin{array}{c}30 \% \\
3.0 \sim 7.0 \\
(4.0 \sim 5.0)\end{array}$ & $\begin{array}{l}70 \% \\
(3.0 \sim 6.0) \times \\
(4.0 \sim 7.0)\end{array}$ & & 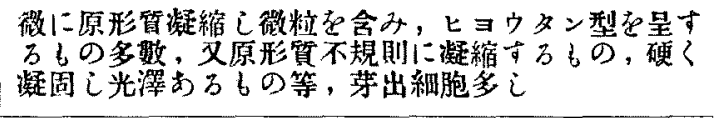 \\
\hline II 17 & 僅少 $1.5 \sim 4.0$ & $\begin{array}{l}80 \% \\
(1.5 \sim 3.0) \times \\
(2.0 \sim 5.0)\end{array}$ & $\begin{array}{c}20 \% \\
(1.5 \sim 3.5) \times \\
(4.0 \sim 8.0)\end{array}$ & 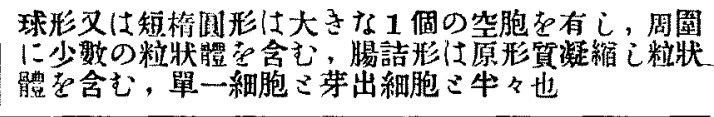 \\
\hline II 18 & $\prime \prime$ & " & " & 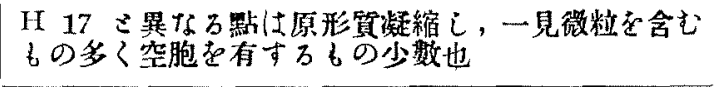 \\
\hline H 19 & $\mid \begin{array}{c}3.0 \sim 6.0 \\
(4.0 \sim 5.0)\end{array}$ & & & 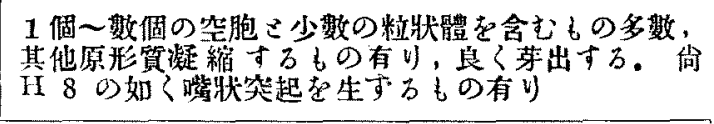 \\
\hline II 20 & $\begin{array}{l}3.0 \sim 8.0 \\
6.0 \text { 前淩多i }\end{array}$ & & & 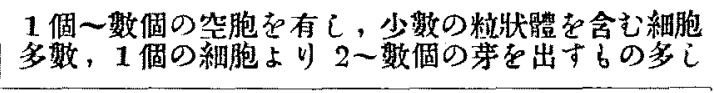 \\
\hline II 21 & $2.0 \sim 8.0$ & & & 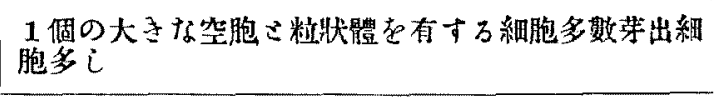 \\
\hline If 22 & $2.0 \sim 5.0$ & & & 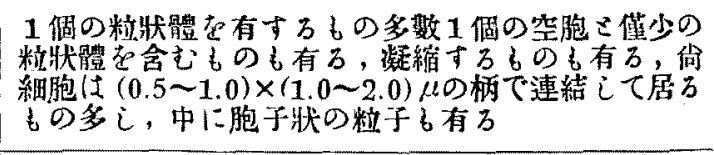 \\
\hline II 23 & $\begin{array}{c}3.0 \sim 6.5 \\
(4.0 \sim 5.0)\end{array}$ & & & 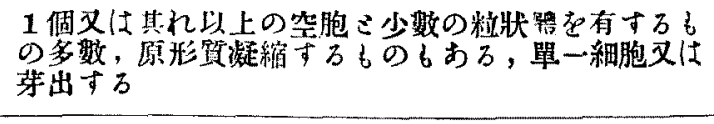 \\
\hline II 24 & $\begin{array}{c}3.0 \sim 8.0 \\
(6.0 \sim 7.0)\end{array}$ & & & 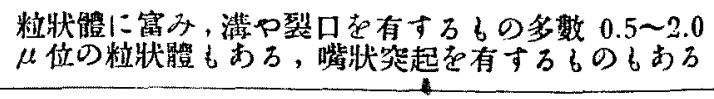 \\
\hline
\end{tabular}




\begin{tabular}{|c|c|c|c|c|}
\hline II 25 & $\begin{array}{l}3.0 \sim 7.0 \\
5.0 \text { 前後多数 }\end{array}$ & & & 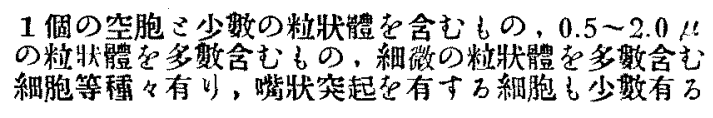 \\
\hline II 26 & $\mid \begin{array}{c}3.0 \sim 8.0 \\
(3.0 \sim 4.0)\end{array}$ & $\cdots$ & & 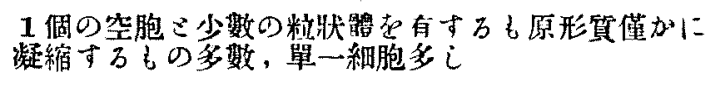 \\
\hline H 28 & & $\begin{array}{c}80 \% \\
(1.5 \sim 2.5) \times \\
(2.5 \sim 6.0)\end{array}$ & $\begin{array}{c}20 \% \\
(0.8 \sim 1.5) \times \\
(2.0 \sim 10.0)\end{array}$ & 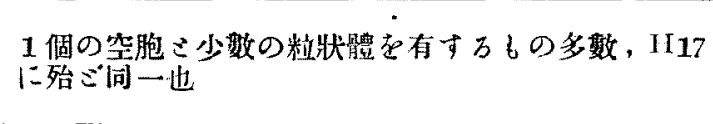 \\
\hline H 31 & $\begin{array}{c}2.0 \sim 8.0 \\
(4.0 \sim 5.0)\end{array}$ & & $\begin{array}{c}\text { 僅少 } \\
(2.0 \sim 3.0) \times \\
(20.0 \sim 30.0)\end{array}$ & 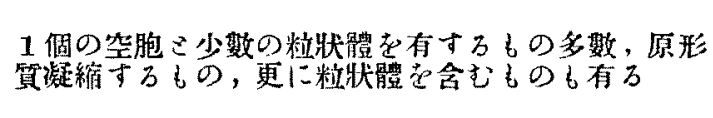 \\
\hline H 32 & $\begin{array}{l}20 \% \\
3.0 \sim 7.0\end{array}$ & $\begin{array}{c}80 \% \\
\text { 兩軸の羙 } 1.0 \text { 位 } \\
(3.0 \sim 6.0) \times \\
(5.0 \sim 9.0)\end{array}$ & & 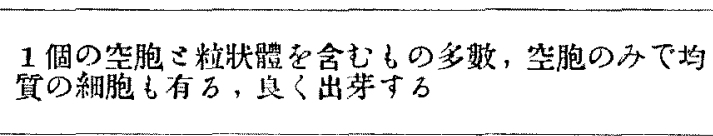 \\
\hline H 33 & $\begin{array}{c}20 \% \\
2.0 \sim 6.0\end{array}$ & $\begin{array}{c}80 \% \\
(2.0 \sim 4.0) \times \\
(4.0 \sim 7.0)\end{array}$ & & 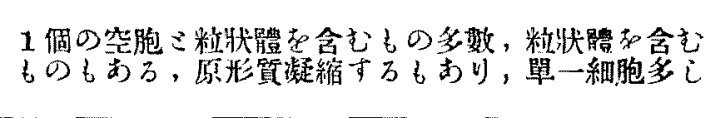 \\
\hline H 34 & $\begin{array}{ll}50 \% \\
4.0 \sim 9.0\end{array}$ & $\begin{array}{l}50 \% \\
\text { 兩軸の差 } \\
1.0 \text { 位 }\end{array}$ & & 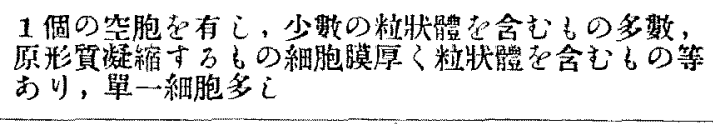 \\
\hline 1135 & $\begin{array}{l}90 \% \\
2.0 \sim 7.0\end{array}$ & $\begin{array}{l}10 \% \\
\text { 兩軸の差 } \\
1.0-1.5\end{array}$ & & 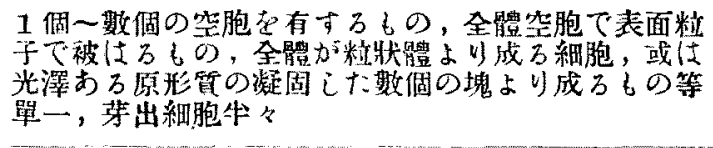 \\
\hline H 36 & $\begin{array}{l}20 \% \\
2.0 \sim 6.0\end{array}$ & $\begin{array}{l}80 \% \\
(2.0 \sim 5.0) \times \\
(5.0 \sim 6.0)\end{array}$ & & 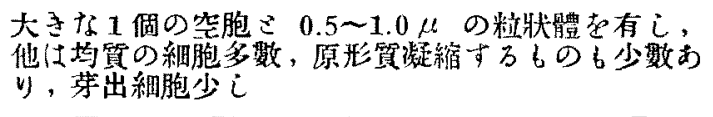 \\
\hline II 37 & $\mid \begin{array}{c}50 \% \\
2.0 \sim 6.0 \\
(3.0 \sim 4.0) \text { 多数 }\end{array}$ & $\begin{array}{l}50 \% \\
\text { 爾軸の差 } \\
1.0 \sim 1.5\end{array}$ & & 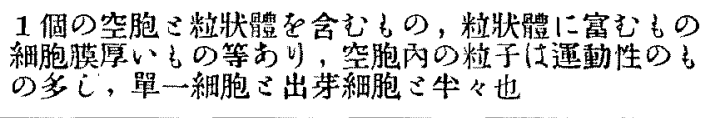 \\
\hline H 122 & $1.5 \sim 4.5$ & $\begin{array}{r}(2.0 \sim 4.0) \times \\
\quad(2.5 \sim 5.0)\end{array}$ & & 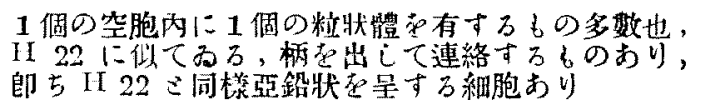 \\
\hline
\end{tabular}

2. 液體培養。

(1) 稳 汁

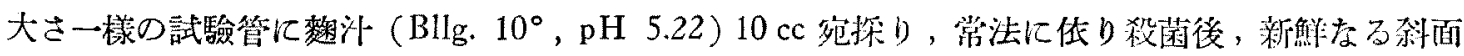

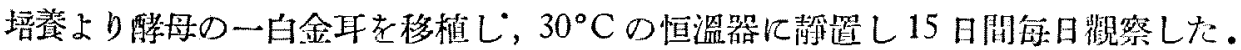

\begin{tabular}{|c|c|c|c|c|c|c|c|c|c|c|c|}
\hline \multirow{2}{*}{ 简符號 } & \multicolumn{4}{|c|}{ 氟 } & \multicolumn{2}{|l|}{ 泡 } & \multicolumn{2}{|l|}{ 撥 } & \multicolumn{2}{|l|}{ 生 } & \multirow{2}{*}{ 浭濁，皮腹，島嶼，酵四輸等 } \\
\hline & i日 & 2日 & 3日 & 4 日 & 5 日 & 6日 & 7 日 & 8 日 & 9 日 & 10 日 11 日 & \\
\hline H 1 & & + & + & + & + & \pm & & & & & 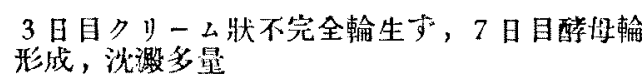 \\
\hline H 2 & & & + & + & + & + & + & + & \pm & & 泌溊多星 \\
\hline H 3 & & + & H & \# & $\#$ & $\#$ & + & & & & 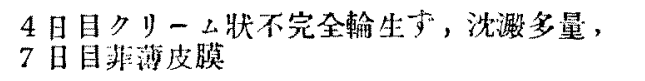 \\
\hline II 4 & & + & + & + & + & \pm & & & & & 15日日不規則不完全輪生す，沈䬦多量 \\
\hline II 5 & & + & + & H & + & \pm & & & & & 11 \\
\hline II 6 & & & + & + & + & \pm & & & & & $\prime \prime$ \\
\hline
\end{tabular}




\begin{tabular}{|c|c|c|c|c|c|c|c|c|c|c|c|c|}
\hline II 7 & & & +1 & $\#$ & + & + & + & + & + & & & 15日目不規則不完全翰生ず, 沙澱多量 \\
\hline 8 & + & th & \# & \# & + & \pm & & & & & & 15日目賏弱なる不完全輪生ず \\
\hline H 9 & & + & + & + & \# & + & + & + & & & & 沈測多量 \\
\hline H 10 & & + & + & H & $\#$ & \# & $H$ & \# & \# & & & 8日目クリーム狀不党全輪生す，沈測多量 \\
\hline HI 11 & & + & + & H & \# & + & + & + & & & & " \\
\hline II 12 & & & + & + & + & + & + & + & + & & & 15日目不規則不完全輸生す，沈激多量 \\
\hline II 14 & & + & + & + & $t^{-}$ & \# & + & + & + & & & 沈淝多量 \\
\hline H 15 & & + & + & 世 & \# & H & + & \pm & & & & 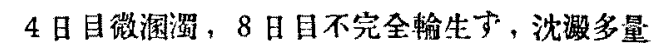 \\
\hline II 16 & & & \pm & & & & & & & & & 8 日目餐弱なる不完全輪生ず，沈敗多量 \\
\hline I 17 & & H & + & + & + & + & + & + & \pm & & & 4日目酵拇輸形成，洗激多量 \\
\hline HI 18 & & \# & H & + & + & + & + & + & \pm & & & $n$ \\
\hline II 19 & & + & + & + & $\#$ & + & + & + & \pm & & & 8 日目不規则不完全輪生ず, 沈澱多量 \\
\hline II 20 & & + & + & + & \# & + & + & + & \pm & & & 4日目クリーム狀不完全輪生す。, 沛激多量 \\
\hline H 21 & & \pm & \pm & + & $\#$ & + & + & + & + & \pm & - & 8 日目クリーム狀不完全輪生す，沈漴多量 \\
\hline If 22 & & & & & & & & & & & & 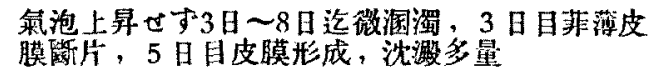 \\
\hline II 23 & & & + & + & + & + & + & + & + & & & 8日目不規則不完全輪生す，沈澱多量 \\
\hline H 24 & & & + & + & + & + & + & + & + & & & $\prime \prime$ \\
\hline II 25 & & + & 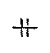 & H- & H & + & + & + & & & & $"$ \\
\hline H 26 & & + & + & \# & H & H & H & $\#$ & $H$ & \pm & - & 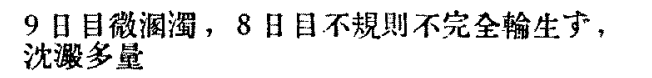 \\
\hline II 28 & & \# & H & $H$ & $\#$ & + & + & + & + & & & 4 日目酲檕輸形成，洗測多量 \\
\hline II 31 & & + & + & + & + & \pm & & & & & & 沈測多量 \\
\hline II 32 & & + & $\ddot{H}$ & $\#$ & H & \pm & & & & & & 4日目不規則不完全輸生す，沈測多量 \\
\hline II 33 & & $t_{t}^{\prime}$ & $t^{*}$ & + & + & + & + & + & & & & 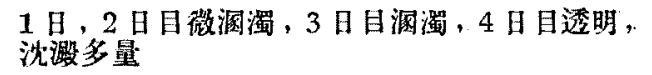 \\
\hline If 34 & & & + & + & + & \# & \# & H & + & \pm & - & 15日目資弱不完全輪生ず，沈涺多量 \\
\hline H 35 & & & & & & & & & & & & 氮泡上昇せず，發育痕跡 \\
\hline II 36 & + & H & + & + & & & & & & & & 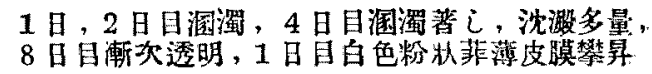 \\
\hline II 37 & & & & & \pm & + & + & + & + & & & 沈澱多量 \\
\hline H 122 & & & & & & & & & & & & 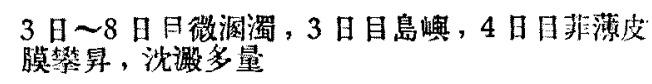 \\
\hline
\end{tabular}

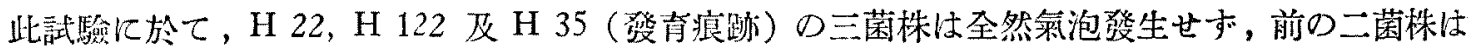

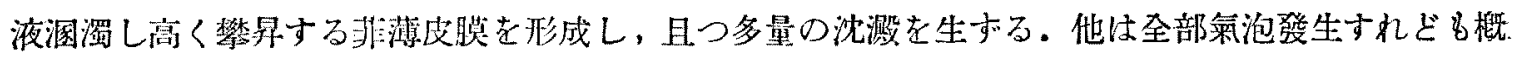
して酸酵力弱くその力緩慢にして 5 日～10 日間繼續する。この中 H 2，H 9，H 14，H 31，H 33， H 37 の 6 菌株は罚に沈搌のみを生じ，H 17，H 18，H 28 の3菌株は醉母輸を良く形成し，殘り

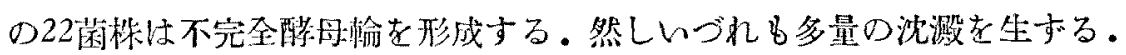

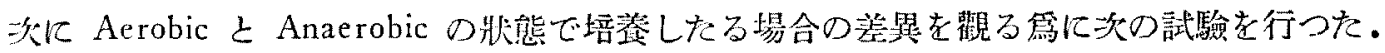

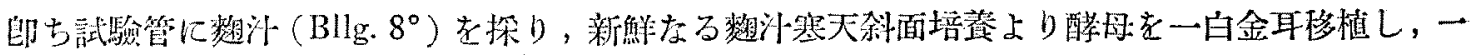

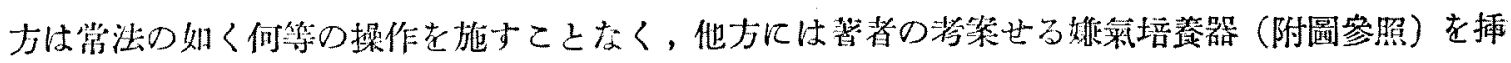
入し，KOH 及び Pyrogallol の各 15 20\% の液を夫夫 $10 \mathrm{cc}$ 注入混和し，一望夜溫室に放置後

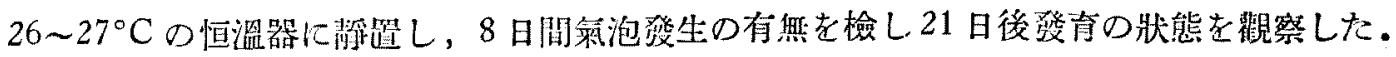




\begin{tabular}{|c|c|c|c|c|c|c|c|c|c|c|c|c|c|c|c|c|}
\hline \multirow{2}{*}{ 菌株符號 } & \multicolumn{4}{|c|}{ 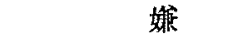 } & \multicolumn{2}{|l|}{ 氣 } & \multicolumn{2}{|l|}{ 性 } & \multicolumn{5}{|c|}{ 好 } & \multicolumn{2}{|c|}{ 氣 } & 性 \\
\hline & 2 日 & 3日 & 4日 & 5 日 & $6 日$ & 7日 & 8 日 & $21 日$ & 2 日 & 3 日 & 4 日 & 5 日 & 6日 & 7 日 & 8 日 & $21 日$ \\
\hline H 1 & & \pm & + & + & H & H & + & 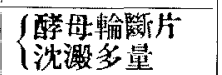 & + & + & + & + & + & $H$ & HI & $\left\{\begin{array}{l}\text { 䤕母檢形成 } \\
\text { 沘激多量 }\end{array}\right.$ \\
\hline H 2 & & \pm & + & + & + & + & \pm & 沈測多星 & & + & + & + & + & + & & 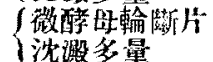 \\
\hline H 3 & & & & & & & & 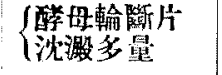 & & & & & + & $\#$ & + & 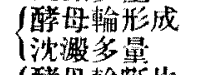 \\
\hline $\mathrm{H} 4$ & & \pm & + & + & + & + & + & $" \prime$ & \pm & + & $H$ & $\#$ & + & + & + & 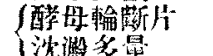 \\
\hline $\mathrm{H} 5$ & & & & & & & + & " & & & + & + & + & \pm & & 11 \\
\hline $\mathrm{H} \quad 6$ & & & & & & & & $\prime \prime$ & & & 1 & + & + & \pm & & " \\
\hline H 7 & & & & & & & & 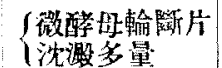 & & & + & + & + & \pm & & " \\
\hline H 8 & & + & + & + & + & + & & 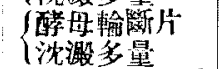 & & \pm & + & + & + & & & " \\
\hline II 9 & & & & & \pm & & & 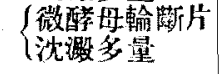 & & & & \pm & & & & 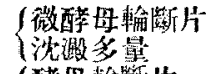 \\
\hline H 10 & & \pm & & & & & & 泝漖多量 & & \pm & + & + & + & + & \pm & 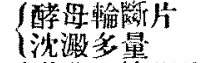 \\
\hline H 11 & & & & & & & & & $H$ & ti & $H$ & + & + & + & & 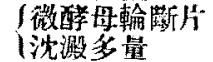 \\
\hline H 12 & & & & & & & + & 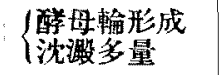 & + & + & + & + & + & + & & $\left\{\begin{array}{l}\text { 酝坶签形成 } \\
\text { 沈㴬多量 }\end{array}\right.$ \\
\hline H 14 & & & & & & & & 沈激多量 & & & \pm & & & & & 沈敗多量 \\
\hline H 15 & & & & & & & & 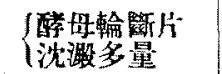 & & & & & & \pm & & 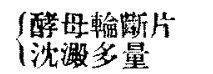 \\
\hline $\mathrm{H} 16$ & & & & & & & & 沈濒多量 & & & & & & & & 沈溉多量 \\
\hline H 17 & & & & + & $\#$ & \# & H & 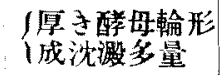 & & & + & + & \pm & \pm & \pm & 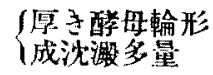 \\
\hline HI 18 & & & & $H$ & + & th & $H$ & " & & & & & & \pm & & " \\
\hline H 19 & & & & & & & & 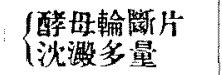 & & & + & + & + & + & & \\
\hline $\mathrm{H} 20$ & & & & \pm & & & & & & & & & & & & 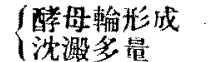 \\
\hline H 21 & & & & & & + & + & $\left\{\begin{array}{l}\text { 酵母輸形成 } \\
\text { 沈激多量 }\end{array}\right.$ & & & \pm & + & + & + & + & 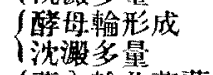 \\
\hline H 22 & & & & & & & & " & & & & & & & & 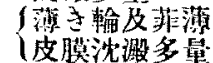 \\
\hline $\mathrm{H} 23$ & & & & & & & & 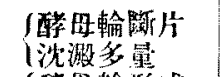 & & & & & & + & & 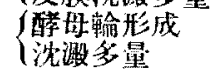 \\
\hline H 24 & \pm & $\frac{1}{t}$ & + & + & + & + & & 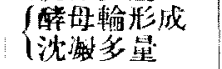 & $t$ & + & H & $\#$ & + & $H$ & \# & " \\
\hline H 25 & & & + & + & $\dot{T}$ & + & + & 沈濒多量 & & & + & + & + & + & \pm & 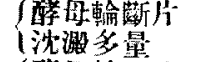 \\
\hline H 25 & & & H & + & + & + & + & 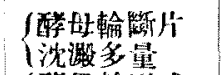 & & H & th & \# & + & + & \pm & 醇好榆形成 \\
\hline $\mathrm{H} 28$ & & $H$ & \# & $H$ & + & + & + & 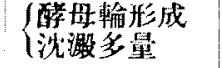 & & + & + & + & + & \pm & \pm & 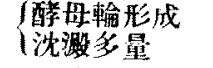 \\
\hline H 31 & & & & & & & & 沈澱多量 & & \pm & & & & & & 湤澱多量 \\
\hline H 32 & & & & & & & & 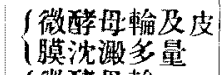 & & & & & & + & & 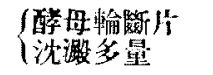 \\
\hline H 33 & H & + & th & $\#$ & H & \# & + & 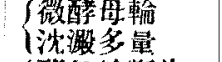 & + & + & + & + & + & + & & 沈㵊多量 \\
\hline HI 34 & & & & & & & + & 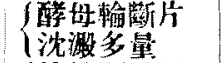 & + & + & + & H & + & + & + & 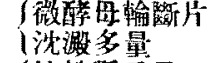 \\
\hline $\begin{array}{l}\text { H } 35 \\
\text { H } 36\end{array}$ & \pm & \pm & + & & & & & 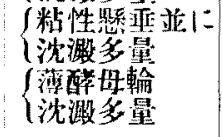 & + & $\ddot{H}$ & + & & & & & 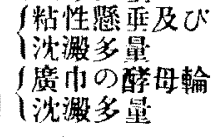 \\
\hline H 37 & & & & & & & & 沈澱多量 & & & & & & & & 沈㴬多量 \\
\hline H 122 & & & & & & & & H.22 に园し & & & & & & & & H22 に间じ \\
\hline
\end{tabular}


此試驗の結果に依れば，好氣性の場合割合良く黄色乃至黃橙色の酵母輪を形成し，之に反し嫌氣 性の場合では H 22, H 122 を除き他汢悉く酵母輸の形成稍々劣り, 而もその色は乳白色乃至淡黃 色である．猶沈澱生成量は例外なく好氣性の場合が婙氣性の場合より多い，又嫌氣性では氣泡發生 せざるものが相當多い。

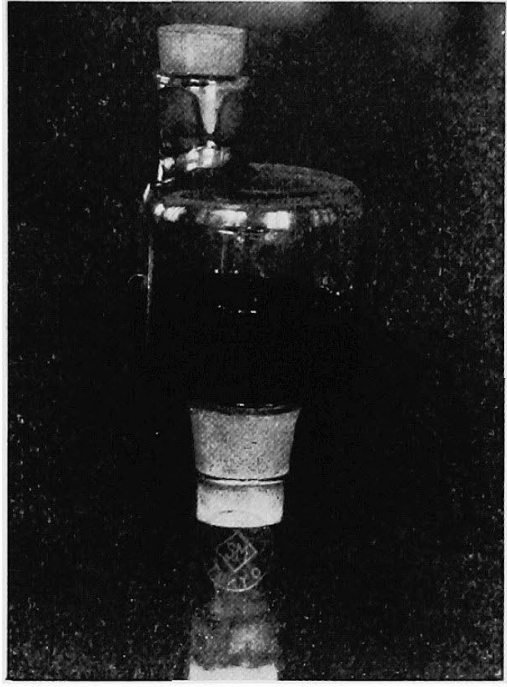

婙氣用培盖器（略々筫物大）
踭氯用培養器略圖

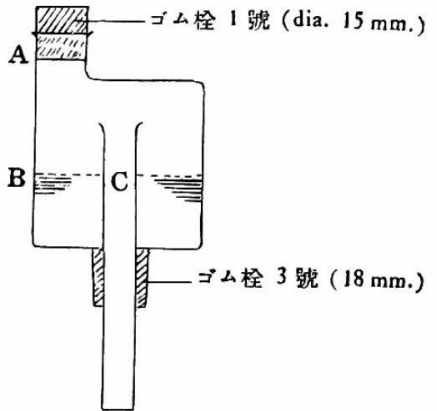
A : 直徑 $1.5 \mathrm{~cm}$, 高さ $1.5 \mathrm{~cm}$
$\mathrm{B}$ : 㨁徑 $4.0 \mathrm{~cm}$, 高さ $3.5 \mathrm{~cm}$
$\mathrm{C}$ : 直徑 $1.0 \mathrm{~cm}$, 高さ $6.0 \mathrm{~cm}$

（2）味噌汁培養.

$500 \mathrm{~g}$ の “注まれ白味噲”に $2 \mathrm{~L}$ の蒸溜水を加へ時々振璗して 5 時間浸出後，滤紙にて滤過した る液を $\mathrm{A}$ とし， $\mathrm{A}$ 液 $800 \mathrm{cc}$ を 2 個の膀胱に探り $1 \mathrm{~L}$ の蒸溜水を滿せる beaker 中に懸垂し 10〜 $12^{\circ} \mathrm{C}$ に 40 時間透析し該液 $800 \mathrm{cc}$ 老大型蒸發血に探り Water-bath 上にて蒸發し約 $200 \mathrm{cc}$ となし たる後涗過して C 液 $(200 \mathrm{cc})$ とす.更に 40 時間同樣に處理して D 液を得る.膀胱內に殘留せる液 (1050 cc) は蒸發して B 液 $(400 \mathrm{cc})$ とす。

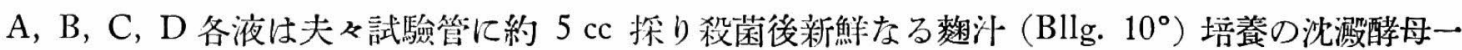
白金耳を移植し $30^{\circ} \mathrm{C}$ に 8 日間培養して覗察した。

猶 $\mathrm{A}, \mathrm{B}, \mathrm{C}, \mathrm{D}$ 各液つ糖分, 粗蛋白, 食監, 灰分, $\mathrm{pH}$ 等は次の如し。

\begin{tabular}{|c|c|c|c|c|c|}
\hline & 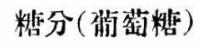 & 粗蛋白質 & 食監 & 分 & $\mathrm{pH}$ \\
\hline A 液 & 4.305 & 1.624 & 2.061 & 2.182 & 4.73 \\
\hline B 液 & 1.790 & 1.465 & 0.794 & 1.122 & 4.35 \\
\hline C液 & 6.855 & 2.226 & 3.608 & 3.808 & 4.46 \\
\hline D液 & 3.280 & 1.340 & 1.753 & 1.810 & 4.38 \\
\hline
\end{tabular}

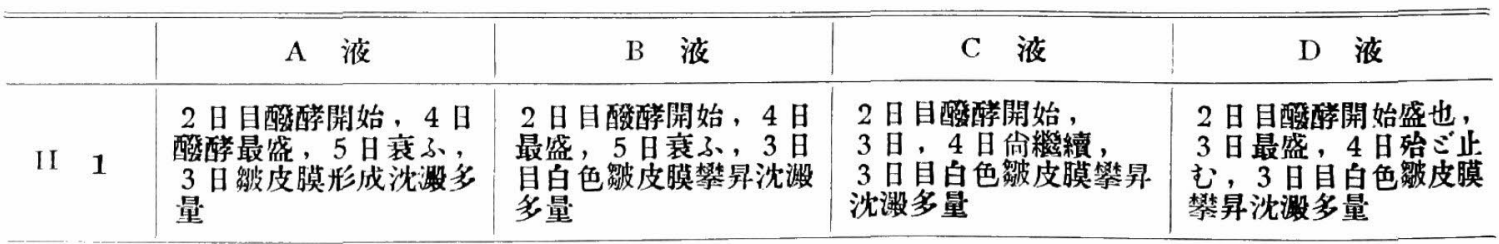




\begin{tabular}{|c|c|c|c|c|}
\hline II 2 & 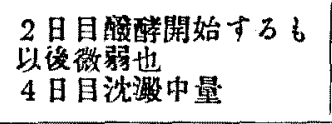 & 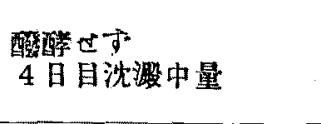 & 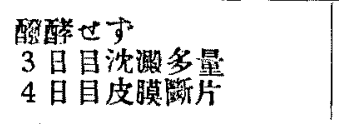 & 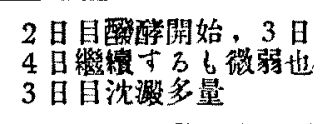 \\
\hline $\mathrm{H} 3$ & 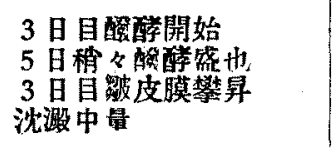 & 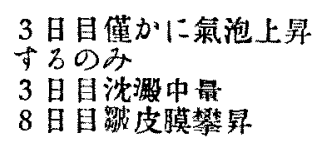 & 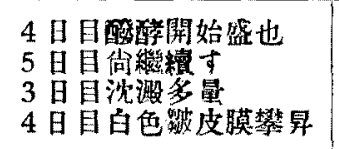 & 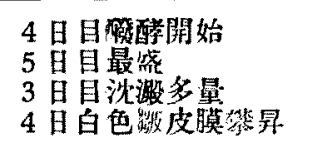 \\
\hline $\mathrm{H} 4$ & 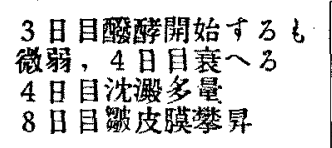 & 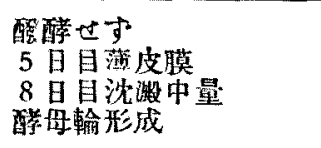 & 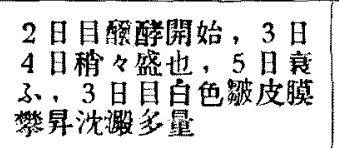 & 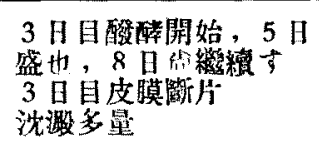 \\
\hline H 5 & 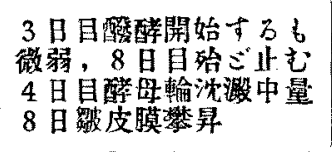 & 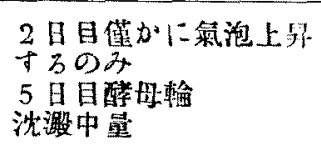 & 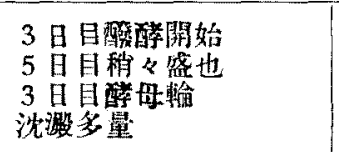 & 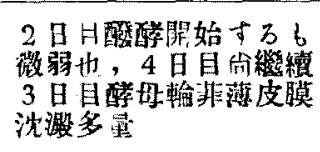 \\
\hline If 6 & 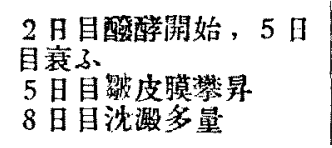 & 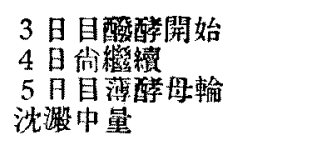 & 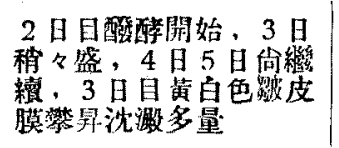 & 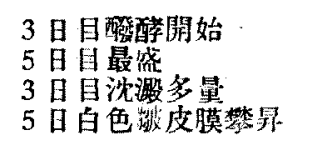 \\
\hline H 7 & 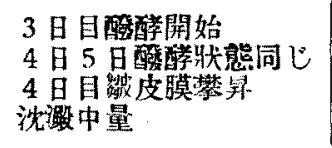 & 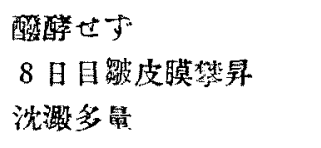 & $\div \mathrm{II} 6$ & 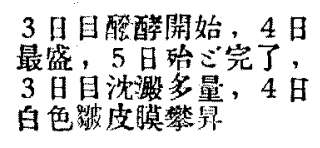 \\
\hline II 8 & $\begin{array}{l}3 \text { 日目僅加氣泡上显す } \\
8 \text { 日目沈溉中量 }\end{array}$ & 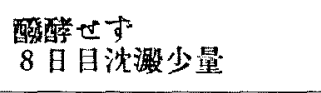 & 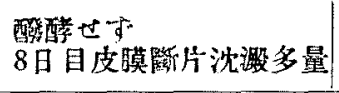 & 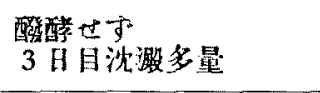 \\
\hline $\mathrm{H} \quad 9$ & 同上 & 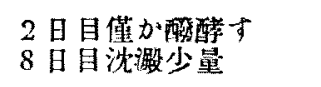 & $\doteqdot \mathrm{H} 8$ & $\doteqdot \mathrm{H} 8$ \\
\hline H 10 & 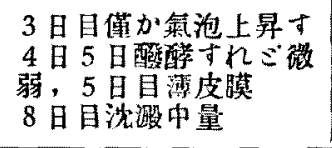 & 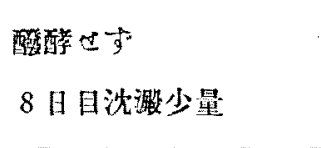 & 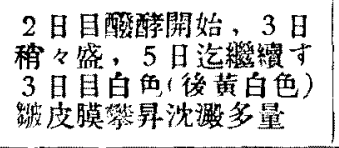 & 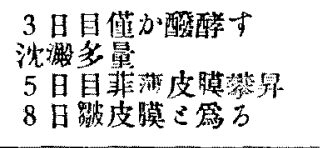 \\
\hline H 11 & 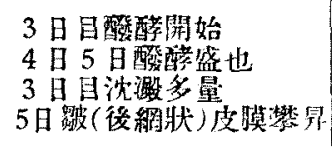 & 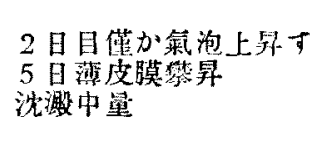 & 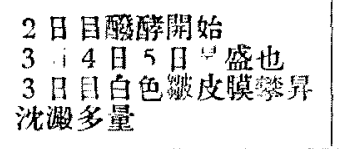 & 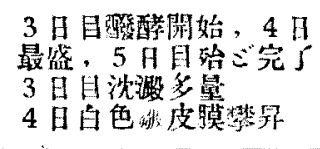 \\
\hline If 12 & 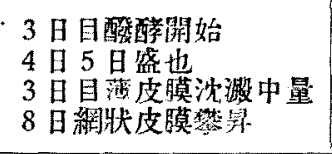 & 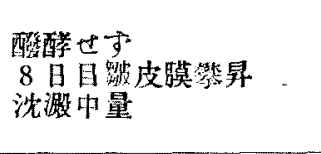 & 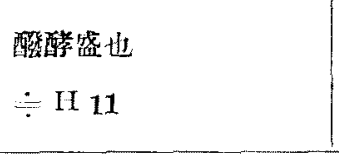 & 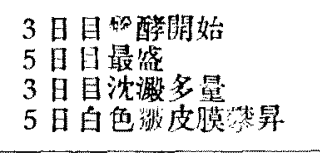 \\
\hline HI 14 & 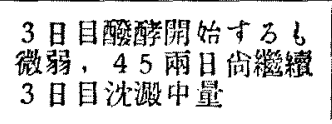 & 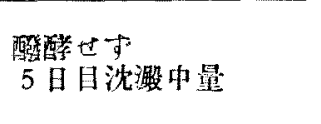 & 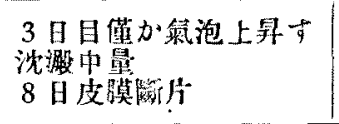 & 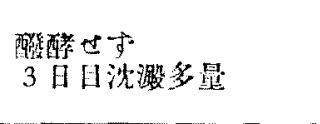 \\
\hline II 15 & 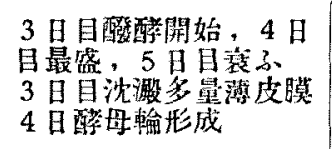 & 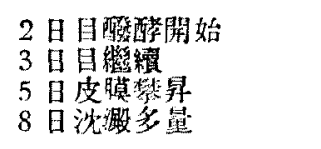 & 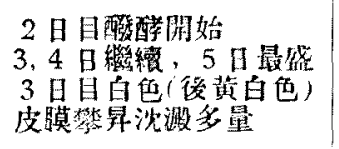 & 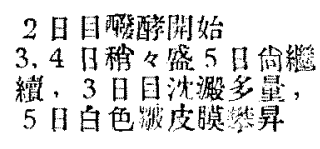 \\
\hline II 16 & 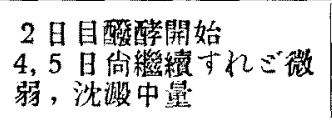 & $\begin{array}{l}\text { 酸醏せす } \\
4 \text { 日目沈測中量 }\end{array}$ & $\begin{array}{l}3 \text { 日目僅加瞪醉開始 } \\
\text { 沈溉中量 }\end{array}$ & 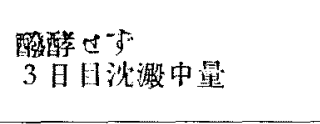 \\
\hline $\mathrm{H}_{17}$ & 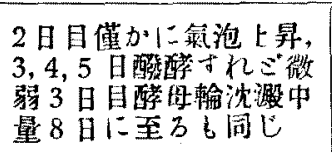 & 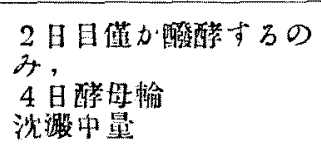 & 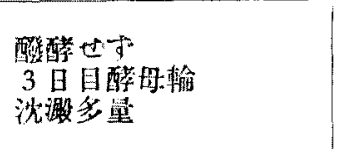 & 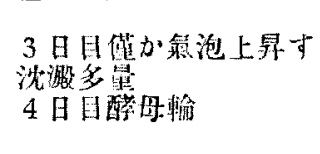 \\
\hline
\end{tabular}




\begin{tabular}{|c|c|c|c|c|}
\hline II 18 & 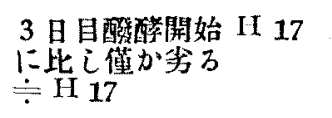 & 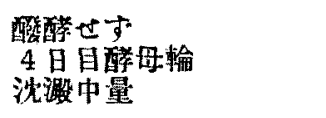 & 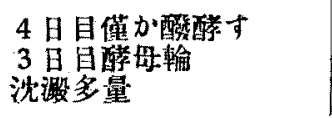 & $\therefore \mathrm{HI} 17$ \\
\hline H 19 & 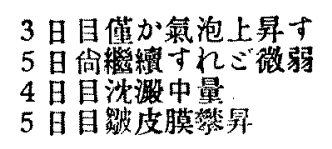 & 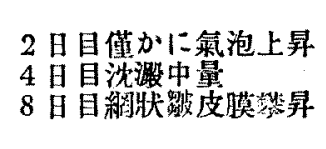 & 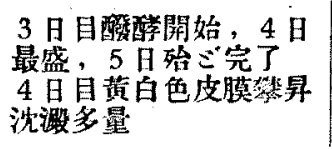 & 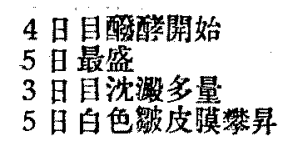 \\
\hline H 20 & $\begin{array}{l}\div \mathrm{H} 19 \\
8 \text { 日目解皮膜波狀 }\end{array}$ & $\begin{array}{l}\text { 櫭酵ぜず } \\
\div \text { H } 19\end{array}$ & 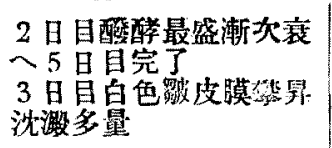 & 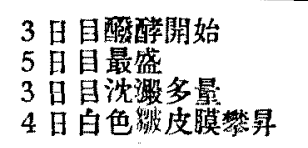 \\
\hline H 21 & 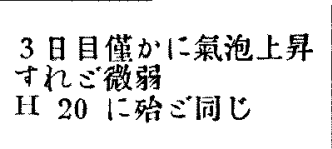 & 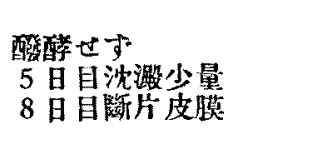 & 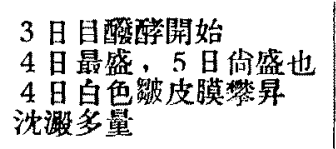 & 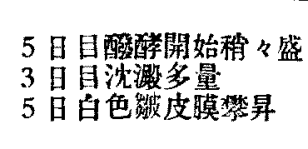 \\
\hline II 22 & 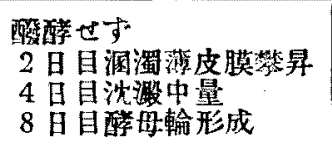 & 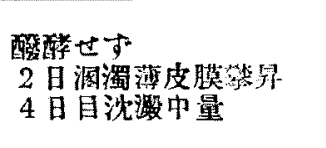 & 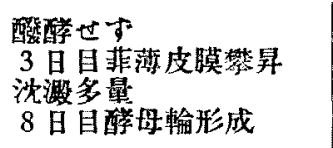 & 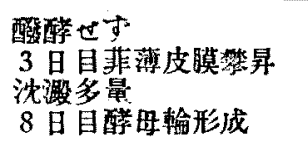 \\
\hline II 23 & 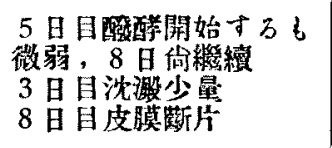 & $\begin{array}{l}\text { 酸酵せず } \\
4 \text { 日目沈測少星 }\end{array}$ & 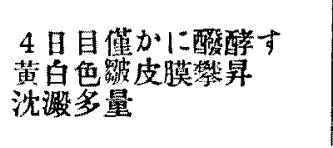 & 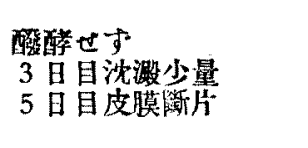 \\
\hline H 24 & 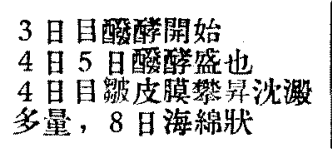 & 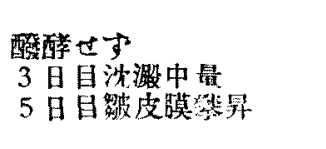 & 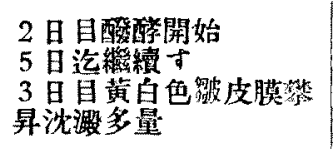 & 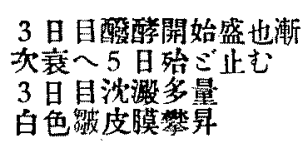 \\
\hline II 25 & $\because$ II 24 & 4 日目泌濒少量 & $\doteqdot \mathrm{H}_{24}$ & 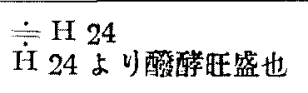 \\
\hline II 26 & $\begin{array}{l}3 \text { 日目酸醉開始 } \\
4,5 \text { 日盛也 } \\
\text { II } 24\end{array}$ & $\div$ II 25 & $\begin{array}{l}3,4 \text { 日秒外酻醭盛也 } \\
\div \text { II } 24\end{array}$ & 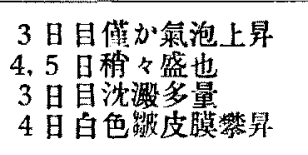 \\
\hline II 28 & 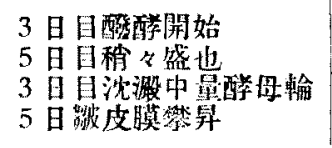 & 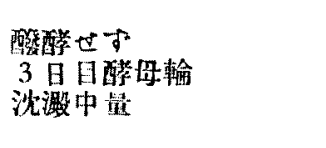 & 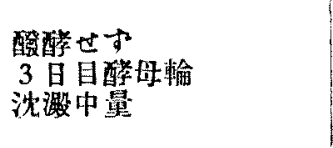 & 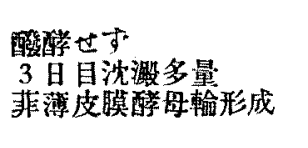 \\
\hline If 31 & 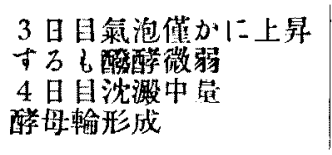 & $\begin{array}{l}3 \text { 日目沈澱少量 } \\
8 \text { 日目同じ }\end{array}$ & $\begin{array}{l}3 \text { 日目洗澱中量 } \\
8 \text { 日日皮膜綤片 }\end{array}$ & 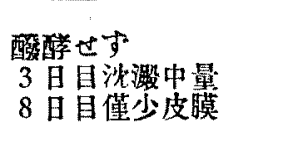 \\
\hline II 32 & 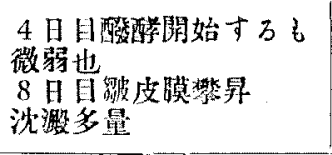 & $\begin{array}{l}3 \text { 日目沈澱少量 } \\
8 \text { 日目薄皮膜 }\end{array}$ & 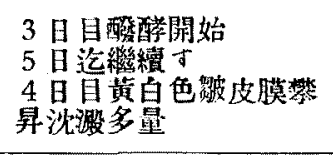 & 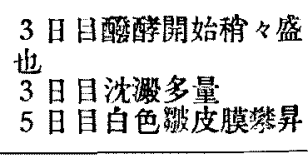 \\
\hline II 33 & 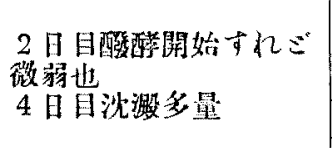 & $\doteqdot$ II 31 & $\begin{array}{l}2 \text { 日日僅加氮泡上昇 } \\
3 \text { 日日沈瀿多量 }\end{array}$ & 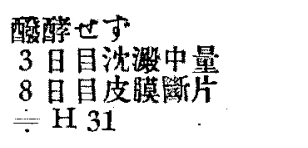 \\
\hline JI 34 & 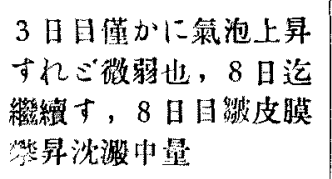 & 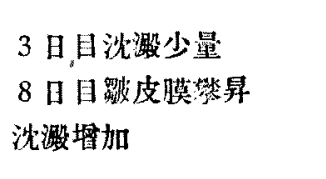 & 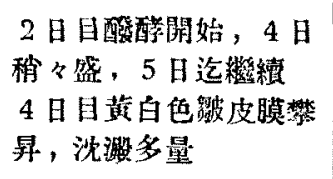 & 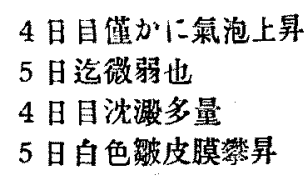 \\
\hline
\end{tabular}




\begin{tabular}{|c|c|c|c|c|}
\hline H 35 & 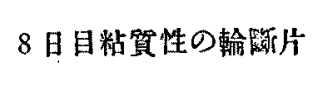 & 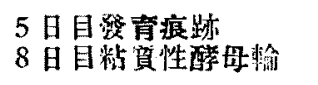 & 8 日目沈漫痕跡 & 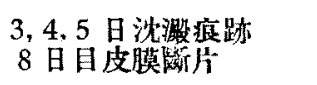 \\
\hline II 122 & 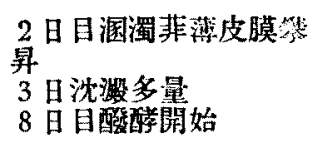 & 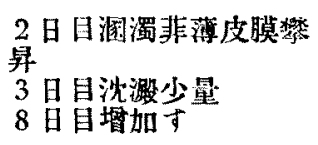 & 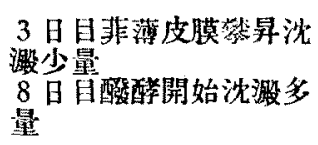 & 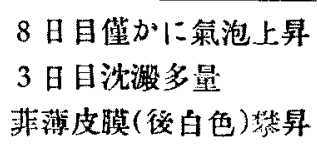 \\
\hline
\end{tabular}

味噲汁は良い培養基である。A 液は勿論 $\mathrm{C}$ 液， $\mathrm{D}$ 液に於ても其の發育良好で， $\mathrm{B}$ 液の如き養分稀

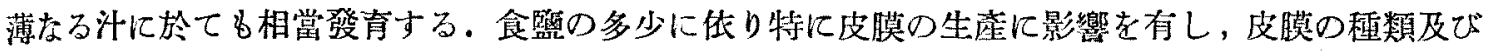

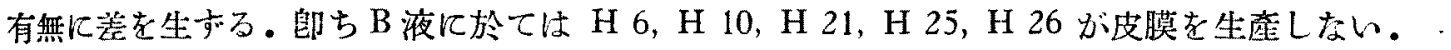

(3) 㢡 油 堛 養.

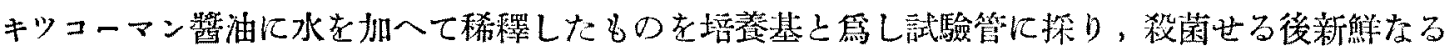

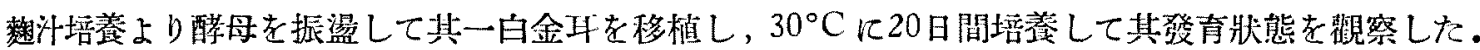

\begin{tabular}{|c|c|c|c|c|c|c|}
\hline & \multicolumn{3}{|c|}{ 醬油 $1+$ 蒸镏水 3} & \multicolumn{3}{|c|}{ 獎油 $1+$ 蒸䬫水 1} \\
\hline & 3 日 & 日 & 20 & $3 \mathrm{H}$ & 7 日 & 20 \\
\hline H 1 & 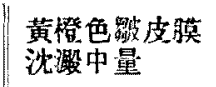 & 厚き殸さなる & $\begin{array}{l}\text { 酵母輪形成 } \\
\text { 沈澱多量 }\end{array}$ & 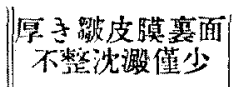 & 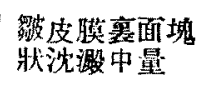 & 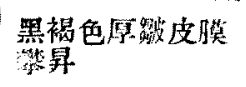 \\
\hline H 2 & 沈㹂少量 & 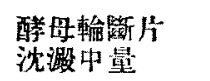 & $\begin{array}{l}\text { 酵母輸形成 } \\
\text { 沈測多量 }\end{array}$ & $\ldots$ & 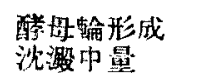 & $\begin{array}{l}\text { 黑褐色滑醉舟輪 } \\
\text { 沙潵中量 }\end{array}$ \\
\hline If 3 & 慜ごH 1 に同 & 殆ごHュに同 & 㱠ごリ 1 に同じ & 然ミ゙H1に同 & 列ごH 1に同 & 㕸ざH1に同し \\
\hline H 4 & 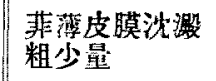 & 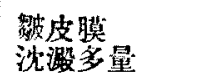 & 醇舴輪形成 & $\begin{array}{l}\text { 醋理輸断片 } \\
\text { 沈測僅少 }\end{array}$ & $r$ & $\prime \prime$ \\
\hline $\mathrm{H}^{\prime} 5$ & 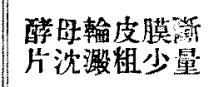 & $\begin{array}{l}\text { 醏母輸形成薄 } \\
\text { 度膜沈啣多量 }\end{array}$ & $"$ & 烈ぎH 1 に同 & " & " \\
\hline $\mathrm{H} \quad 6$ & 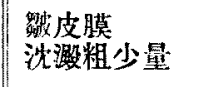 & H4に间じ & " & " & " & $" \prime$ \\
\hline II 7 & " & " & $\prime \prime$ & $\prime \prime$ & $" \prime$ & $\prime \prime$ \\
\hline II 8 & 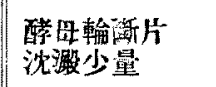 & 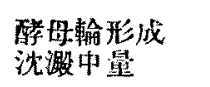 & 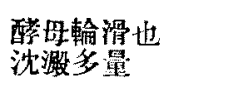 & 沈測少星 & 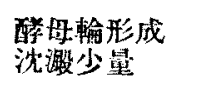 & 殆ミ゙H 2 に同し \\
\hline II 9 & 沈滶粗少量 & " & $" 1$ & 沈測侐少 & 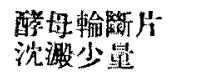 & $" \prime$ \\
\hline II 10 & 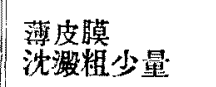 & 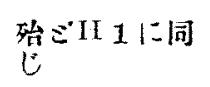 & 殆ごサI1に同じ & 烈ごル1に同 & 烈ジIIに同 & 硝ミ゙H $1 に$ に同じ \\
\hline II 11 & "I & " & $" \prime$ & $\begin{array}{l}\text { 䇥皮膜 } \\
\text { 洸澱少 }\end{array}$ & " & $\prime \prime$ \\
\hline II 12 & $\begin{array}{l}\text { 菲橮皮膜 } \\
\text { 沈溊粗少量 }\end{array}$ & " & " & $\begin{array}{l}\text { 薄皮膜 } \\
\text { 沈澱量 }\end{array}$ & $" \prime$ & $\prime \prime$ \\
\hline II 14 & 沈豬粗少量 & $\begin{array}{l}\text { 微酳田輸形成 } \\
\text { 沈澱中量 }\end{array}$ & 始ごIL 8に同し & 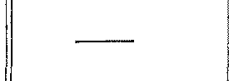 & 沈澱少筮 & 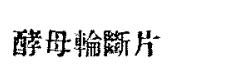 \\
\hline II 15 & $\begin{array}{l}\text { 薄皮膜 } \\
\text { 沈䬦中量 }\end{array}$ & 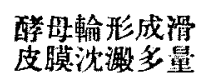 & $\prime \prime$ & 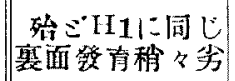 & 然ミ゙II 1 に同 & 殆ミ゙Hィに同し \\
\hline H 16 & 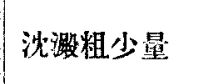 & 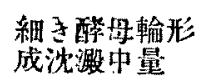 & " & 汹測僅少 & 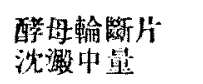 & 殆ごH 2 に同じ \\
\hline If 17 & $\begin{array}{l}\text { 醅舟輸断片 } \\
\text { 沈測粗少量 }\end{array}$ & $\begin{array}{l}\text { 酵母輸形成 } \\
\text { 淡激多量 }\end{array}$ & $\prime \prime$ & 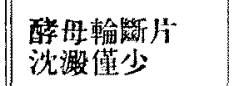 & 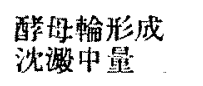 & 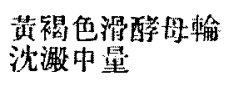 \\
\hline H 1.8 & $\begin{array}{l}\text { 醇母輸殆形成 } \\
\text { 沈澌粗少量 }\end{array}$ & " & " & 沈澱僅少 & " & " \\
\hline HI 19 & 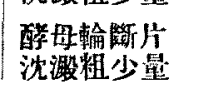 & 怨ごH 1 に同 & 殆ミ゙Hエに同し & 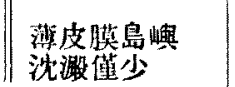 & 烈 & 砝ごII1に同じ \\
\hline
\end{tabular}




\begin{tabular}{|c|c|c|c|c|c|c|}
\hline II 20 & 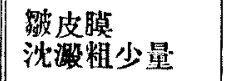 & 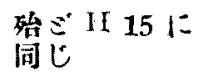 & 微薄醭坶輪形成 & 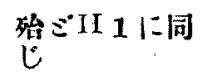 & 烈ミ゙リ1に同 & 珨ごH 1 に同り \\
\hline II 21 & $\begin{array}{l}\text { 㺃皮渵 } \\
\text { 沈擞粗少量 }\end{array}$ & $\begin{array}{l}\text { 烈气゙ H } 1 \text { に } \\
\text { 同じ }\end{array}$ & 喻ミ゙ル1に同じ & 10 & 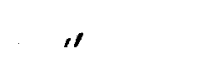 & " \\
\hline II 22 & $\begin{array}{l}\text { 菲薄皮膜 } \\
\text { 沈㹬㴽少量 }\end{array}$ & 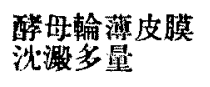 & 薄醇母輪 & $\begin{array}{l}\text { 菲薄皮膜 } \\
\text { 沈啭僅少 }\end{array}$ & $\begin{array}{l}\text { 灀皮膜 } \\
\text { 潹少量 }\end{array}$ & 砝ごI17に闰し \\
\hline $\mathrm{H} 23$ & 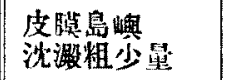 & $\begin{array}{l}\text { 殆气゙H1に } \\
\text { 同し }\end{array}$ & 殆ごH 1 に同し & 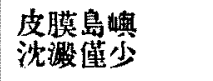 & 然ごII1に同 & 殆ミH１に同じ \\
\hline II 24 & 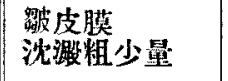 & $"$ & $" \prime$ & 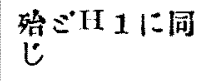 & " & " \\
\hline II 25 & $\begin{array}{l}\text { 跛皮膜 } \\
\text { 沈激中量 }\end{array}$ & " & $"$ & " & $" \prime$ & $"$ \\
\hline II 26 & $\prime \prime$ & $" \prime$ & $" 1$ & $" \prime$ & $\prime \prime$ & " \\
\hline II 28 & $\begin{array}{l}\text { 殑ミ゙II } 17 \text { に } \\
\text { 同じ }\end{array}$ & & 殆ごII 8 に同じ & 沈晸僅少 & 始ミ゙I[17に同 & 殆ミ゙17に同じ \\
\hline If 31 & 沈澱粗少量 & 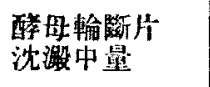 & $"$ & " & 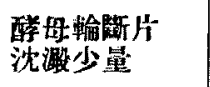 & $"$ \\
\hline 1132 & 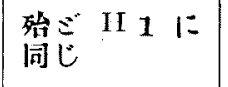 & 紴泌下す & 灌酵母軨 & 然こIIにに同 & 憵こ【1に同 & 殆ミ゙H 1に同し \\
\hline 11 33 & 沈殷粗少星 & 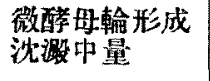 & $\begin{array}{l}\text { 微硣母輪 } \\
\text { 沈渐中量 }\end{array}$ & 沈殹僅少 & $\begin{array}{l}\text { 細 酵母輸 } \\
\text { 沈揤中量 }\end{array}$ & $\begin{array}{l}\text { 僅かに醇母輪形 } \\
\text { 成滑也 }\end{array}$ \\
\hline II 34 & $\begin{array}{c}\text { 薄皮膜䏢形成 } \\
\text { 始七洗彩粗尘 }\end{array}$ & $\begin{array}{l}\text { 殆ご II } 1 \text { に } \\
\text { 闹じ }\end{array}$ & 砝ミ゙H 1 に同じ & 劽ごH」に同 & 慜ごH $1 に$ に同 & 殆ごIエ1に同し \\
\hline II 35 & - & $\ldots$ & $\ldots$ & 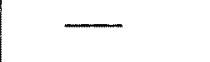 & - & - \\
\hline II 36 & 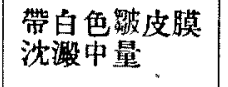 & 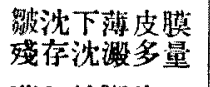 & 砝ジル1に同じ & $\begin{array}{l}\text { 蔪キリメン皮 } \\
\text { 膜沈測倠少 }\end{array}$ & 烈ごII 1 に同 & 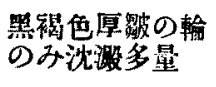 \\
\hline II 37 & 沈敗僅少 & 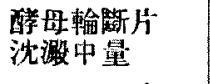 & 殄ミ゙H 8 に同じ & 沈測僅少 & 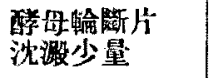 & 殆ざI133に同し \\
\hline II 122 & 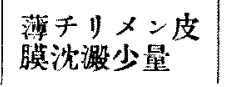 & $\begin{array}{l}\text { チリメン皮膜 } \\
\text { 沈海多量 }\end{array}$ & 殆ごII1に同し & $\begin{array}{l}\text { 翡薄皮膜 } \\
\text { 沈㴬嚾少 }\end{array}$ & $\begin{array}{l}\text { チリメン皮膜 } \\
\text { 沙洀中量 }\end{array}$ & $\begin{array}{l}\text { チリメン皮膜醏 } \\
\text { 四输沈澱多量 }\end{array}$ \\
\hline
\end{tabular}

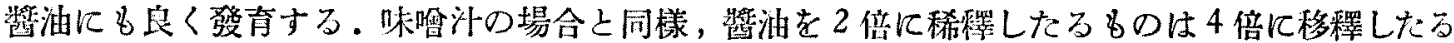
方上り皮膜の厚くなるものが多い。

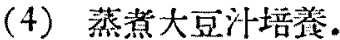

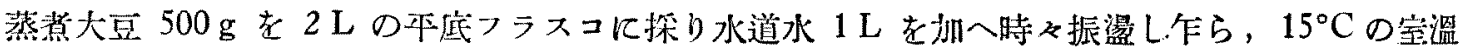

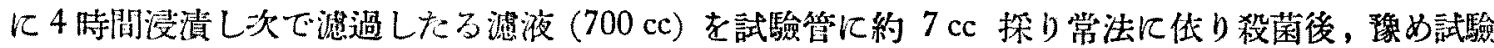

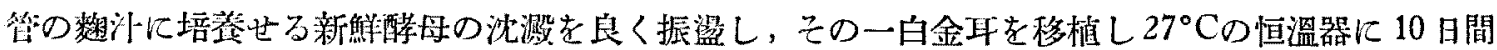

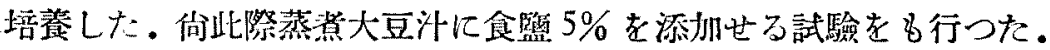

\begin{tabular}{|c|c|c|}
\hline 註： & 袮暑大亘汁の成分 & (100 cc 中) \\
\hline & 工キ又分 & $4.801 \%$ \\
\hline & 粗 蛋白質 & $1.523 \%$ \\
\hline & 浿敉糊等 & $1.578 \%$ \\
\hline & 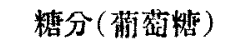 & $0.216 \%$ \\
\hline & pH & 5.27 \\
\hline
\end{tabular}

\begin{tabular}{|c|c|c|c|c|c|c|c|c|}
\hline \multirow{2}{*}{ 一菌株香駊 } & \multicolumn{4}{|c|}{ 蒸 尞 大亚 汁 } & \multicolumn{4}{|c|}{ 食監 $5 \%$ 添加蒸峚大亘汁 } \\
\hline & 沈 殸 & 酜母輸 & 㩲 & 要 & 沙淣 & 酵母輸 & 捅 & 要 \\
\hline II 1 & H & + & 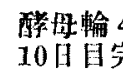 & & \# & + & 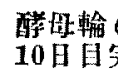 & \\
\hline
\end{tabular}




\begin{tabular}{|c|c|c|c|c|c|c|}
\hline $\mathrm{H} 2$ & + & + & $\begin{array}{l}\text { 醏母輪 6日目不完全 } \\
\text { 10日完全 }\end{array}$ & + & + & 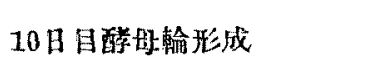 \\
\hline II 3 & + & - & & + & - & \\
\hline $\mathrm{H} \quad 4$ & + & $(t)$ & 10日目微醏母輸 & \# & + & 10日目酸母熸形成 \\
\hline II 5 & + & + & $\begin{array}{l}\text { 䤏母輸 6日目不完全 } \\
\text { 10日完全 }\end{array}$ & H & + & 同左 \\
\hline II 6 & + & + & $"$ & $\#$ & - & \\
\hline H 7 & H & + & 醭母輪 10 日目形成 & ti & + & 酸母輪10日目不完全 \\
\hline II 8 & $H$ & $(t)$ & 酽母輪10日目不完全 & H & + & " \\
\hline II 9 . & + & $(t)$ & 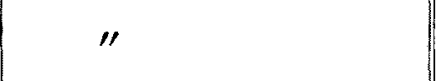 & H & + & $\begin{array}{l}\text { 䤏母輸6日目不完全 } \\
\text { 10日完全 }\end{array}$ \\
\hline H 10 & + & $(H)$ & $\prime \prime$ & $\#$ & + & 微酵母軨10日目形成 \\
\hline If 11 & $\#$ & + & 酵母䡒10日日形成 & H & + & 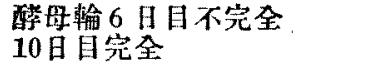 \\
\hline II 12 & $(t)$ & - & & + & - & \\
\hline If 14 & + & $(+)$ & 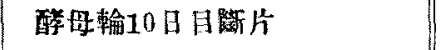 & + & - & \\
\hline If 15 & $\#$ & + & $\begin{array}{l}\text { 酵䑶輪6昌目不完全 } \\
\text { 10日完 }\end{array}$ & $\#$ & + & 酵母輸10日目形成 \\
\hline H 16 & \# & + & " & $H$ & $(\oplus)$ & 同上路片 \\
\hline If 17 & 册 & + & 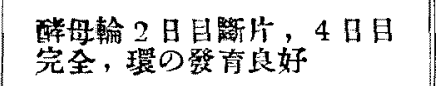 & 册 & + & 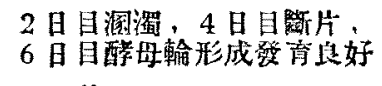 \\
\hline H 18 & 世 & + & ") & 册 & + & \\
\hline If 19 & $(t)$ & - & & + & - & \\
\hline If 20 & $H$ & + & $\begin{array}{l}\text { 醭母輸6日目不完全 } \\
10 \text { 完全 }\end{array}$ & \# & $(+)$ & 同左 \\
\hline II 21 . & + & $(t)$ & 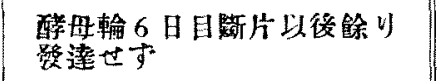 & $\#$ & - & \\
\hline $\mathrm{H} 22$ & 栅 & - & $\begin{array}{l}2 \text { 日目洞濁, 菲薄皮膜 } \\
6 \text { 日目透明, 薮 }\end{array}$ & 册 & - & 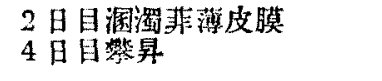 \\
\hline H 23 & $\#$ & (t) & 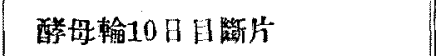 & + & $(t)$ & 同左 \\
\hline II 24 & \# & (4) & " & + & $(+)$ & "I \\
\hline IH 25 & tr & $(t)$ & $" \prime$ & + & - & \\
\hline II 26 & $(t)$ & - & & $(t)$ & - & \\
\hline II 28 & 珊 & + & 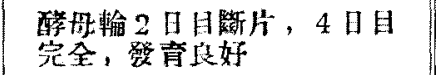 & iH & + & 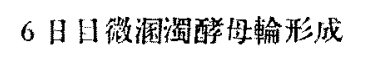 \\
\hline II 31 & $\#$ & - & & + & $(t)$ & 䣼址輸10日目断片 \\
\hline II 32 & $H$ & (t) & 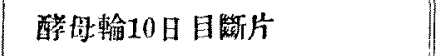 & H & + & 10日目灌醉樶輸形成 \\
\hline H 33 & + & - & & + & - & \\
\hline II 34 & + & $(t)$ & 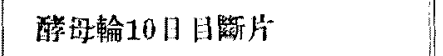 & H & + & 醇姆翰10日目形成 \\
\hline I 35 & 世 & + & 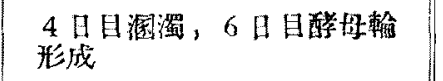 & 㖆 & + & 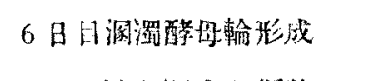 \\
\hline If 36 & 册 & + & 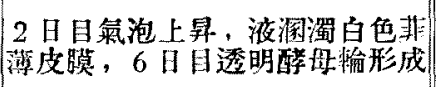 & 册 & - & 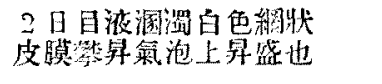 \\
\hline H 37 & + & - & & + & - & \\
\hline II 122 & 册 & - & 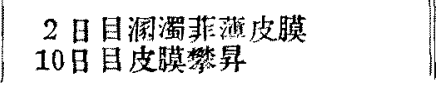 & 册 & - & 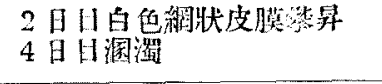 \\
\hline
\end{tabular}

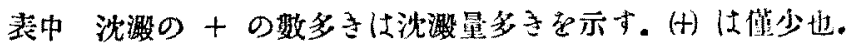

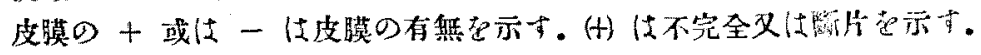

此試驗に依ると，2 日後總てが多少沈洪を生じ，而も豆汁のみの方は沈搌が底に凝集して居るに

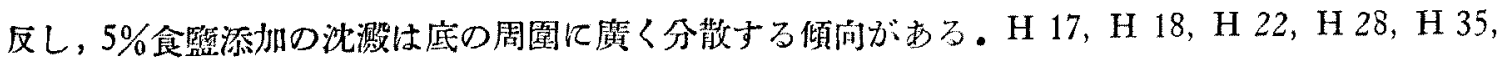


H 36，H 122 は發育良好で殊に H 36 は双方共酸酵して居る。4日は 2 日と大美なく，6日に至

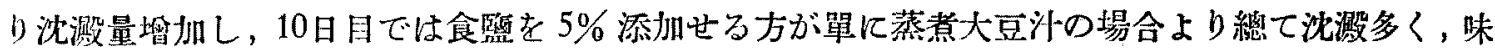
喻上り分離せる醉母には食監の必要なる事を示して居る。

（5）人工培黄基.

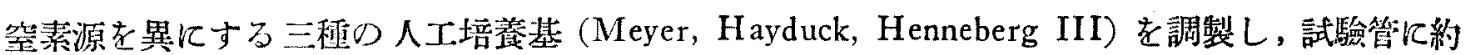

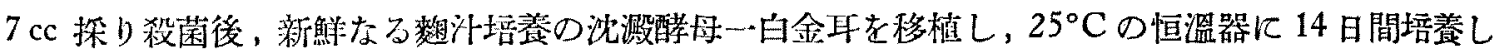
て發育の程度老鼎察した。

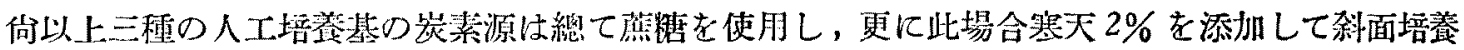
を当同時江武醶した。

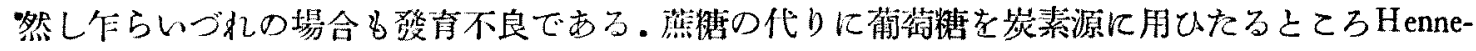
berg III が發青秒タ良好なるを示した。

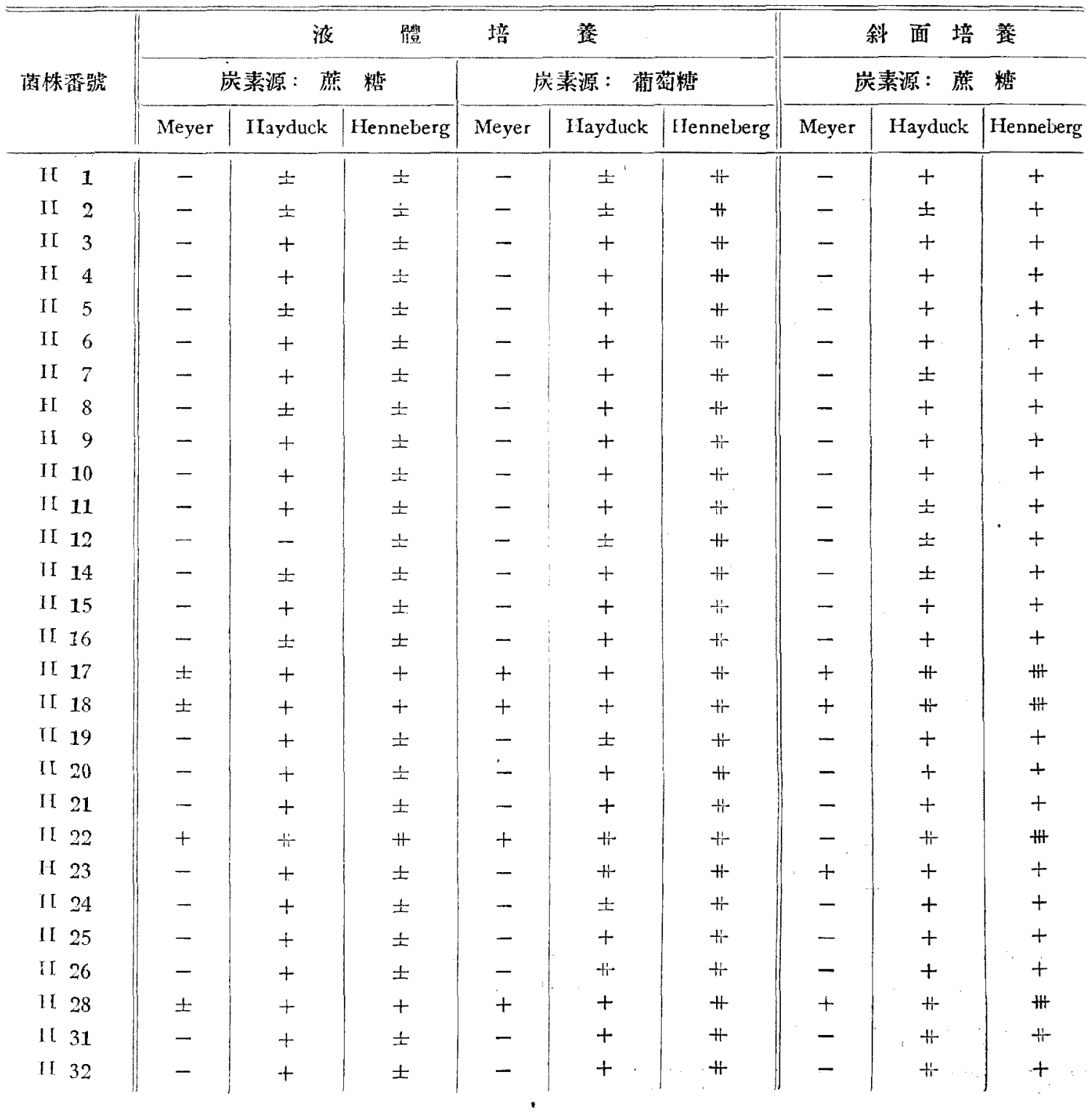




\begin{tabular}{|c|c|c|c|c|c|c|c|c|c|}
\hline H 33 & - & + & \pm & - & + & $\#$ & - & + & + \\
\hline H 34 & - & \pm & \pm & - & + & \# & - & + & + \\
\hline H 35 & - & \pm & $H$ & - & + & + & - & + & t \\
\hline II 36 & \# & Ht & \# & H & \# & H & m & H & \# \\
\hline H 37 & - & 士 & \pm & - & + & + & - & + & + \\
\hline H 122 & + & + & $\#$ & + & + & $\#$ & + & + & $H$ \\
\hline
\end{tabular}

註：士は發青僅少，十の数の多い程發育良好な万圭す。

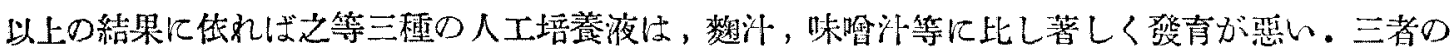

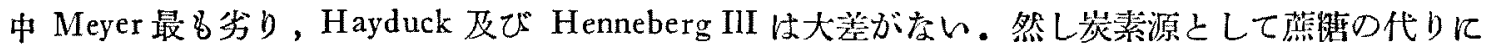

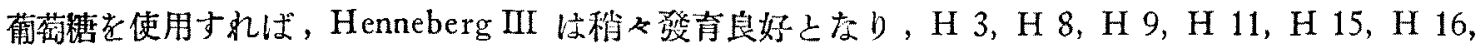

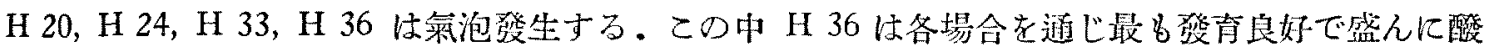
酵する.更に皮膜を形成するものは H 22，H 122 及び H 36 の三株のみで他は沈洪を生成し，或 は僅かに酵母輸の斷片を生ずる程度である。

附記：人工培養基の組成は矢の如し.

\begin{tabular}{|c|c|c|c|c|c|}
\hline & & & Meyer & Hayduck & Henneberg III \\
\hline 宸 & 素 源 & 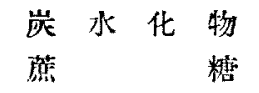 & $15.0 \%$ & $10.0 \%$ & $\overline{15.0 \%}$ \\
\hline 觉 & 素 源 & 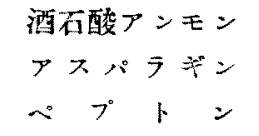 & $\frac{1.0 \%}{-}$ & {$\left[\begin{array}{c}-25 \% \\
-\end{array}\right.$} & $\bar{T}$ \\
\hline 䇿 & 機 監 & $\begin{array}{c}\mathrm{K}_{3} \mathrm{PO}_{4} \\
\mathrm{KH}_{2} \mathrm{PO}_{4} \\
\mathrm{MgSO}_{4} \cdot 7 \mathrm{H}_{2} \mathrm{O} \\
\mathrm{Ca}_{3}\left(\mathrm{PO}_{4}\right)_{2} \\
\mathrm{CaCO}_{3} \text { or } \mathrm{Na}_{2} \mathrm{CO}_{3}\end{array}$ & $\begin{array}{l}0.5 \% \\
0.25 \% \\
0.05 \% \\
\end{array}$ & $\begin{array}{l}-.1 \% \\
0.3 \% \\
- \\
\end{array}$ & $\begin{array}{l}-\overline{0.5 \%} \\
0.2 \% \\
0.5 \%\end{array}$ \\
\hline & 水 & & & & \\
\hline
\end{tabular}

3. 第 刺 培盖。

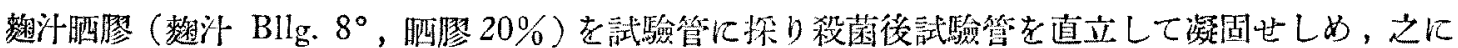

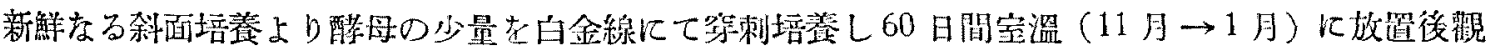
察した。

\begin{tabular}{|c|c|c|c|c|}
\hline 菌符战 & 第 & 口 & 穿 & 淽 \\
\hline $\mathrm{H} \quad 1$ & 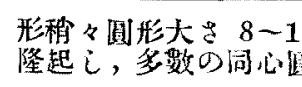 & 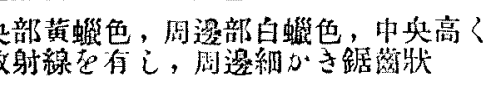 & \multicolumn{2}{|c|}{ 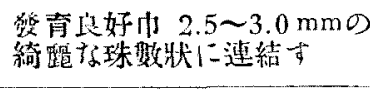 } \\
\hline $\mathrm{H}$ & 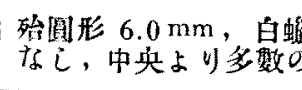 & 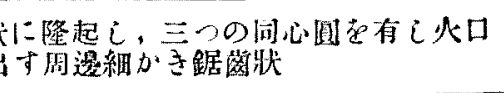 & \multicolumn{2}{|c|}{ 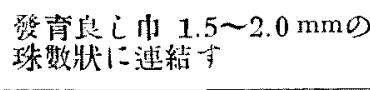 } \\
\hline $\mathrm{H} \quad 3$ & 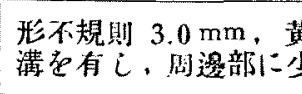 & 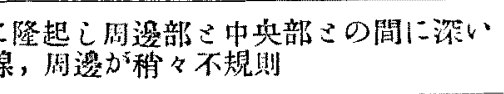 & \multicolumn{2}{|l|}{$\begin{array}{l}\text { 巾 } 1.0 \sim 2.0 \mathrm{~mm} \\
\text { 他法闹上也 }\end{array}$} \\
\hline H 4 & 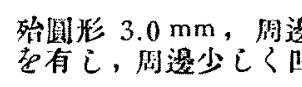 & 起 $己$ ，中央部殆 & \multicolumn{2}{|c|}{ 门 $2.0 \mathrm{~mm}$, 他は同上也 } \\
\hline
\end{tabular}




\begin{tabular}{|c|c|c|}
\hline II 5 & 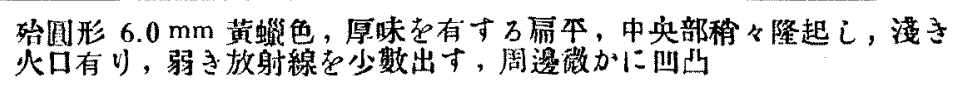 & $\begin{array}{l}\text { 巾 } 1.0-2.0 \mathrm{~mm} \\
\text { 他は同上 }\end{array}$ \\
\hline $\mathrm{H}$ & 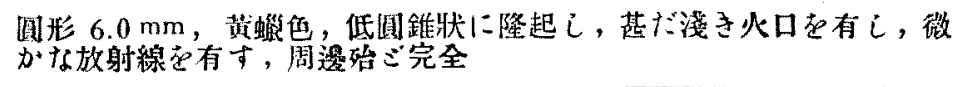 & 同 \\
\hline II 7 & 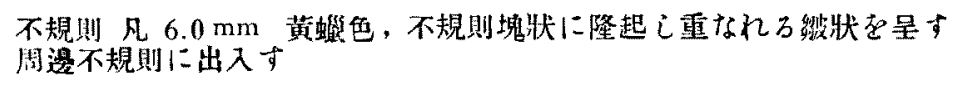 & 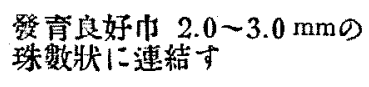 \\
\hline H 8 & 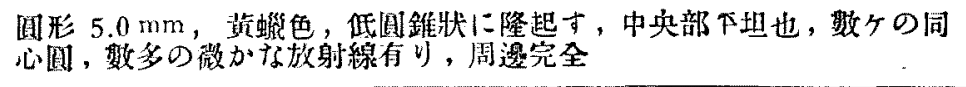 & 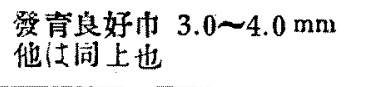 \\
\hline H 9 & 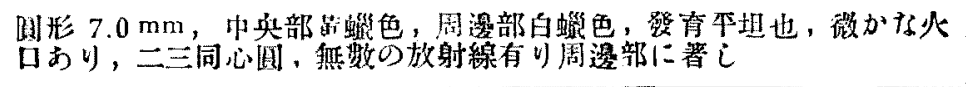 & $\begin{array}{l}\text { 巾 } 1.5 \sim 2.5 \mathrm{~mm} \\
\text { 他は同上 }\end{array}$ \\
\hline II 10 & 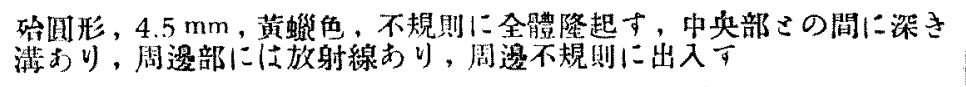 & $\begin{array}{l}2.0-2.5 \mathrm{~mm} \\
\text { 他は同上 }\end{array}$ \\
\hline II 11 & 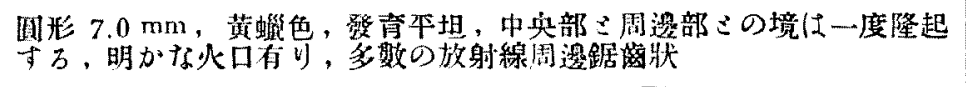 & $\begin{array}{l}10 \sim 2.0 \mathrm{~mm} \\
\text { 他は同上 }\end{array}$ \\
\hline II 12 & 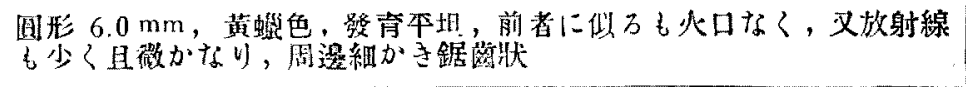 & 同 \\
\hline H 14 & 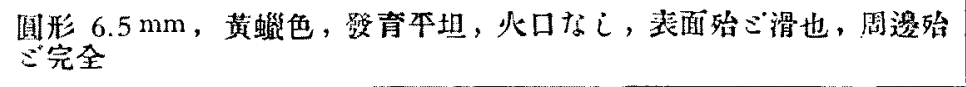 & 同 \\
\hline H 15 & 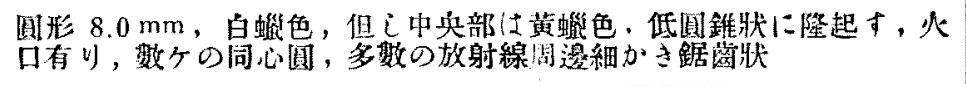 & $\begin{array}{l}2.5 \sim 4.0 \mathrm{~mm} \\
\text { 他仕同上 }\end{array}$ \\
\hline H 16 & 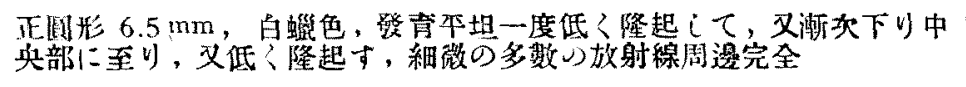 & $\begin{array}{l}1.0 \sim 1.5 \mathrm{~mm} \\
\text { 他江同上 }\end{array}$ \\
\hline H 17 & 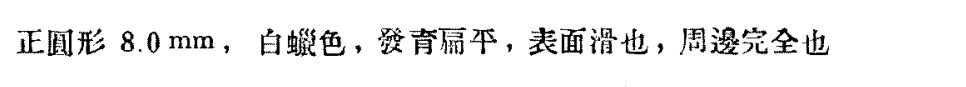 & 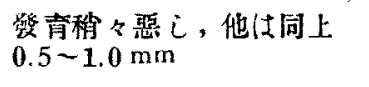 \\
\hline $\mathrm{H} 18$ & 殆ミ゙H 17 に同じ & \\
\hline II 19 & 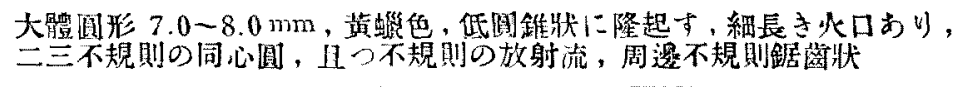 & $\begin{array}{l}\text { 巾 } 1.5 \sim 2.5 \mathrm{~mm} \\
\text { 他は闹 上 }\end{array}$ \\
\hline II 20 & 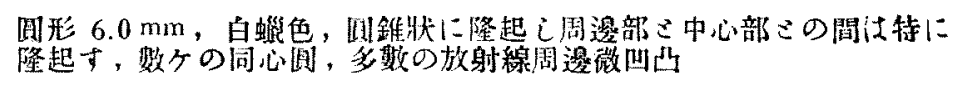 & $2.0 \mathrm{~mm}$ 他は同上 \\
\hline H 21 & 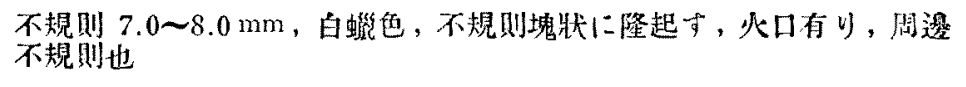 & 1.5 - 2.5 mm 他仕同上 \\
\hline II 22 & 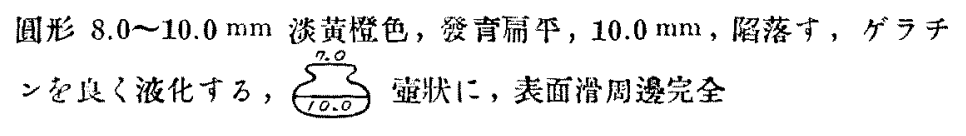 & 發青殆ミ゙無し \\
\hline II 23 & 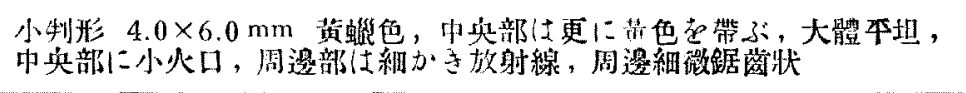 & 發育惩乞 \\
\hline H 24 & 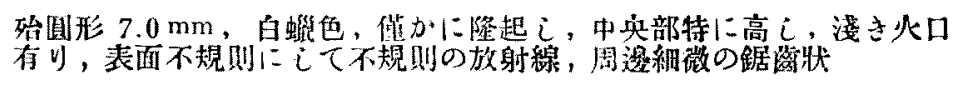 & $\begin{array}{l}\text { 發青良 } 1.5 \sim 2.0 \mathrm{~mm} \text { 珠數狀 } \\
\text { 海遇結す }\end{array}$ \\
\hline $\mathrm{H} 25$ & 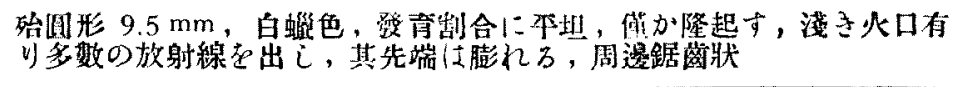 & 1.5 - 2.5 mm 他は同し \\
\hline 1126 & 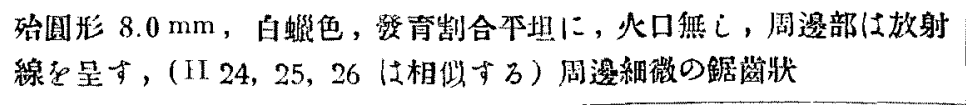 & 1.5 2.0 $\mathrm{mm}$ 他は同上 \\
\hline II 28 & 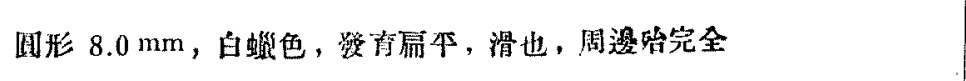 & $\begin{array}{l}\text { 發青稍々劣乃 } \\
0.5 \sim 1.5 \mathrm{~mm} \text { 他は同上 }\end{array}$ \\
\hline
\end{tabular}




\begin{tabular}{|c|c|c|}
\hline H 31 & 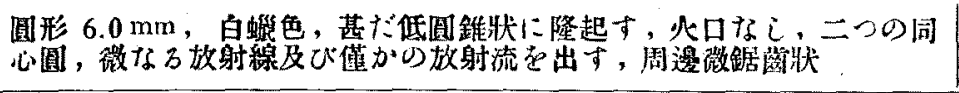 & 發青证， $2.0 \mathrm{~mm}$ ，他仗同上 \\
\hline H 32 & 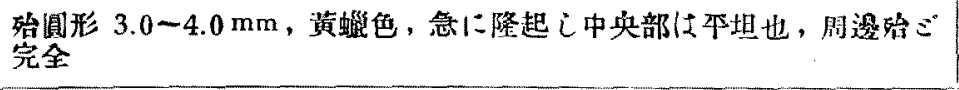 & 1.5 2.5 mm, 他は同上 \\
\hline II 33 & 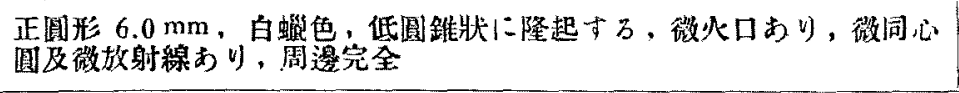 & $2.0 \mathrm{~mm}$ ，他侱同上 \\
\hline H 34 & 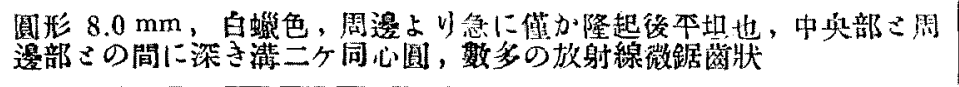 & 1.0 2.0 mm, 他は同上 \\
\hline H 35 & 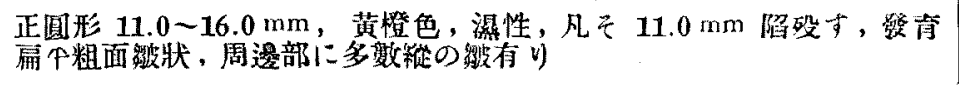 & 發奇せす \\
\hline H 36 & 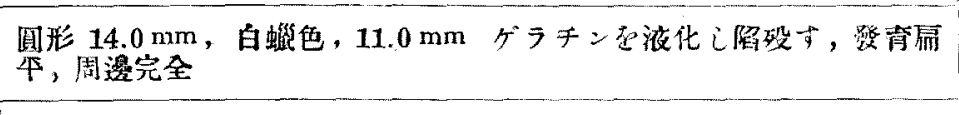 & 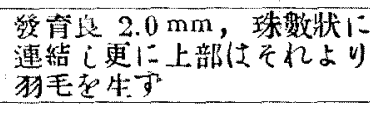 \\
\hline H 37 & 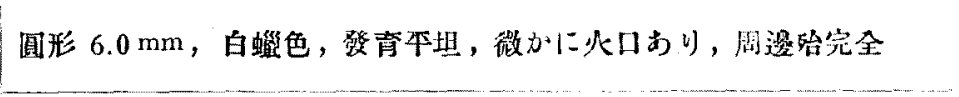 & $\begin{array}{l}\text { 發育稍々劣万 } \\
0.5-1.5 \mathrm{~mm} \text { 珠数状連結 }\end{array}$ \\
\hline II 122 & 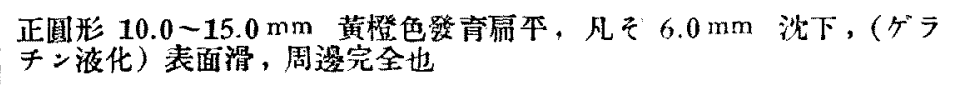 & 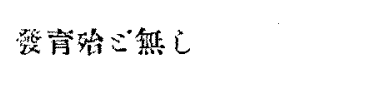 \\
\hline
\end{tabular}

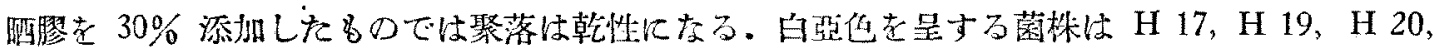
H 21, H 24, H 25, H 26, H 34，H 36 等である。30\%の場合は 20\%の場合に比し發育の程度が 劣る。特に第刺溝の發育惡〈針狀を星する菌株引多い。

4. 科面 唔 餈.

（1）数汁 寒 天。

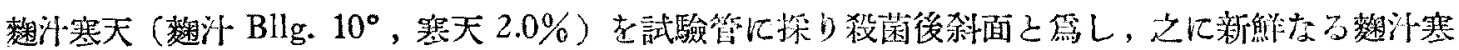

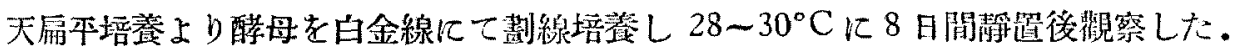

\begin{tabular}{|c|c|c|c|c|c|c|c|}
\hline 菌符號 & 色 & 起 & 督 & 放 射線 & 段 楷 & 邊 & 变面 \\
\hline H 1 & 黄䗊色 & $\begin{array}{l}\text { 中奂に向ひ綏、 } \\
\text { 隆起主 }\end{array}$ & 著しからす & 周邀部に二多數 & 微に三段 & 鋸苳㩆 & 平滑 \\
\hline $\mathrm{H} 2$ & 白的能色光澋有り & 緩く隆起す & 無 & 無 & ·奥 & 整 & $" \prime$ \\
\hline II 3 & 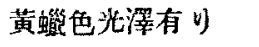 & " & 深からす & 怕しからず & $" \prime$ & 嚾加鋸落狀 & $" \prime$ \\
\hline H 4 & 暗異蟃色 & 殆ミ房华 & "I & $" \prime$ & $" \prime$ & $" \prime$ & $" \prime$ \\
\hline H 5 & 白的榇色光澤有り & 紱了隆起す & " & " & " & 整 & $" \prime$ \\
\hline If 6 & " & " & $\prime \prime$ & " & " & 嚾が鋸诺狀 & $"$ \\
\hline H 7 & 黄翼色 & 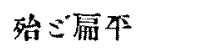 & 無 & " & 微に三段 & $"$ & $\prime \prime$ \\
\hline H 8 & 白蠉色光澤有り & 隆起马 & $"$ & 無 & 無 & 整 & $"$ \\
\hline H 9 & ." & $" 1$ & 深小的士 & "l & $"$ & $" \prime$ & " \\
\hline II 10 & 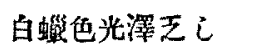 & 緩く隆起す & 無 & 細 微 & $\prime \prime$ & " & " \\
\hline II 11 & " & " & 鹿し泳からす & 閔腎部に少数 & $" \prime$ & 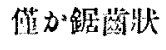 & " \\
\hline II 12 & 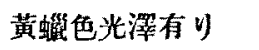 & $n$ & 著しからす & 周僈新に多鹳 & " & 鋸蔽狀 & ' \\
\hline I 14 & " & " & 深からず & 诸しからす & " & " & $" \prime$ \\
\hline If 15 & 白蟉色光涖之乙 & $"$ & 著しからすす & " & $"$ & $"$ & "I \\
\hline H 16 & 白蜼色光澤有り & " & 蔵し深からす & " & " & 整 & $" \prime$ \\
\hline II 17 & 白螦色光濢に富も & " & 㩑 & 嚾 少 & $"$ & 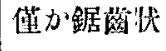 & $"$ \\
\hline H 18 & $\prime \prime$ & $" \prime$ & $" \prime$ & "I & $"$ & " & $" \prime$ \\
\hline II 19 & 黄䗨色光澤之し & $" 1$ & 梁からす & 网漫部に少数 & "I & 整 & $" 1$ \\
\hline
\end{tabular}




\begin{tabular}{|c|c|c|c|c|c|c|c|}
\hline II 20 & 畟蟉色光澤有り & 緵く隆起寸 & 著しからす & 闌嘚部に多敢 & 無 & 鋸藏狀 & 本滑 \\
\hline H 21 & 以白色光澤乏i & 㨫々高く隆起す & 中央網狀の悱 & 周僈部に多数 & $\prime \prime$ & "I & $" \prime$ \\
\hline H 22 & " & 的 本 & 無 & 無 & $\prime \prime$ & 苇が鋸藏狀 & $"$ \\
\hline II 23 & 黄白色濕性光澤えし & 紱く隆起す & 表面邹 & 䧓深部に多数 & $"$ & 鋸蓠狀 & $" \prime$ \\
\hline II. 24 & 暗兏白色光澤无i & "I & $1 "$ & " & $"$ & " & $\prime \prime$ \\
\hline H 25 & 白䗨色光濯有り & " & 表面解㩲少 & 多毁明瞭也 & $\prime \prime$ & $" \prime$ & " \\
\hline II 26 & 黄白色光滓之i & $"$ & 表面縰 & 茟だ多數 & " & " & "f \\
\hline H 28 & 白蠟色光虂に富も & $\prime \prime$ & 無 & 僅 少 & $" \prime$ & 整 & " \\
\hline H 31 & 英蜺色光澤有り & " & 著しからず & 壸しからす & $"$ & 殆こ整 & $"$ \\
\hline If 32 & $\prime \prime$ & $" \prime$ & $" \prime$ & " & $" \prime$ & $" \prime$ & " \\
\hline II 33 & $" \prime$ & $" \prime$ & 鹿し深からず & $"$ & " & $" 1$ & $"$ \\
\hline If 34 & 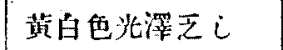 & " & 獯 & 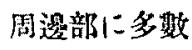 & " & 鋸茼狀 & " \\
\hline H 35 & 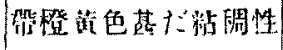 & 虑平底に降下 & " & 無 & $"$ & 整 & " \\
\hline H 36 & 白蜼色光澤有り & 原 平 & $\prime \prime$ & " & " & 僅加鋸菌狀 & $" \prime$ \\
\hline H 37 & 造蛅色光澤有 y & 始ミ゙扁乍 & $"$ & 周达部1二少影 & 微に二三段 & 整 & $" \prime$ \\
\hline H 122 & 成白色 & 病 笊 & $" \prime$ & 無 & 無 & 僅加鋸落狀 & " \\
\hline
\end{tabular}

(2) 人參汒然天。

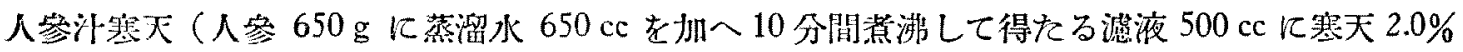

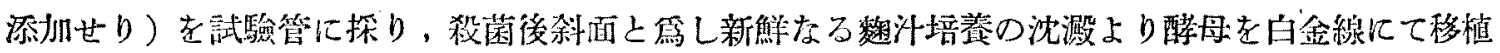

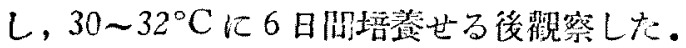

\begin{tabular}{|c|c|c|c|c|c|c|c|}
\hline 萌符 & 符號 & 色 & 隆 起 & 項 灌 & 放 射 線 & 周 & 凝 結 水 \\
\hline HI & 1 & 柇白色クリ一ム狀 & 緩 & 㽞しからす & 微 & 㮱加出入す & \\
\hline II & 2 & "I & 㱠ご甬ヤ & 㩐 & 無 & 殆ミ゙出入なi & 沈潪微星 \\
\hline H & 3 & $" \prime$ & 緩 & 著しからず & $\prime \prime$ & 嚾加出入す & \\
\hline H & 4 & $"$ & $\prime \prime$ & 無 & 猳弱渐次發澾寸 & " & 沈澱少量 \\
\hline H & 5 & $" \prime$ & 稍々急 & 著しからす。 & " & $\prime \prime$ & \\
\hline II & 6 & " & $"$ & 稍々明膫 & $\prime \prime$ & $"$ & \\
\hline II & 7 & " & 悢 & 無 & 焦 & 殆ジ出入なし & \\
\hline II & 8 & " & 盾 平 & $\prime \prime$ & 11 & 出入なi & \\
\hline II & 9 & $"$ & " & $\prime \prime$ & $\prime \prime$ & $1 "$ & \\
\hline If 1 & 10 & $"$ & 沿ご鬲本 & 落しからす & " & 僅か出入す & \\
\hline II 1 & 11 & $"$ & 緩 & $\prime \prime$ & "l & " & \\
\hline H 1 & 12 & " & 㱠ミ柰果 & 無 & 無 & $" \prime$ & \\
\hline XI 1 & & " & 原平。 & $\prime \prime$ & $" \prime$ & 殆ご出入なし & 沈测多䥣 \\
\hline II 1 & 15 & 殆ご白色クリーム䂪 & 㱠ご局ヤ & " & 徽 & 㒖か出入寸 & 沈澱中量 \\
\hline II 1 & 16 & 乳白色クリーム状 & 福 本 & " & $\prime \prime$ & " & " \\
\hline II 1 & 17 & 暗质白色クリーム状 & 治气肩本 & " & $\prime \prime$ & 出入なし & 沈漚少量 \\
\hline II 1 & & $" \prime$ & 緩 & " & $\prime \prime$ & "I & 皮膜上昇沈測多量 \\
\hline II 1 & 19 & 乳白色 & $" \prime$ & 著しかららす & $\prime \prime$ & 嚾加出入才 & \\
\hline H 2 & 20 & 乳白色クリ一ム狀 & " & $"$ & $" \prime$ & " & \\
\hline II 2 & 21 & $" \prime$ & $" \prime$ & $" \prime$ & $" \prime$ & 殆ミ゙出入なし & \\
\hline HI 2 & 22 & 白色粉狀 & 全く偏布 & 無 & 無 & $" \prime$ & 皮膜上昇沈潫有り \\
\hline II 2 & 23 & 乳白色 & 緩 & 㛶しからす & 弱 & 僅か出入す & \\
\hline if 2 & 24 & 乳白色》り一ム状 & $" 1$ & $" \prime$ & $" \prime$ & 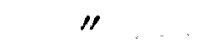 & \\
\hline
\end{tabular}




\begin{tabular}{|c|c|c|c|c|c|c|}
\hline $\begin{array}{l}\text { HI } 25 \\
\text { H } 26\end{array}$ & $\begin{array}{c}\text { 和白色 } \\
\text { " }\end{array}$ & $\begin{array}{l}\text { 縟 } \\
11\end{array}$ & $\begin{array}{c}\text { 薪しからず } \\
\text { " }\end{array}$ & 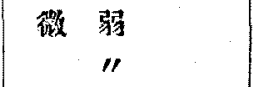 & $\begin{array}{c}\text { 嚾加出入寸 } \\
\text { " }\end{array}$ & $\begin{array}{c}\text { 皮膜上昇沈測有 } \\
\text { " }\end{array}$ \\
\hline 28 & 白色クリーム状 & 全々䨌本 & 無 & 無 & 出入なし & 皮膜上昇沈淁多㻎 \\
\hline 31 & 乳白色微稙狀 & 殆ミ゙㕄本 & $" \prime$ & 和加走放射得少需 & "I & \\
\hline 32 & 乳白色クリーム狀 & 緩 & 蓝しからす & 微 冴 & 殆:出入なi & \\
\hline 33 & "I & 原 平 & 無 & 細加走放射腺多敖 & 楅加出入寸 & 沙䬺少量 \\
\hline 34 & " & " & $\prime \prime$ & 渐次生ず & $" 1$ & \\
\hline & 暗扊色濕性》y一公狀 & $\prime \prime$ & $" \prime$ & 問 & $\prime \prime$ & \\
\hline & 白亞色 & 全く徧平 & $" \prime$ & $" \prime$ & 站ご浊入なら & 皮膜上昇 \\
\hline & 乳白色クリーム狀 & 病 本 & 蕏しがらす & 弱 & 僅加出入す & 沈檓户量 \\
\hline 122 & 白色粉狀 & 全く原平 & 然 & 哭 & 确ミ゙出入な & 级膜上豕 \\
\hline
\end{tabular}

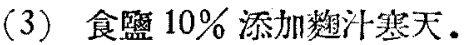

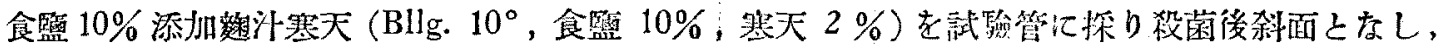

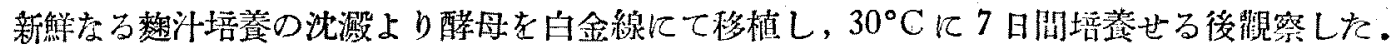

\begin{tabular}{|c|c|c|c|c|c|}
\hline 菌符號 & 色 & 表 & 僈 & 害 面 & 凝結 水 \\
\hline H 1 & 暗黄灰色 & 洞状卯級 & 不規叫鋸图牞 & 稍々攽 & \\
\hline $\mathrm{H} \quad 2$ & " & 滑 & 殆ミ゙整蜜 & 滑 & 沉洀有り \\
\hline H 3 & 暗黄裸色 & 乾性網狀緅 & 鋸苼䂧 & $\prime \prime$ & 皮膜上昇 \\
\hline II 4 & 暗黄原色 & $\prime \prime$ & 不規则に出入す & 保加紴 & $\prime \prime$ \\
\hline $\mathrm{H} 5$ & 暗黄褐色 & 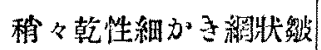 & $\prime \prime$ & $" \prime$ & $\prime \prime$ \\
\hline $\mathrm{H} 6$ & 淡黄裼色 & $" \prime$ & $" \prime$ & " & $\prime \prime$ \\
\hline $\mathrm{H} \quad 7$ & 暗黄灰色 & 乾性細加寻網狀鼣 & $\prime \prime$ & $\prime \prime$ & $\prime \prime$ \\
\hline $\mathrm{H} 8$ & 淡黄灰白色 & 娚性㞑平粗面 & 整 & 滑 & 沉澱有り \\
\hline H 9 & 暗登被色光澤有り & 乾性洏平滑䤄 & " & $\prime \prime$ & $\prime \prime$ \\
\hline II 10 & 暗黄灰色 & 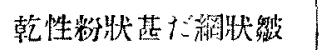 & 不規则に出入す & 级急 & 皮䑏上昇 \\
\hline II 11 & " & 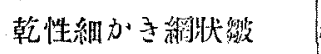 & 稍々不规泪に出入す & 嚾か嫂 & 皮膜及び沈澱 \\
\hline II 12 & $" \prime$ & $\prime \prime$ & " & $\prime \prime$ & $\prime \prime$ \\
\hline II 14 & 暗燈褟色光浲有 v & 倯々乾性鼠平滑面 & 整 & 滑 & 淡澱有り \\
\hline II. 15 & 柾白色 & 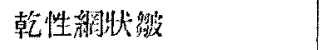 & 不規则に出入す & 僅加䖵 & \\
\hline H 16 & 暗橙褐色光澤有 り & 乾性筩平滑面 & 整 & 滑 & 沈湟有り \\
\hline H 17 & 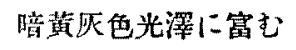 & $\prime \prime$ & $"$ & $" \prime$ & 皮膜及び沈激 \\
\hline II 18 & " & " & $\prime \prime$ & " & "l \\
\hline H 19 & 淡兴厌白色 & 乾性細狀级 & 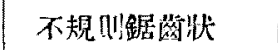 & 舅 & \\
\hline H 20 & 喑灰白色 & 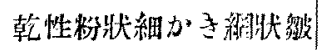 & 不規则に出入す & 桜々触 & 皮䠑上景 \\
\hline H 21 & 暗黄扊白色 & 乾性阙状鄋 & $\prime \prime$ & $" \prime$ & " \\
\hline H 22 & 乳白色 & 乾性霜平沿面 & 整 & 沿 & $" \prime$ \\
\hline H 23 & 暗黄欧白色 & 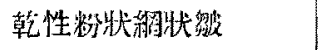 & 不規㸪に出入す & 䔎だ獭 & 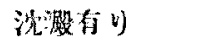 \\
\hline H 24 & 暗葷压色 & 乾性網状箙 & 不規吅鋸䕬状 & 級紧 & 皮䠑上鼠 \\
\hline H 25 & " & 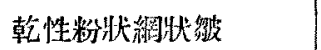 & 不規则に出入寸 & 䒫げ維 & \\
\hline $\mathrm{H} 26$ & 11 & " & " & 绯 & 农膜上舁 \\
\hline H 28 & 喑黄灰色光澤有 v & 乾性屚平滑面 & 整 & 滑 & 沈瞪有 v \\
\hline H 31 & 11 & 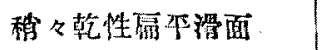 & " & $" \prime$ & $\prime \prime$ \\
\hline $\mathrm{H} 32$ & 暗黄扊色 & 乾性粉状絴狀铍 & 不規则に出入寸 & 緋 & 皮膜上昇 \\
\hline I 33 & 黄欧色光澤有 v & 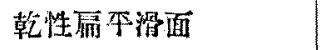 & 整 & 滑 & 沈澱有り \\
\hline
\end{tabular}




\begin{tabular}{|c|c|c|c|c|c|}
\hline $\begin{array}{l}\text { II } 34 \\
\text { II } 35\end{array}$ & 暗黄灰白色 & 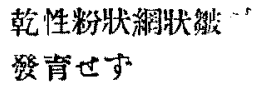 & 不規則に出入す & 㮐々敏 & 皮膜上㫧 \\
\hline II 36 & 灰白色光澤な $i$ & 乾性㾝本滑面 & 整 & 掯 & 皮膜上昇沈測有り \\
\hline 37 & 暗背灰色光汪有り & " & $"$ & " & \\
\hline If 122 & 灰白色光澤なし & " & $" \prime$ & $"$ & 皮膜上昇沈知有り \\
\hline
\end{tabular}

(4) $\mathrm{CaCO}_{3}$ 涯加数汁寒天.

数汁寒天 (Bllg. $10^{\circ}$ ，寒天 $2.0 \%$ ) 亿少量の $\mathrm{CaCO}_{3}$ 老添加し試驗管に探り殺菌後良く振盪して斜

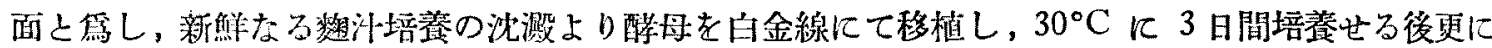
室潈（5月６月）に40日間放監後觀察した。

\begin{tabular}{|c|c|c|c|c|c|c|c|c|}
\hline 菌 茅 & 色 & 隆 起 & 頂 溸 & 故 射 線 & 斜面段譛 & 周 僈 & 塞 面 & $\begin{array}{c}\mathrm{CaCO}_{3} \\
9 \\
\text { 溶解度 }\end{array}$ \\
\hline Il 1 & 白蛡色光澤な & 扇平 & 無 & 闑僈部に=僅少 & $2 \sim 3 \mathbb{E}^{\mathrm{Z}}$ & 僅か出入す & 本滑 & + \\
\hline II 2 & 兴蜫色光澤有 V' & $" \prime$ & 蕃しからず & 無 & 無 & 整 & $\prime \prime$ & - \\
\hline H 3 & 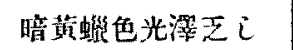 & " & 然 & 用邊部に僅少 & $\prime \prime$ & 泪かて出入す & " & + \\
\hline II 4 & 暗白既色光濢有り & $" \prime$ & 著しからず & 堹 & " & 殖ご整 & $"$ & \pm \\
\hline II 5 & 褟蝥色光澤有り & $" \prime$ & 深からす & 周遈部に僅少 & 2 段 & 偀か出入す & $" \prime$ & + \\
\hline 11 6 & 扊当蠸色光濢主己 & $\prime \prime$ & 無 & 艒 & 無 & 殆ミ゙整 & $" \prime$ & + \\
\hline II 7 & 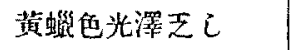 & $\prime \prime$ & 著しからす & 周道部に嚾少 & $" \prime$ & 僅か出入す & $" \prime$ & + \\
\hline H 8 & 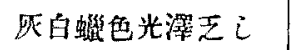 & $\prime \prime$ & " & 無 & 微 2 段 & 赔气整 & $\prime \prime$ & \pm \\
\hline II $\dot{9}$ & 黃䗨色光澤なし & $" \prime$ & 無 & & 無 & 整 & $"$ & \pm \\
\hline II 10 & 同，光澤之之 & $" \prime$ & 䈍しからする & 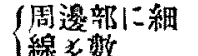 & $" 1$ & 細がく出入す & $" \prime$ & - \\
\hline II 11 & 同，光澤なi & 履平粗酌 & $\prime \prime$ & 311 & 微 2 段 & 不規則に出入す & $" \prime$ & - \\
\hline II 12 & 同，光濢有り & 扁平 & 無 & 缃邊部に嚾少 & 2 段 & $\prime$ & $" \prime$ & + \\
\hline II 14 & 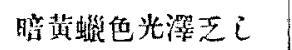 & $\prime \prime$ & $"$ & 無 & 無 & 整 & $" \prime$ & \pm \\
\hline II 15 & 白蠟色光澤なし & " & 深からす & $\prime \prime$ & $" \prime$ & 細かく出入す & $"$ & - \\
\hline If 16 & 暗益蜫色光濢存り & $" \prime$ & 昰しからす & " & $" \prime$ & 整 & $" \prime$ & - \\
\hline 1117 & 白亞色炕澤永し & 䙵平缴 & 無 & $" \prime$ & 微 2 段 & 不規则に出入す & $\prime \prime$ & + \\
\hline 1118 & " & 原平鰐肌 & " & $" \prime$ & 無 & 嚾加出入す & 稍々解 & + \\
\hline II 19 & 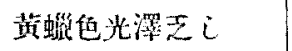 & 俩平 & 暜しからず & 閏邊部に蛜少 & 微 2 段 & 細かく出入す & 平滑 & \pm \\
\hline II 20 & " & $\prime \prime$ & " & 無 & $"$ & 知ご整 & $" \prime$ & \pm \\
\hline H 21 & 同，光濢な气 & 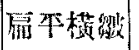 & 無 & 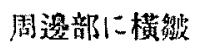 & 無 & 不規則に出入寸 & 秛多数 & - \\
\hline II 22 & 乳白色光檌无に & 俩平 & $\prime \prime$ & 無 & 微 2 段 & 殆ご整 & 本滑 & - \\
\hline II 23 & 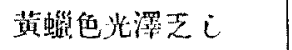 & $\prime \prime$ & $" \prime$ & $\prime \prime$ & $\prime \prime$ & " & $\prime \prime$ & - \\
\hline II 24 & 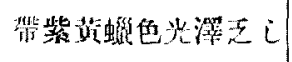 & 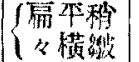 & $"$ & $"$ & $\prime \prime$ & 不規則に出入才 & 倯々橫吻 & \pm \\
\hline II 25 & $" \prime$ & 螎年 & $"$ & 問遈部に僅少 & $\prime \prime$ & 細かく出入す & 平滑 & \pm \\
\hline JI 26 & 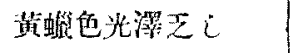 & $\prime \prime$ & $"$ & 热 & 無 & 不規则に出入す & $\prime \prime$ & - \\
\hline II 28 & 白亞色洸虂な & 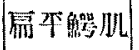 & " & $\prime \prime$ & $" \prime$ & 不規則鋸莮狀 & 淞々緒 & + \\
\hline If 31 & 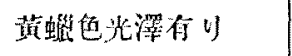 & 殆に厚平 & 深むらず & $" \prime$ & 2 段 & 整 & 平滑 & \pm \\
\hline II 32 & 褐䗊色洸澤有り & 痛平 & 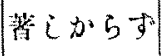 & $"$ & 無 & 不規則に出入す & $\prime \prime$ & - \\
\hline H 33 & 奖蜼色光攞玉i & " & " & $"$ & 微 2 段 & 殆ミ整 & $" \prime$ & $士$ \\
\hline If 34 & " & ${ }^{\prime \prime}$ & $\prime \prime$ & $"$ & 然 & 僅か出入す & $" \prime$ & - \\
\hline II 35 & 暗䶂色 & $\left\{\begin{array}{l}\text { 鬲华 } \\
\text { 粘养性 }\end{array}\right.$ & 無 & " & $\prime \prime$ & 不規則に出入す & $"$ & - \\
\hline II 36 & 灰白色粉状 & 府舟 & $"$ & $" \prime$ & $\prime \prime$ & $" 1$ & $"$ & \# \\
\hline II 37 & 白蛅色沈濯有り & $" \prime$ & $"$ & $" \prime$ & " & 整 & $"$ & \pm \\
\hline II 122 & 乳白色光濹无之 & $\prime \prime$ & $\prime \prime$ & $" \prime$ & 微數段 & 不规則に出入すす| & $"$ & + \\
\hline
\end{tabular}


（5）人參及び馬鈴薯培䓹.

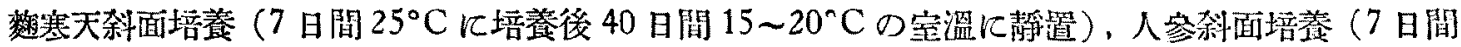
$25^{\circ} \mathrm{C}$ 亿培盖後 $15 \sim 20^{\circ} \mathrm{C}$ の室溫に28日間静置)，馬鈴著斜面培養の條件は人參の場合と同じである。

\begin{tabular}{|c|c|c|c|c|c|c|c|c|c|c|}
\hline & 色 & 隆 起 & 頂 淽 & 同心圆 & 放射線 & 段 楷 & 問 邀 & 表 面 & 裹 & 面 \\
\hline \multirow{3}{*}{$\mathrm{H} \stackrel{*}{1}$} & 淡黄扊蠟色 & & & $\begin{array}{l}\text { 下部1: } \\
\text { 部 }\end{array}$ & 弱子七多数 & 上部に二二段 & 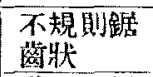 & 粗 面 & 滑 & \\
\hline & 秏白色 & 高 く隆起寸 & & & & & 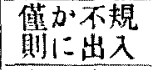 & " & & \\
\hline & $\begin{array}{l}\text { 焱皇 } \\
\text { 稳 } 8 \text { 光瀑 }\end{array}$ & 隆起 寸 & 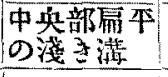 & & & & 出入少な & 稍々祗面 & & \\
\hline \multirow{3}{*}{ H 2} & 淡畟灰蛝色 & & & 無 $i$ & 無 $i$ & 不完全 1 ケ & 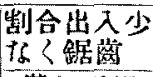 & 制合滑 & 滑 & \\
\hline & 乳白色 & 隆起す & & & & 1 段 & $\begin{array}{l}\text { 僅が不規 } \\
\text { 則に二出入 }\end{array}$ & 粗 & & \\
\hline & 灰白色 & " & 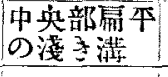 & & & & $\begin{array}{l}\text { 細かく出 } \\
\text { 入す }\end{array}$ & $" \prime$ & & \\
\hline \multirow{3}{*}{$\mathrm{H} 3$} & 畟褐 色 & & & 無 $i$ & 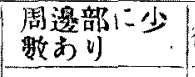 & 微かけ二2段 & 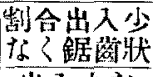 & 稆 $、$ 粗 & 滑 & \\
\hline & 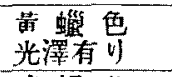 & 隆起す & & & & & $\begin{array}{l}\text { 出入少掠 } \\
\end{array}$ & 滑 & & \\
\hline & 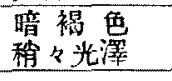 & $\begin{array}{l}\text { 不規則兵 } \\
\text { 鼎に隆起 }\end{array}$ & & & & & 出入去り & 稍々滑 & & \\
\hline \multirow{3}{*}{ H 4} & 灰螅色 & & & 無 $i$ & & 無 $i$ & $\begin{array}{l}\text { 裂ご出入 } \\
\text { 小く芫全 }\end{array}$ & 滑面 & 消 & \multirow{3}{*}{$\begin{array}{l}\text { 發青 } \\
\text { 尐 }\end{array}$} \\
\hline & $\begin{array}{l}\text { 乳皇魚 } \\
\text { 光澤有响 }\end{array}$ & 隆起す & & & & & $\begin{array}{l}\text { 出入少小 } \\
\text { i }\end{array}$ & $"$ & & \\
\hline & 孚白色 & 隆起す & $\begin{array}{l}\text { 中奥部畨 } \\
\text { 合扁平地 }\end{array}$ & & & & " & 粗面 & & \\
\hline \multirow{3}{*}{ H 5} & 灰蠟色 & & & 無 $i$ & 無 $\quad \mathcal{~}$ & 微かに 2 段 & $\begin{array}{l}\text { 烈に゙出入 } \\
\text { 完全 }\end{array}$ & 祎 & \multicolumn{2}{|l|}{ 滑 } \\
\hline & $\begin{array}{l}\text { 孚帛色 } \\
\text { 光㵏有叫 }\end{array}$ & 高く隆起 & & & & & ${ }_{i}^{\text {出入少小 }}$ & " & & \\
\hline & 欧白色 & 隆起す & $\begin{array}{l}\text { 中暗部制 } \\
\text { 然也 }\end{array}$ & & & & $"$ & 粗面 & & \\
\hline \multirow{3}{*}{ H 6} & 灰 䗘 色 & & & 無 $i$ & $\begin{array}{l}\text { 鈍く短く少 } \\
\text { 敢 }\end{array}$ & 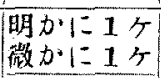 & 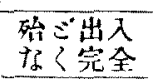 & 浑 & \multicolumn{2}{|l|}{ 滑 } \\
\hline & 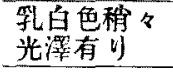 & $\begin{array}{l}\text { 高かく隆 } \\
\text { 起 }\end{array}$ & & & & & 出入少は & 稍々滑 & & \\
\hline & 暗圧白色 & 刷 平 & & & & & $\begin{array}{l}\text { 不規则に } \\
\text { 出入主方 }\end{array}$ & $\prime \prime$ & & \\
\hline \multirow{3}{*}{ H 7} & 暗黄酸色 & & & & & & 鋸 薢 狀 & |全面緝狀 & & \\
\hline & 異螆色 & 隆起す & & & & & 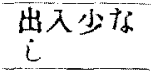 & 微粒㹜 & & \\
\hline & 暗灰色 & " & 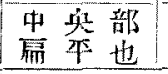 & & & & " & 粗面 & & \\
\hline \multirow{3}{*}{ If 8} & 暗黄酸色 & & & & & & 惻合完全 & 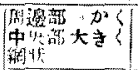 & \multicolumn{2}{|l|}{ i } \\
\hline & 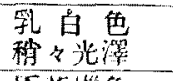 & 隆起寸 & & & & & 出入少小 & 稍々㵢 & & \\
\hline & 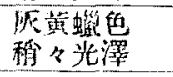 & 殆㟨平 & & & & & " & " & & \\
\hline \multirow{6}{*}{$\mathrm{H} \quad 9$} & 帶紫琾蠟色 & & & 無i & $\begin{array}{l}\text { 上下共に細か } \\
\text { 夺多酸放射楾 }\end{array}$ & 微かに1ケ & 完 全 & 管 & 滑 & \\
\hline & $\begin{array}{l}\text { 乳泉色 } \\
\text { 光澤有り }\end{array}$ & 高く隆起 & & & & & 出入す & " & & \\
\hline & 灰白色 & 隆起す & 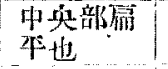 & & 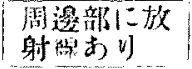 & & ${ }_{i}^{\text {出入少 } 16}$ & 稍的淉 & \multirow{4}{*}{\multicolumn{2}{|c|}{ 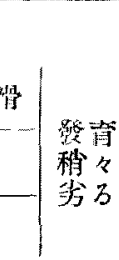 }} \\
\hline & 灰蕧蠟色 & 隆起僅 & & 無 $己$ & 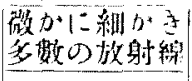 & 1 ケ & 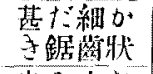 & 稍々粗 & & \\
\hline & 孚白色 & 膏人隆起 & & & & & 出入少な & 粗面 & & \\
\hline & 戻白色 & 急に隆起 & $\begin{array}{l}\text { 中尖部扁 } \\
\text { 平 }\end{array}$ & & 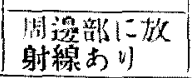 & & 出入すり & 稍々滑 & & \\
\hline
\end{tabular}




\begin{tabular}{|c|c|c|c|c|c|c|c|c|c|c|}
\hline \multirow{3}{*}{ H 11} & 灰白螨色 & & & 無 $己$ & 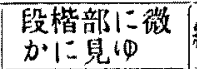 & 綺䁃に 3 ケ & 殆完全 & 稍々租 & 滑 & \\
\hline & $\begin{array}{l}\text { 乳白色 } \\
\text { 光湳有 }\end{array}$ & 隆赸す & & & & & 出入少な & 滑面 & & \\
\hline & $\begin{array}{l}\text { 灰黄蚿色 } \\
\text { 光摆おり }\end{array}$ & 殆 薪 平 & & & & & 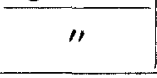 & 滑面濕性 & & \\
\hline \multirow{3}{*}{ H 12} & 灰白螠色 & & & 無 $i$ & $\begin{array}{l}\text { 段楷部に } 3 \\
\text { 段上部は微 }\end{array}$ & 3 段 & 殆完全 & 滑 & 滑 & \multirow{3}{*}{$\begin{array}{l}\text { 發育 } \\
\text { 劣万 }\end{array}$} \\
\hline & $\begin{array}{l}\text { 乳㒶色 } \\
\text { 光罢有り }\end{array}$ & $\begin{array}{l}\text { 高く隆起 } \\
\text { 寸 }\end{array}$ & & & & & $\begin{array}{l}\text { 出入少な } \\
\text { ¿ }\end{array}$ & $\prime \prime$ & & \\
\hline & 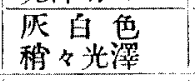 & 隆起す & 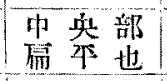 & & & & "I & 稍々滑 & & \\
\hline \multirow{3}{*}{ II 14} & 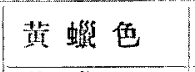 & & & 無 $i$ & $\begin{array}{l}\text { 細加放射 } \\
\text { 線 }\end{array}$ & $\begin{array}{l}\text { 上部微か。 } \\
\text { に1段 }\end{array}$ & 完 全 & 稍々滑 & \multicolumn{2}{|l|}{ 滑 } \\
\hline & $\begin{array}{l}\text { 黄蟔色 } \\
\text { 光浔有り }\end{array}$ & 隆起す & & & & & 出入少な & 滑 & & \\
\hline & 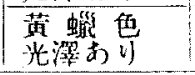 & " & 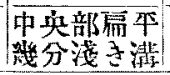 & & & & " & $\prime \prime$ & & \\
\hline \multirow{3}{*}{ H 15} & 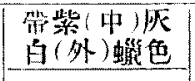 & & & $\begin{array}{l}\text { 下部に } \\
75\end{array}$ & 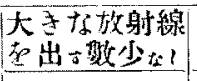 & $\frac{\text { 上部に }}{\text { 段 }}$ & $\begin{array}{l}\text { 細か・き鋸 } \\
\text { 欲㕱 }\end{array}$ & 稍々滑 & \multicolumn{2}{|l|}{ 喑 } \\
\hline & 乳 白色 & 隆起す & & & & & 出入有v & 粗 & & \\
\hline & 灰白色 & $" \prime$ & $\begin{array}{l}\text { 中央部甬 } \\
\text { 平 }\end{array}$ & & & & $\begin{array}{l}\text { 不规則大 } \\
\text { 出出入 }\end{array}$ & $\prime \prime$ & & \\
\hline \multirow{3}{*}{ H 16} & 喑莼蛅色 & 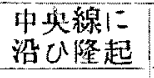 & & 無 $己$ & 無 $i$ & 無 $\quad$ & 殆完全 & 滑 & \multicolumn{2}{|l|}{ 滑 } \\
\hline & $\begin{array}{l}\text { 孚昌色 } \\
\text { 光潀有 到 }\end{array}$ & 隆起す & & & & & 出入有り & " & & \\
\hline & $\begin{array}{l}\text { 暗灰色 } \\
\text { 光澤む叮 }\end{array}$ & $\prime \prime$ & $\begin{array}{l}\text { 中奂部原 } \\
\text { 平也 }\end{array}$ & & & & $\begin{array}{l}\text { 不規則に大 } \\
\text { 出? }\end{array}$ & 谓面濕性 & & \\
\hline \multirow{3}{*}{ H 17} & $\begin{array}{l}\text { 暗クリーム } \\
\text { 色 }\end{array}$ & & & 無 & 無 $i$ & 無 $i$ & $\begin{array}{l}\text { 殖完全一 } \\
\text { 部維毛状 }\end{array}$ & 滑 & \multicolumn{2}{|l|}{ 消 } \\
\hline & 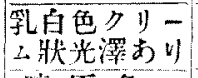 & 隆起す & & & & & $\begin{array}{l}\text { 出入少な } \\
\text { C }\end{array}$ & $\prime \prime$ & & \\
\hline & $\begin{array}{l}\text { 喑 灰色 } \\
\text { 秒々光澤 }\end{array}$ & 砝 原 平 & & & & & $\prime \prime$ & $\begin{array}{l}\text { 中央粗 } \\
\text { 滔滑 }\end{array}$ & & \\
\hline \multirow{3}{*}{ H 18} & $\div \mathrm{HI} 17$ & & & & & & & & & \multirow{3}{*}{$-\begin{array}{l}\mathrm{H}_{171} \\
\text { 比 } i \\
\text { 穆 } \\
\text { 劣 }\end{array}$} \\
\hline & $\because \mathrm{H}_{17}$ & & & & & & & & & \\
\hline & 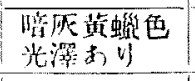 & 殆冨本 & & & & & 岃入少は & $\begin{array}{l}\text { 表面滑 } \\
\text { 濕性 }\end{array}$ & & \\
\hline \multirow{3}{*}{ H 19} & 灰白色 & & & 無i & 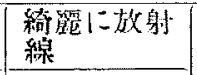 & $\begin{array}{l}\text { 上部微加 } \\
1=2 \varepsilon^{*}\end{array}$ & $\begin{array}{l}\text { 僅かた出 } \\
\text { 入す }\end{array}$ & 粗面 & 镪 & \multirow{3}{*}{$\begin{array}{l}\text { 㮐 } \\
\text { 劣 }\end{array}$} \\
\hline & 跳白色 & 高く隆起 & & & & & $\begin{array}{l}\text { 出入少な } \\
\text { C }\end{array}$ & $\prime \prime$ & & \\
\hline & 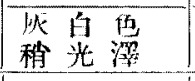 & 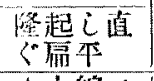 & & & & & 11 & 稍々膤 & & \\
\hline \multirow{3}{*}{ H 20} & 灰白䗜色 & $\begin{array}{l}\text { 中真線に } \\
\text { 沿U際起 }\end{array}$ & & 無 $i$ & 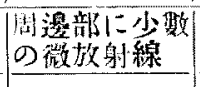 & 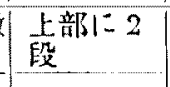 & 㶵かに出 & 粗面 & $i^{7}$ & \multirow{3}{*}{$\begin{array}{l}\text { 發春 } \\
\text { 劣b }\end{array}$} \\
\hline & 乳昌色 & 隆起才 & & & & & $\underbrace{\text { 出入少な }}$ & $\prime \prime$ & & \\
\hline & $\begin{array}{l}\text { 喑潶扊色 } \\
\text { 稍々光澤 }\end{array}$ & 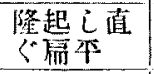 & & & & & $\prime \prime$ & 稍々沿 & & \\
\hline \multirow{3}{*}{ H 21} & 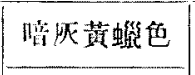 & & & 無乞 & 無 & 無 $i$ & $\begin{array}{l}\text { 不規帅: } \\
\text { 出入 }\end{array}$ & 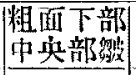 & \multicolumn{2}{|l|}{ 谓 } \\
\hline & 乳白色 & 隆 起 导 & & & & & 出入少小 & 粗面 & & \\
\hline & 灰白色 & $\begin{array}{l}\text { 隆起乞 } \\
\text { 南ぐ质本 }\end{array}$ & $\begin{array}{l}\text { 中奥の一 } \\
\text { 綵に滥 }\end{array}$ & & 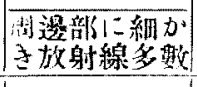 & t & " & $\prime \prime$ & & \\
\hline \multirow{3}{*}{ II 22} & 淡萿色 & & " & 然 $i$ & 無 $i$ & 啇 $i$ & 完 全 & 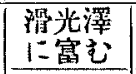 & \multicolumn{2}{|l|}{ 滑 } \\
\hline & $\begin{array}{l}\text { 灰香 色 } \\
\text { 光澤む叫 }\end{array}$ & 隆 起 寸 & & & & & $\begin{array}{l}\text { 出入少な } \\
\text { 至 }\end{array}$ & 滑面 & \\
\hline & 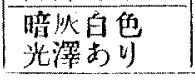 & 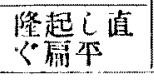 & & & & & $\prime \prime$ & $" \prime$ & & \\
\hline
\end{tabular}




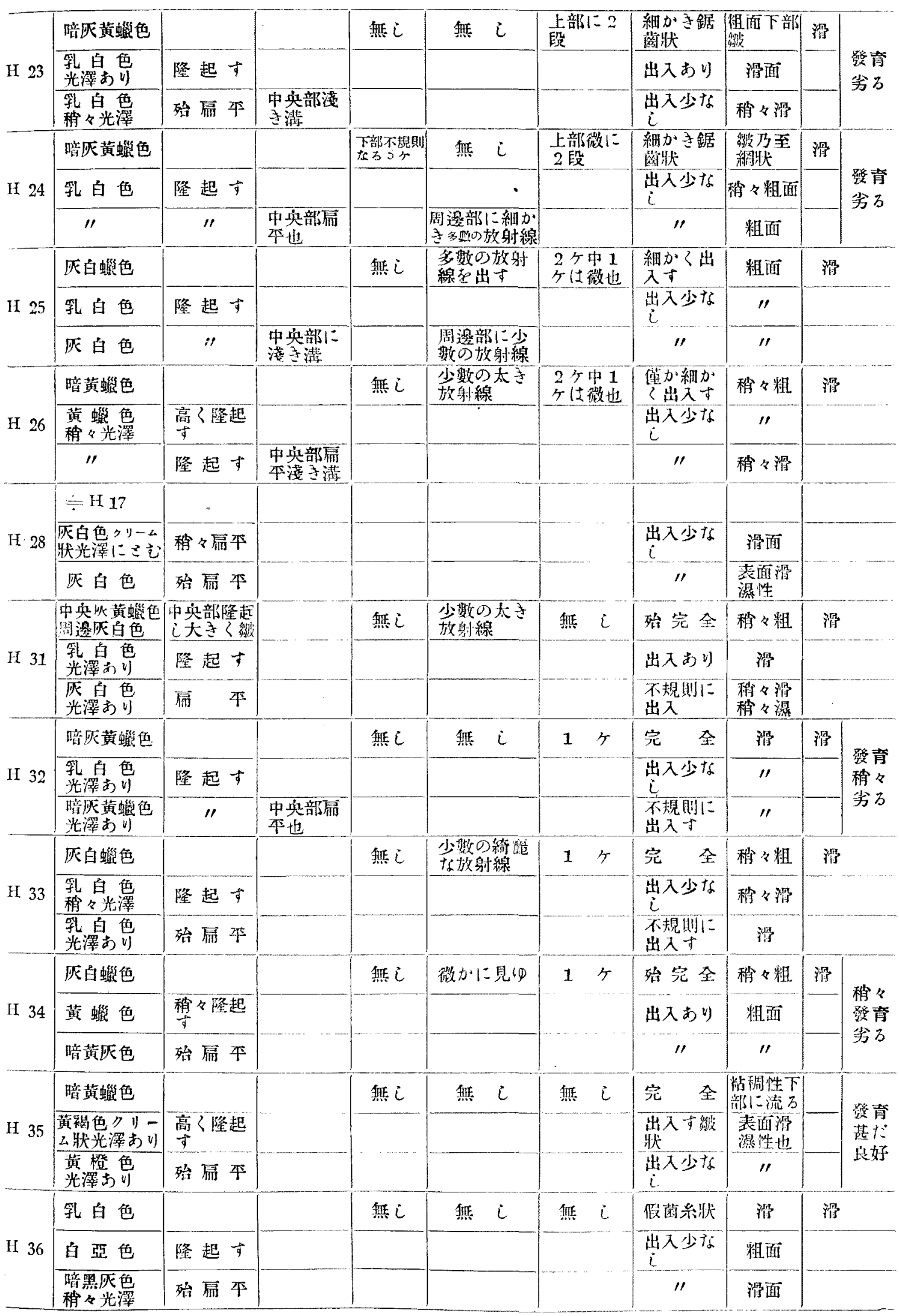




\begin{tabular}{|c|c|c|c|c|c|c|c|c|c|c|}
\hline \multirow{3}{*}{ H 37} & 暗畟蛇色 & & & 無 $i$ & 微かに有り & 1 & $ケ$ & 完 全 & 殆猾 & 滑 \\
\hline & $\begin{array}{l}\text { 乳香色 } \\
\text { 光澤む叫 }\end{array}$ & 隆起す & & & & & & 出入少な & 滑面 & \\
\hline & $\begin{array}{l}\text { 暗畦火色 } \\
\text { 稍々光淬 }\end{array}$ & "I & $\begin{array}{l}\text { 中央部洏 } \\
\text { 年世 }\end{array}$ & & & & & "' & 㮐々滑 & \\
\hline \multirow{3}{*}{ H 122} & 淡喑鱼色 & & & 無 $己$ & 無 $i$ & 無 & $i$ & 完 全 & 滑 & 滑 \\
\hline & 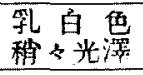 & 隆起す & & & & & & 出入少な & 稳々粗 & \\
\hline & 账白色 & "' & $\begin{array}{l}\text { 中央部屌 } \\
\text { 尔也 }\end{array}$ & & & & & "I & 粗面 & \\
\hline
\end{tabular}

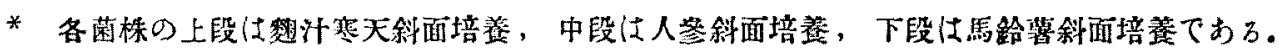

5. 聚落の形態。

(1) 小聚落 (届平培䓹).

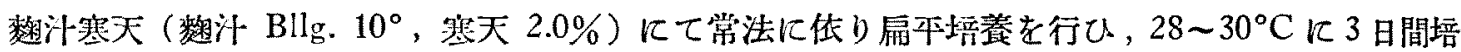
養せる後觀察した。

\begin{tabular}{|c|c|c|c|c|c|c|}
\hline \multirow{2}{*}{\multicolumn{2}{|c|}{ 菌株符號 }} & \multirow{2}{*}{ 色 } & \multirow{2}{*}{ 形狀 } & \multicolumn{2}{|c|}{ 閣 } & \multirow{2}{*}{$\begin{array}{l}\text { 内部に發育さ } \\
\text { 万篍落及其他 }\end{array}$} \\
\hline & & & & 肉 眼 & 捇大（130倍） & \\
\hline $\mathrm{H}$ & 1 & 乳白色光澤有り & 圂]形弧狀高 く隆起 & 整 & 整, 均質暗黄嘿色 & 假菌糸狀 \\
\hline $\mathrm{H}$ & 2 & " & $"$ & " & 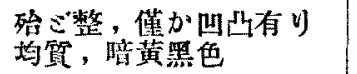 & " \\
\hline & 3 & $\prime \prime$ & $\prime \prime$ & $\prime \prime$ & " & " \\
\hline II & 4 & $\prime \prime$ & $\prime \prime$ & " & 整，均貿，暗黄色 & \\
\hline II & 5 & $\prime \prime$ & " & $\prime \prime$ & 整，暗黄灰色 & 問澳鉏狀也 \\
\hline $\mathrm{H}$ & 6 & $\prime \prime$ & $\prime \prime$ & $" \prime$ & 整, 暗黄黑色 & " \\
\hline $\mathrm{H}$ & 7 & 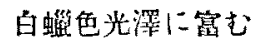 & $\prime \prime$ & $" \prime$ & 整, 均質, 喑黄黑色 & \\
\hline $\mathrm{H}$ & 8 & 白蜭色光澤有り & 圓形弧狀低 乙隆起 & $" \prime$ & " & \\
\hline FI & 9 & 乳白色光濢有り & 圆形弧狀に隆起す & $\prime \prime$ & " & \\
\hline & 10 & $"$ & 圆]形泒狀高：隆起 & $\prime \prime$ & $" \prime$ & \\
\hline & 11 & " & 圆形强狀に隆起す & $\prime \prime$ & 整，均筫世 & 周還稙狀也 \\
\hline & 12 & 黄 蟠 色 & $\prime \prime$ & " & " & " \\
\hline $\mathbf{H I}$ & 14 & 乳白色光澤有り & $" \prime$ & " & 整，均質喑黄哭色 & \\
\hline $\mathrm{H}$ & 15 & $" \prime$ & 圆形弧将高？隆起 & $" \prime$ & " & 周㩧露出市 \\
\hline $\mathrm{H}$ & 16 & $"$ & 回形弧状に隆起す & $\prime \prime$ & $\prime \prime$ & 祘邊粒缸也 \\
\hline $\mathrm{H}$ & 17 & 乳白色光溒に篦む & $\prime \prime$ & " & $\prime \prime$ & " \\
\hline II & 18 & 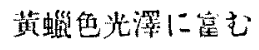 & $\prime \prime$ & $\prime \prime$ & " & $" \prime$ \\
\hline II & 19 & 白蛣光㵋有り & $\prime \prime$ & " & $" \prime$ & $" \prime$ \\
\hline II & 20 & 孚白色光㭴有り & " & $\prime \prime$ & " & \\
\hline II & 21 & 乳 白 色 & $\prime \prime$ & $" \prime$ & $" \prime$ & 問遗㮐々精狀 \\
\hline HI & 2,2 & 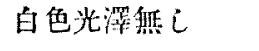 & 国形愿平也 & 鋸蒛状 & 凹凹右り，完全暗扊黑色 & 表面良發青 \\
\hline $\mathrm{H}$ & 23 & 乳白色光踣存り & 圆形弧状に隆杞す & 整 & 整，均留，喑黄垚色 & 周逶稙狀露出 \\
\hline $\mathrm{H}$ & 24 & " & " & $\prime \prime$ & $"$ & \\
\hline II & 25 & $"$ & $" \prime$ & $" \prime$ & $" \prime$ & \\
\hline $\mathrm{H}$ & 26 & " & $\prime \prime$ & $"$ & $"$ & \\
\hline $\mathrm{H}$ & 28 & 药螆色光濯有り & " & $"$ & " & \\
\hline II & 31 & 乳白色光罯有り & "' & $" \prime$ & $" \prime$ & 周缐粒狀露出 \\
\hline II & 32 & " & $" \prime$ & $\prime \prime$ & $\prime \prime$ & 周邊敉狀 \\
\hline
\end{tabular}




\begin{tabular}{|c|c|c|c|c|c|}
\hline H 33 & 孚白色光濢有 v & 固形㭛狀に隆起す & 整 & 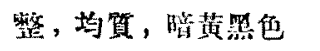 & \\
\hline H 34 & 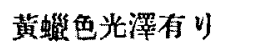 & " & $\prime \prime$ & " & \\
\hline HI 35 & 黄裸色光涬薪乞 & 国形大也弧狀隆起 & " & 整，均質 & 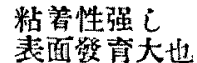 \\
\hline H 36 & 白色兆澤有 v & 国形中央㮐々隆起 & " & 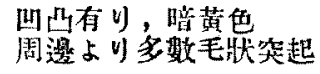 & \\
\hline H 37 & 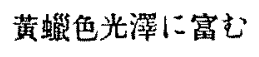 & 圆形弧狀に二隆起寸 & " & 殆整，暗異黑色 & \\
\hline H 122 & 白色光澤無 & 路形酉平世 & 鋸落狀 & 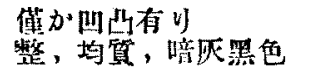 & \\
\hline
\end{tabular}

（2）巨大聚落（其一）。

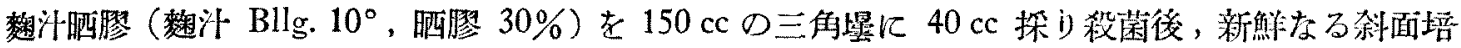
養より酵母白金線にて少量採り，唒翏上に僅加接觸する程度に移植し室温 $\left(5 \sim 25^{\circ} \mathrm{C}\right)$ に 160 日 間靜置後觀察した。

\begin{tabular}{|c|c|c|c|c|c|c|c|}
\hline 菌符號 & 色 & 傾 斜 & 火口の狀態 & 同 心 圆 & 放 射 楾 & 墨 酶 & 其 \\
\hline $\mathrm{H} \quad 1$ & $\begin{array}{l}\text { 周逪部白 } \\
\text { 色, 中奂 } \\
\text { 部萲白色 }\end{array}$ & $\begin{array}{l}\text { 中奂部隆 } \\
\text { 起 }\end{array}$ & 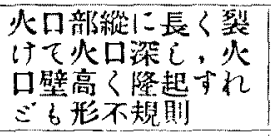 & 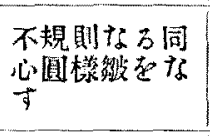 & 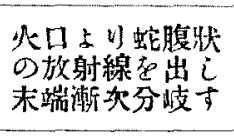 & 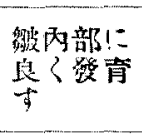 & 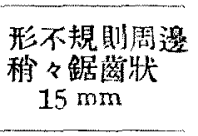 \\
\hline H 2 & 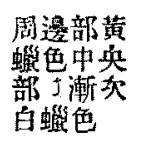 & 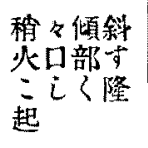 & $\begin{array}{l}\text { 僅かに淺き小清を } \\
\text { 存し，中奂部粉狀 }\end{array}$ & $\begin{array}{l}\text { 數重の色柇的 } \\
\text { 同心国を呈す }\end{array}$ & $\begin{array}{l}\text { 數條の淺寻漌櫒 } \\
\text { の放射線 }\end{array}$ & $\begin{array}{l}\text { 平洕 } \\
\text { 氣泡むり }\end{array}$ & $\begin{array}{l}\text { 㘣形間澱㱠 } \\
\text { 完全 } \\
11-12 \mathrm{~mm}\end{array}$ \\
\hline H 3 & 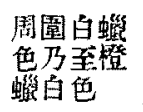 & 稳々急峻 & $\begin{array}{l}\text { 水口は點狀孔 } \\
\text { 虎口部は一段高々 } \\
\text { 隆起寸 }\end{array}$ & $\begin{array}{l}\text { 三重の色柇同 } \\
\text { 心[⿶] }\end{array}$ & $\begin{array}{l}\text { 不明瞭の細かき } \\
\text { 灌䅨放射線 }\end{array}$ & 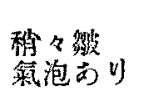 & 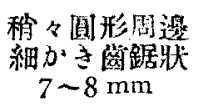 \\
\hline H 4 & $\begin{array}{l}\text { 白的面色乃 } \\
\text { 至白色 }\end{array}$ & 急崚 & 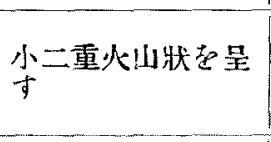 & な & 數佟の放射線 & 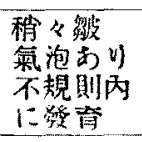 & 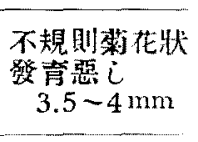 \\
\hline H 5 & $\begin{array}{l}\text { 帶橙黄蜭 } \\
\text { 色 }\end{array}$ & $\begin{array}{l}\text { 倯々隆起 } \\
\text { 部は } \\
\text { 急骖直立 }\end{array}$ & 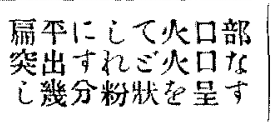 & 色䎢的同心四 & 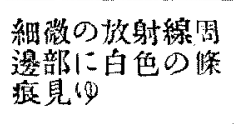 & $\begin{array}{l}\text { 平滑 } \\
\text { 氧泡めり }\end{array}$ & 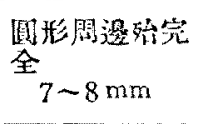 \\
\hline H 6 & 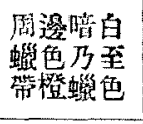 & 㮐々隆起 & 低国錐の頂點㕱 & 同上 & 細溦の放射線 & 同上 & $\begin{array}{l}\text { 同上 } \\
\text { 值德 } \\
\quad 7.5 \sim 8 \mathrm{~mm}\end{array}$ \\
\hline H 7 & 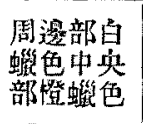 & 急峻 & 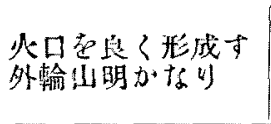 & 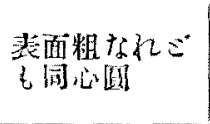 & 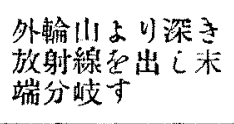 & $\begin{array}{l}\text { 大體平滑 } \\
\text { 氣泡多亡 }\end{array}$ & 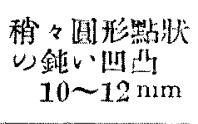 \\
\hline $\mathrm{H} \quad 8$ & 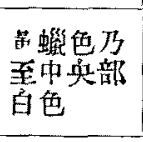 & $\begin{array}{l}\text { 屚平牛分 } \\
\text { 隆起 }\end{array}$ & 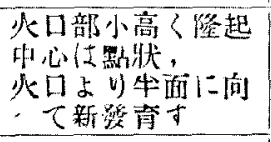 & 标i & 不規则なる放射 & $\begin{array}{l}\text { 平搰 } \\
\text { 氮泡むり }\end{array}$ & 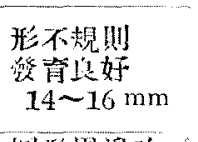 \\
\hline H 9 & 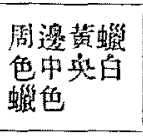 & 堡加隆起 & $\begin{array}{l}\text { 火口部は僅かに點 } \\
\text { 邪低牛月形 }\end{array}$ & 色柇闹心目I & 細微の放訝線 & 同上 & 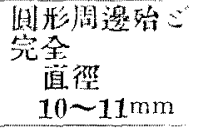 \\
\hline H 10 & 白色斱狀 & 極的七急 & 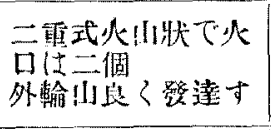 & $\begin{array}{l}\text { 火口部に首狀 } \\
\text { の同心国 }\end{array}$ & 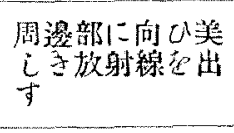 & 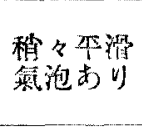 & 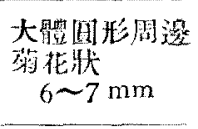 \\
\hline $\mathrm{H} 11$ & 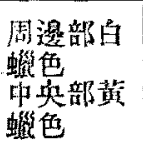 & 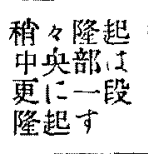 & $\begin{array}{l}\text { 火口暗に不規則に } \\
\text { 高?隆起す }\end{array}$ & 色彩的同心因 & 淺刍暴㭗放射線 & 本 溜 & 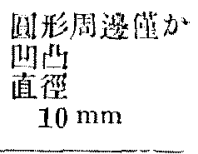 \\
\hline
\end{tabular}




\begin{tabular}{|c|c|c|c|c|c|c|c|}
\hline H 12 & 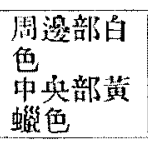 & 急峻 & 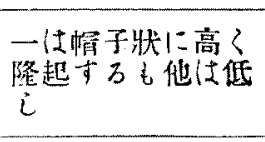 & 同 前 & $\begin{array}{l}\text { 周棌部に整條の } \\
\text { 放射線を出已更 } \\
\text { に分岐寸 }\end{array}$ & $\begin{array}{l}\text { 平滑 } \\
\text { 州泡あり }\end{array}$ & $\begin{array}{l}\text { 国形周邀僅加 } \\
\text { 出入完全 } \\
7 \mathrm{~mm}\end{array}$ \\
\hline II 14 & 黄的落色 & $\begin{array}{l}\text { 共平厚く } \\
\text { 隆起 }\end{array}$ & 火口部稍々原落寸 & $\begin{array}{l}\text { 二重の色粚同 } \\
\text { 心[1] }\end{array}$ & 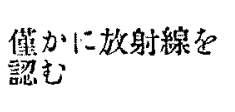 & 同上 & $\begin{array}{l}\text { 正圆形周遑 } \\
\text { 完全 } \\
7 \sim 8 \mathrm{~mm}\end{array}$ \\
\hline If 15 & 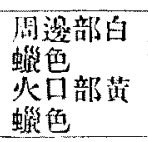 & $\begin{array}{l}\text { 原平必口 } \\
\text { 部か。可か } \\
\text { に隆起 }\end{array}$ & 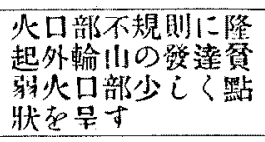 & $\begin{array}{l}\text { 十整ケの美i } \\
\text { い色柇同心圆 }\end{array}$ & 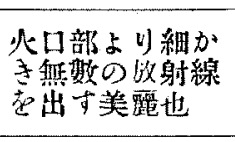 & 同上 & $\begin{array}{l}\text { 国珠周罯始 } \\
\text { 完全 } \\
12 \mathrm{~mm}\end{array}$ \\
\hline II 16 & 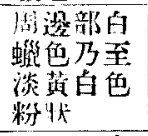 & $\begin{array}{l}\text { 疤平偘か } \\
\text { 愿味有 } \\
\text { 寸 }\end{array}$ & 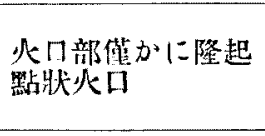 & $\begin{array}{l}\text { 三重の不明瞭 } \\
\text { 方る凹形同心 } \\
\text { 闵 }\end{array}$ & 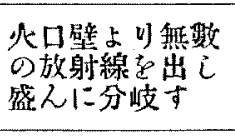 & 阿上 & $\begin{array}{l}\text { 正国形周遈 } \\
\text { 完全 } \\
\quad 10 \sim 11 \mathrm{~mm}\end{array}$ \\
\hline It 17 & 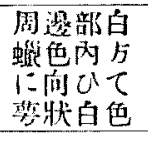 & 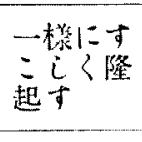 & 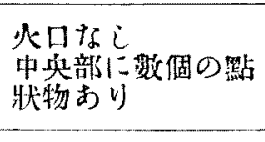 & な & $\begin{array}{l}\text { 周鰛部に僅がの } \\
\text { 放射線 }\end{array}$ & 闰上 & 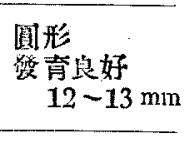 \\
\hline It 18 & " & " & " & " & $\prime \prime$ & " & " \\
\hline H 19 & 白色噃狀 & 稍々傾斜 & 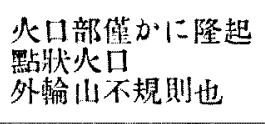 & $\begin{array}{l}\text { 不規则なる同 } \\
\text { 心圆 }\end{array}$ & 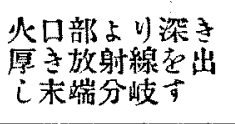 & 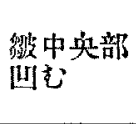 & 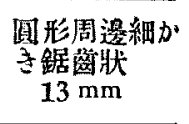 \\
\hline H 20 & 同上 & 急 峻 & 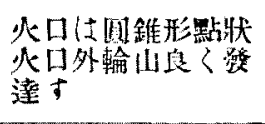 & $\begin{array}{l}\text { 不規則なる同 } \\
\text { 心圆 }\end{array}$ & 同上 & 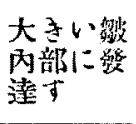 & $\begin{array}{l}\text { 凰形周櫋不規 } \\
\text { 則鋸图 } \\
14 \mathrm{~mm}\end{array}$ \\
\hline H 21 & 同上 & 同上 & 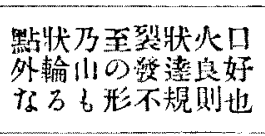 & $\begin{array}{l}\text { 不規則蛇腹狀 } \\
\text { 同心圆 }\end{array}$ & 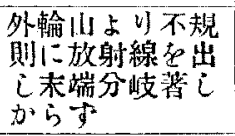 & $\begin{array}{l}\text { 著己々内 } \\
\text { 部に桵青 } \\
\text { 寸 }\end{array}$ & $\begin{array}{l}\text { 形不規制細か } \\
\text { き鋸兽狀 } \\
\quad \text { 11 13 mm }\end{array}$ \\
\hline II 22 & 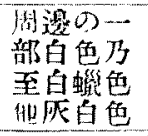 & $\begin{array}{l}\text { 急骖中央 } \\
\text { 部澼斥 }\end{array}$ & 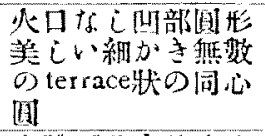 & $\begin{array}{l}\text { terrace 狀闹心 } \\
\text { 圆 }\end{array}$ & 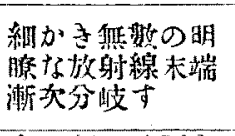 & 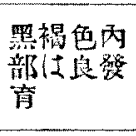 & $\begin{array}{l}\text { 形不規刡周瀑 } \\
\text { 不規則完全 } \\
25 \sim 28 \mathrm{~mm}\end{array}$ \\
\hline H 23 & 白色粗面 & $\begin{array}{l}\text { 藷しく急 } \\
\text { 峻 }\end{array}$ & 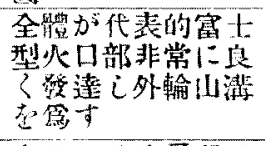 & 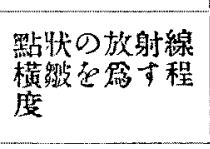 & 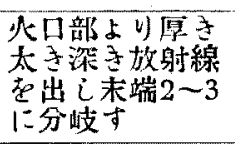 & 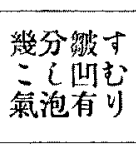 & $\begin{array}{l}\text { 大體圆形周澷 } \\
\text { 鋸遥狀 } \\
8 \mathrm{~mm}\end{array}$ \\
\hline II 24 & 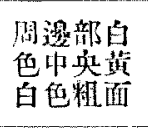 & $\begin{array}{l}\text { 恶平 } \\
\text { 必口部稍 } \\
\text { 隆起 }\end{array}$ & 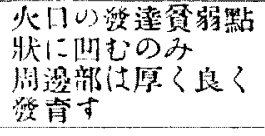 & 闰上 & 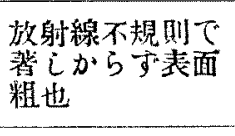 & 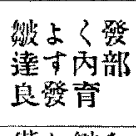 & $\begin{array}{l}\text { 大賗国形周邊 } \\
\text { 不規則出入 } \\
\text { 16 17 } \mathrm{mm}\end{array}$ \\
\hline H 25 & 淡素白色 & $\begin{array}{l}\text { 厦平 } \\
\text { 火日部の } \\
\text { み隆起 }\end{array}$ & 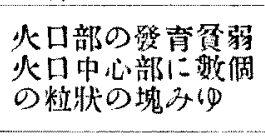 & $+2 \quad i$ & $\begin{array}{l}\text { 放射線は細か子 } \\
\text { 粗狀走呈寸 } \\
\text { 不規则也 }\end{array}$ & 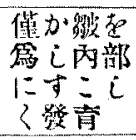 & $\begin{array}{c}\text { 圆形周漫不規 } \\
\text { 则細鋸离状 } \\
15 \mathrm{~mm}\end{array}$ \\
\hline II 26 & 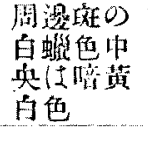 & $\begin{array}{l}\text { 简平 } \\
\text { 火口部は } \\
\text { 粒狀突起 }\end{array}$ & 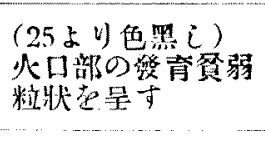 & $\begin{array}{l}\text { 不規则なっ同 } \\
\text { 心圆 }\end{array}$ & 同上 & $\begin{array}{l}\text { 中央部細 } \\
\text { 加寻鳞 }\end{array}$ & 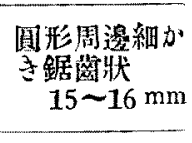 \\
\hline It 28 & 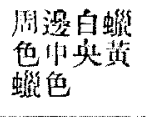 & 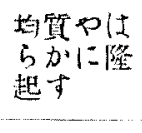 & 兆口部呫状に师屯 & な $i$ & 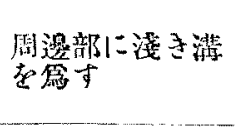 & $\begin{array}{l}\text { 本滑 } \\
\text { 氣泡おり }\end{array}$ & $\begin{array}{c}\text { 闻形周罯嚾か } \\
\text { 出入おり } \\
14 \mathrm{~mm}\end{array}$ \\
\hline Il 31 & 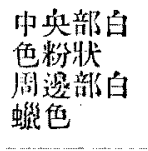 & 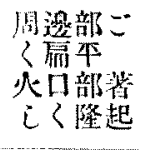 & 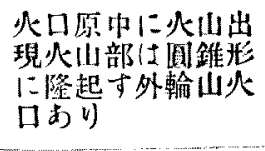 & 色柇的同心叫] & 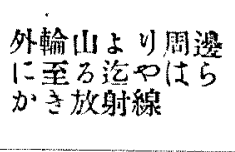 & 同上 & $\begin{array}{l}\text { 正圆形周漫㱠 } \\
\text { 完全 } \\
\quad 11 \mathrm{~mm}\end{array}$ \\
\hline H 32 & 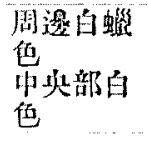 & 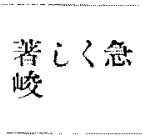 & $\begin{array}{l}\text { 火口部粘牞に隆起 } \\
\text { 他は一寸筫万 }\end{array}$ & $\begin{array}{l}\text { 不規則なる同 } \\
\text { 心自 } 2 \text { ケ }\end{array}$ & 不规則なる放射 & 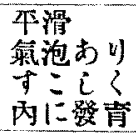 & 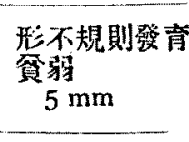 \\
\hline
\end{tabular}




\begin{tabular}{|c|c|c|c|c|c|c|c|}
\hline H 33 & 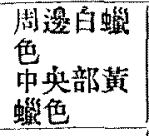 & 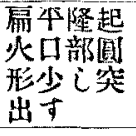 & 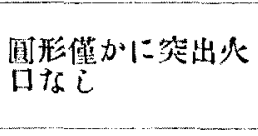 & 色彩的同心圓 & 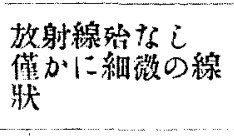 & $\begin{array}{l}\text { 本滑 } \\
\text { 氣泡あり }\end{array}$ & $\begin{array}{l}\text { 回形周㴗完全 } \\
9 \mathrm{~mm}\end{array}$ \\
\hline H 34 & $\begin{array}{l}\text { 全體白色 } \\
\text { 翻狀 }\end{array}$ & $\begin{array}{l}\text { 檿く隆起 } \\
\text { 粗面 }\end{array}$ & 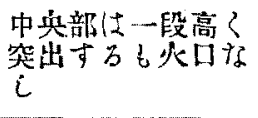 & $\begin{array}{l}\text { 不婗則なっ數 } \\
\text { 重の同心圆 }\end{array}$ & 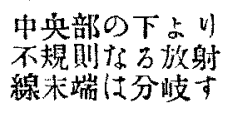 & 紴 & 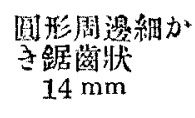 \\
\hline H 35 & $\begin{array}{l}\text { 舍易喑赤 } \\
\text { 褐色 }\end{array}$ & 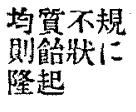 & 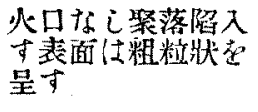 & $+i$ & 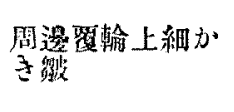 & 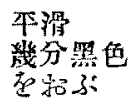 & 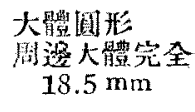 \\
\hline H 36 & $\begin{array}{l}\text { 阔要部白 } \\
\text { 亞色 } \\
\text { 奥部淡 } \\
\text { 兴色 }\end{array}$ & $\begin{array}{l}\text { 低圆錐狀 } \\
\text { 隆起卞 }\end{array}$ & $\begin{array}{l}\text { 大いさ } 6 \mathrm{~mm} \text { の火 } \\
\text { 口を有し外輸山は } \\
\text { 不規则な數個の峰 } \\
\text { こなる }\end{array}$ & 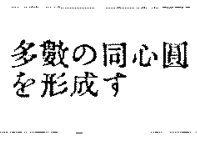 & 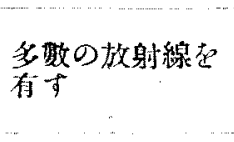 & & $\begin{array}{l}\text { 国形 } \\
\text { 出入有吸 } \\
\quad 16 \sim 20 \mathrm{~mm}\end{array}$ \\
\hline H 37 & $\begin{array}{l}\text { 孚白黄蛇 } \\
\text { 色 }\end{array}$ & 急哂 & 水口なし & is $C$ & な $i$ & & $\begin{array}{l}\text { [1]] 形 } \\
25 \mathrm{~mm}\end{array}$ \\
\hline H 122 & 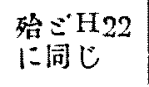 & & & & & & \\
\hline
\end{tabular}

註：II 36 及び H 37 は则に室温に100日放置ぜるしのである。

(3) 巨大聚落 (其二).

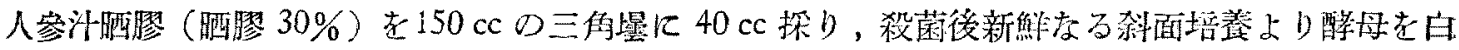

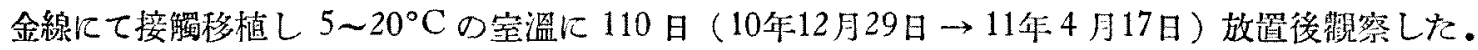

\begin{tabular}{|c|c|c|c|c|c|c|c|c|}
\hline \multicolumn{2}{|c|}{ 菌符號發育の程度 } & \multirow{2}{*}{ 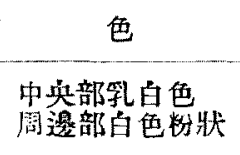 } & \multirow{2}{*}{ 傾 斜 } & \multirow{2}{*}{$\mid \begin{array}{ll}\text { 火 } & \text { 小 } \\
\text { 無己 }\end{array}$} & 同心圆 & \multirow{2}{*}{ 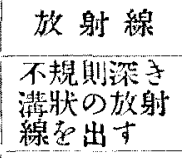 } & \multirow{2}{*}{ 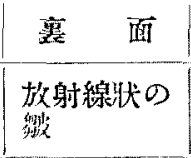 } & \multirow{2}{*}{\begin{tabular}{|c} 
其 他 \\
秢々国錐形 \\
$10.0 \mathrm{~mm}$
\end{tabular}} \\
\hline H 1 & 息 & & & & 然 $i$ & & & \\
\hline H 2 & 稍々劣る & 黄蠟色 & 甚だ急湈 & $" \prime$ & $" \prime$ & 無 $i$ & $\begin{array}{l}\text { 滑也內部に } \\
\text { 少しく發青 }\end{array}$ & $\begin{array}{l}\text { 大䯏形 } \\
\text { 丘狀粗面 } \\
5.0 \mathrm{~mm}\end{array}$ \\
\hline H 3 & 惡 $i$ & $\prime \prime$ & 僅が隆起 & 點爿水口 & $\prime \prime$ & $\prime \prime$ & 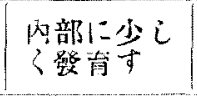 & $\begin{array}{l}\text { 不規则 } \\
2.0 \mathrm{~mm}\end{array}$ \\
\hline H 4 & 瑟 $i$ & 白經色 & 無 $i$ & 策 己 & $\prime \prime$ & $\prime \prime$ & 闹上 & $\begin{array}{l}\text { 不規则 } \\
1.5 \mathrm{~mm}\end{array}$ \\
\hline $\mathrm{H} \quad 5$ & 秴々劣る & 黄蜼色 & 甚げ急骖 & $\prime \prime$ & $\prime \prime$ & $\prime \prime$ & 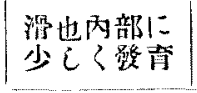 & $\begin{array}{c}\text { 大䎪㭵形粗面 } \\
5.0 \mathrm{~mm}\end{array}$ \\
\hline H 6 & 息 & 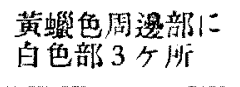 & $" \prime$ & $\prime \prime$ & $\because \prime$ & $" \prime$ & $\prime \prime$ & $\begin{array}{r}\text { 大䯏夙形 } \\
8.0 \mathrm{~mm}\end{array}$ \\
\hline H 7 & 稍々劣万 & 黄白跑色 & 急 峻 & $\prime \prime$ & $\prime \prime$ & 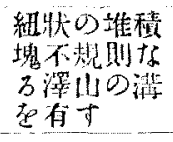 & 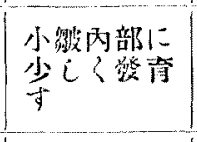 & $\begin{array}{c}\text { 㮐々四錐形 } \\
6.0 \mathrm{~mm}\end{array}$ \\
\hline H 8 & 是 & 白也粉狀 & $" \prime$ & $\prime \prime$ & $" \prime$ & 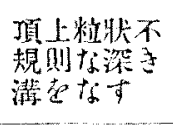 & 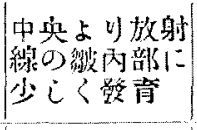 & 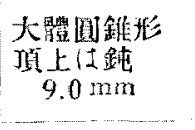 \\
\hline H 9 & 是 & 黄蝯色 & $\prime \prime$ & $\prime \prime$ & $\prime \prime$ & 無 $i$ & 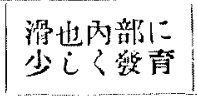 & $\begin{array}{l}\text { 回䧾形表面粗 } \\
9.0 \mathrm{~mm}\end{array}$ \\
\hline $\mathrm{H} 10$ & 桜々劣る & $" \prime$ & 苜だ急峻 & $\prime \prime$ & $\prime \prime$ & 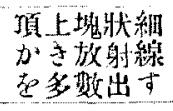 & 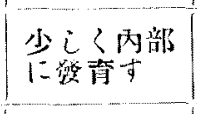 & 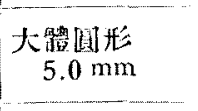 \\
\hline H 11 & $\prime \prime$ & $\prime \prime$ & 念 㥖 & $\prime \prime$ & $\prime \prime$ & 焦 $i$ & $\begin{array}{l}\text { 滑也冈部に } \\
\text { 少しく墢店 }\end{array}$ & $\begin{array}{c}\text { 国形粗面粗将 } \\
6.0 \mathrm{~mm}\end{array}$ \\
\hline
\end{tabular}




\begin{tabular}{|c|c|c|c|c|c|c|c|c|}
\hline II 12 & 劣 万 & 黄䱺色 & 甚げ念峻 & 無し & 無 $\iota$ & 無 $i$ & $\begin{array}{l}\text { 滑也內部に } \\
\text { 少しく發育 }\end{array}$ & $\begin{array}{c}\text { 大體这形 } \\
\text { 表颛 } \\
4.0 \mathrm{~mm}\end{array}$ \\
\hline II 14 & 稄々少万 & " & 急 崚 & $" 1$ & $\begin{array}{l}\text { 微がに } \\
\text { の同心圆 }\end{array}$ & $"$ & "l & $\begin{array}{l}\text { 圆雓形祘瀑 } \\
\text { 全 } \\
6.0 \mathrm{~mm}\end{array}$ \\
\hline II 15 & Lit & 黄白蠳色 & $" \prime$ & " & 無 $i$ & 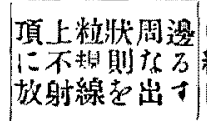 & 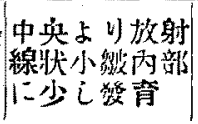 & $\begin{array}{c}\text { 大髅圆錐形 } \\
9.0 \mathrm{~mm}\end{array}$ \\
\hline II 16 & It & 黄蛝色 & "' & $\prime \prime$ & $\begin{array}{l}\text { 微がに一问 } \\
\text { の闰心圓 }\end{array}$ & 無 $i$ & $\begin{array}{l}\text { 滑地內部に } \\
\text { 少七發青 }\end{array}$ & 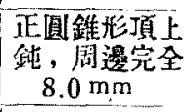 \\
\hline H 17 & 甚大堤 & 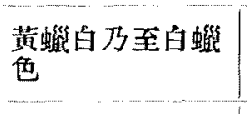 & 低く隆起 & $\prime \prime$ & 無 $i$ & 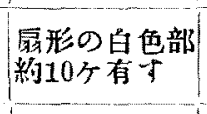 & 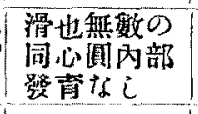 & $\begin{array}{c}\text { 大體圆形 } \\
17.0 \mathrm{mra}\end{array}$ \\
\hline HI 18 & $" \prime$ & $"$ & $\prime \prime$ & " & $" \prime$ & $\begin{array}{l}\text { 属形の㫫色 } \\
\text { 部數ヶ有守 }\end{array}$ & " & $\begin{array}{l}\text { 圆形 } \\
\quad 15.0 \mathrm{~mm}\end{array}$ \\
\hline II 19 & 稍々少万 & 罱蝠色乃至百色 & 急 峻 & $" 1$ & " & 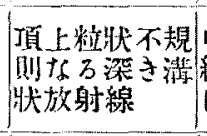 & 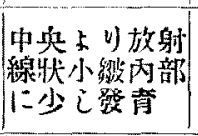 & $\begin{array}{r}\text { 大體国形 } \\
7.0 \mathrm{~mm}\end{array}$ \\
\hline II 20 & 良 & 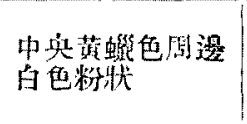 & $\prime \prime$ & $\prime \prime$ & $"$ & 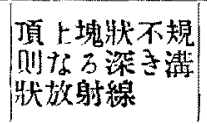 & 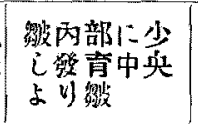 & $\begin{array}{c}\text { 大骷圆錐形 } \\
11.0 \mathrm{~mm}\end{array}$ \\
\hline II 21 & $" \prime$ & 黄白酸色 & $" \prime$ & 11 & $\prime \prime$ & $\mid \begin{array}{l}\text { 留上塊狀組 } \\
\text { 狀の放射線 } \\
\text { 出出す }\end{array}$ & $\begin{array}{l}\text { 盛漫に小解 } \\
\text { 有り }\end{array}$ & $\begin{array}{c}\text { 大體国雓形 } \\
8.0 \mathrm{~mm}\end{array}$ \\
\hline II 22 & 甚だ是好 & $\begin{array}{l}\text { 中奥部灰白色 } \\
\text { 周沮白蜳色 }\end{array}$ & 倠く臸赸 & $\prime \prime$ & $\begin{array}{l}\text { 微かに二用 } \\
\text { の同心圓 }\end{array}$ & 無 $i$ & 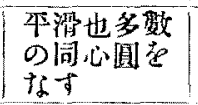 & $\begin{array}{c}\text { 大體国形 } \\
30.0 \mathrm{~mm}\end{array}$ \\
\hline H 23 & 惡 $i$ & 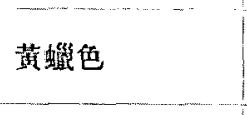 & 甚だ急骖 & " & 無 $i$ & 1 & 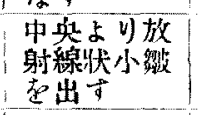 & $\begin{array}{l}\text { 大體闻形 } \\
\text { 表面粗 } \\
3.5 \mathrm{~mm}\end{array}$ \\
\hline H 24 & 是 & 白色数状 & 急 骖 & $" 1$ & it & 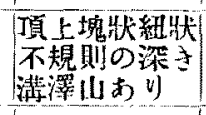 & $\begin{array}{l}\text { 中奥より放 } \\
\text { 射線の微 }\end{array}$ & $\begin{array}{c}\text { 大體国錐形 } \\
\quad 8.0 \mathrm{~mm}\end{array}$ \\
\hline H 25 & $\prime \prime$ & " & 隆 起 & " & $" \prime$ & 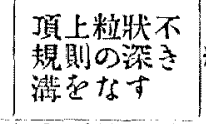 & 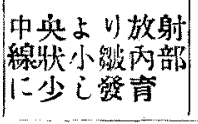 & 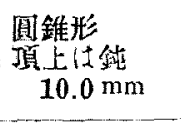 \\
\hline II 26 & $\prime \prime$ & 黄宁蝐妑 & 总 峻 & " & " & 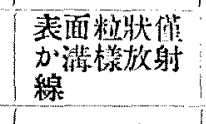 & II & $\begin{array}{l}\text { 大體国形丘狀 } \\
\quad 9.0 \mathrm{~mm}\end{array}$ \\
\hline II 28 & 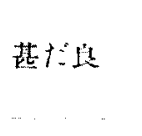 & 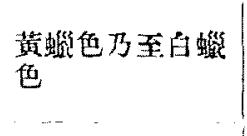 & 隆 起 & $" \prime$ & ' & 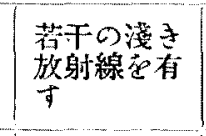 & $\begin{array}{l}\text { 放射線漛小 } \\
\text { 鼣多多数同 } \\
\text { 心圆 }\end{array}$ & $\begin{array}{c}\text { 大體国形 } \\
\text { 粰花狀 } \\
17.0 \mathrm{~mm}\end{array}$ \\
\hline II 31 & 稍々劣万 & 䒚略色 & 急 峻 & $\prime \prime$ & $\begin{array}{l}\text { 微かに二- } \\
\text { の同心时 }\end{array}$ & 䑾 $i$ & $\begin{array}{l}\text { 滑也內部に } \\
\text { 少えく發有 }\end{array}$ & 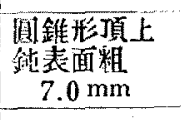 \\
\hline II 32 & 芘犬゙俧 & "I & & "I & 無 $i$ & $\prime \prime$ & 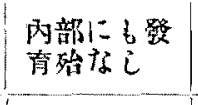 & $\begin{array}{l}\text { 粒状 } \\
1.5 \mathrm{~mm} \\
\end{array}$ \\
\hline II 33 & 秒々步る & " & 急 峻 & $\prime \prime$ & $\begin{array}{l}\text { 微加心一同 } \\
\text { の同心国 }\end{array}$ & 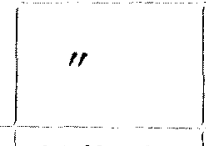 & 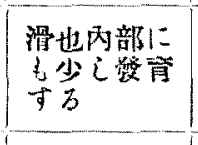 & 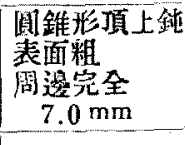 \\
\hline H 34 & " & "' & 范げ笖唆 & " & 無 & 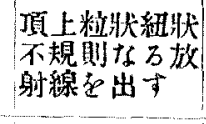 & 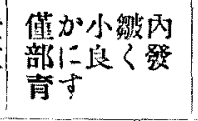 & $\begin{array}{r}\text { 大體圆形 } \\
6.0 \mathrm{~mm}\end{array}$ \\
\hline If 35 & 甚犬゙良好 & 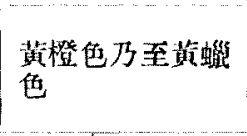 & 蛕 平 & "I & 11 & 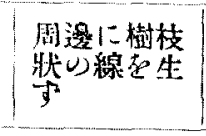 & $\begin{array}{l}\text { 平 㽞 } \\
\text { (瀑性) }\end{array}$ & 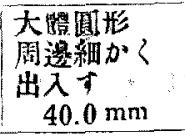 \\
\hline
\end{tabular}




\begin{tabular}{|c|c|c|c|c|c|c|c|c|}
\hline H 36 & $"$ & 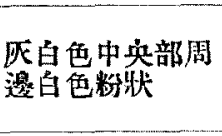 & 砝に厚本 & 澄豆三重 & 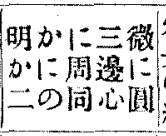 & 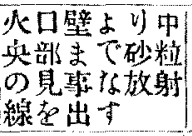 & 平 滑 & 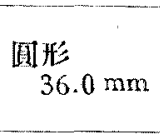 \\
\hline H 37 & 稍々劣ち & 黄蠟色 & 鴙 峻 & 㶵 & $\begin{array}{l}\text { 微かに一同 } \\
\text { の同心国 }\end{array}$ & 無 $i$ & 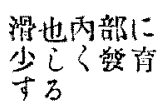 & 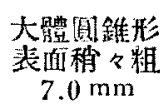 \\
\hline I 122 & 甚代证好 & $\begin{array}{l}\text { 中央部喑灰色 } \\
\text { 周邀部白亞色 }\end{array}$ & $\begin{array}{l}\text { A漫部狺 } \\
\text { 年 } \\
\text { 中央部隆 } \\
\text { 起す }\end{array}$ & 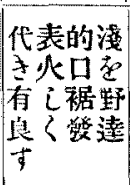 & 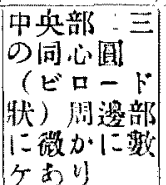 & 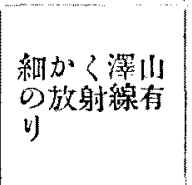 & 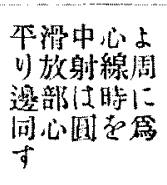 & $\begin{array}{l}\text { 大蹬国形 } \\
32.0 \mathrm{~mm}\end{array}$ \\
\hline
\end{tabular}

6. 分離酵母考味袋に移植せる試驗

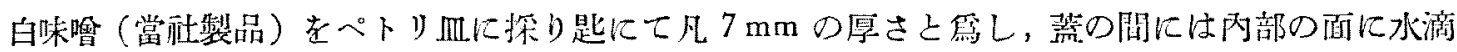

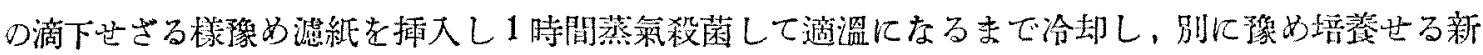

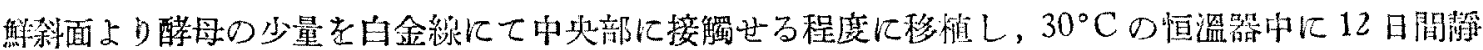
置後取出して發育の状態を觀察した。

\begin{tabular}{|c|c|c|c|c|c|c|c|}
\hline 菌株蕃號 & 色 & 形 & $\begin{array}{l}\text { 大い? } \\
(\mathrm{mm})\end{array}$ & 隆 起 & $\begin{array}{l}\text { 高? } \\
(\mathrm{mm})\end{array}$ & 内部 & 考 \\
\hline H 1 & 溇白色 & 不规则 & 10.0 & 塊 狀 & 7.0 & 發青建好 & 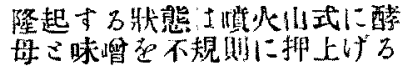 \\
\hline II 2 & 黑褐色 & 殆ミ泪形 & 3.0 & 殆原平 & & & 殆ご表面に發育する \\
\hline H 3 & 艩白色 & 不規則 & 7.0 & 塊 状 & 5.0 & 稍々登育 & 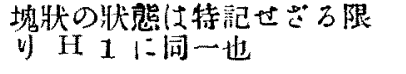 \\
\hline $\mathrm{H} 4$ & $\prime \prime$ & $" 1$ & $5.0 \sim 7.0$ & " & 3.0 & 發肩良好 & \\
\hline H 5 & $"$ & $"$ & 5.0 & 稍扁平 & 2.0 & "l & \\
\hline H 6 & $\prime \prime$ & $" \prime$ & $7.0 \sim 12.0$ & 塊 狀 & 8.0 & 繁春廷好 & 高了德必山狀隆起 \\
\hline II 7 & $" \prime$ & $" \prime$ & $8.0 \sim 9.0$ & " & 5.0 & $\prime \prime$ & \\
\hline H 8 & 黑褐色 & 殆圆形 & 4.0 & 病 平 & & 稍々器笲 & \\
\hline H 9 & $\prime \prime$ & " & $\prime \prime$ & $\prime \prime$ & & " & \\
\hline II 10 & 乳白色 & 不規則 & 6.0 & 塊 狀 & 3.5 & 發青艮好 & \\
\hline $\mathrm{H}_{11}$ & $\prime \prime$ & 稍々四形 & $5.0 \sim 7.0$ & 正 狀 & 2.0 & 稍々墢育 & 隆起部の表西は大體福平也 \\
\hline $\mathrm{H}_{12}$ & $\prime \prime$ & " & 5.0 & $" \prime$ & $\prime \prime$ & & 殆气゙表面に㱩育する \\
\hline II 14 & 黑褐色 & 殆国形 & 2.5 & 沿福本 & & & 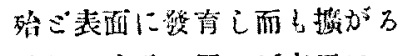 \\
\hline It 15 & 乳白色 & 不規则 & $7.0 \sim 7.5$ & 塊 状 & 2.5 & 發符す & 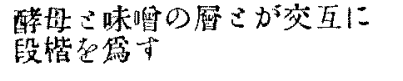 \\
\hline H 16 & 黑褐色 & 稍々圓形 & 2.0 & 殆霞平 & & & 殆ご表面のみ \\
\hline $\mathrm{H} 17$ & $" \prime$ & 圆 形 & $\prime \prime$ & 蛹平 & & & 殆心表面留青 \\
\hline IL 18 & $" \prime$ & " & 3.0 & $" \prime$ & & & 间上 \\
\hline H 19 & 乳白色 & 不規則 & 5.0 & 塊 狀 & 3.0 & 發育跿好 & 酸㹜に隆起 \\
\hline If 20 & $\prime \prime$ & $\prime \prime$ & 7.0 & $" \prime$ & 4.0 & 發青薬圤好 & \\
\hline H 21 & $\prime \prime$ & $" \prime$ & 6.0 & $\prime \prime$ & 6.0 & 聂青证好 & \\
\hline H 22 & 黑䶂色 & & & & & & 發青僅少也 \\
\hline H 23 & 乳白色 & 不規則 & 5.0 & 塊 狀 & 3.5 & 發寈过好 & \\
\hline $\mathrm{H}_{24}$ & $" 1$ & $"$ & 7.0 & " & 4.0 & 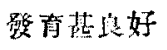 & \\
\hline HI 25 & $\prime \prime$ & $\prime \prime$ & 8.0 & $\prime \prime$ & 6.0 & " & \\
\hline H 26 & $"$ & $" \prime$ & 6.0 & " & 5.0 & $/ \prime$ & \\
\hline
\end{tabular}




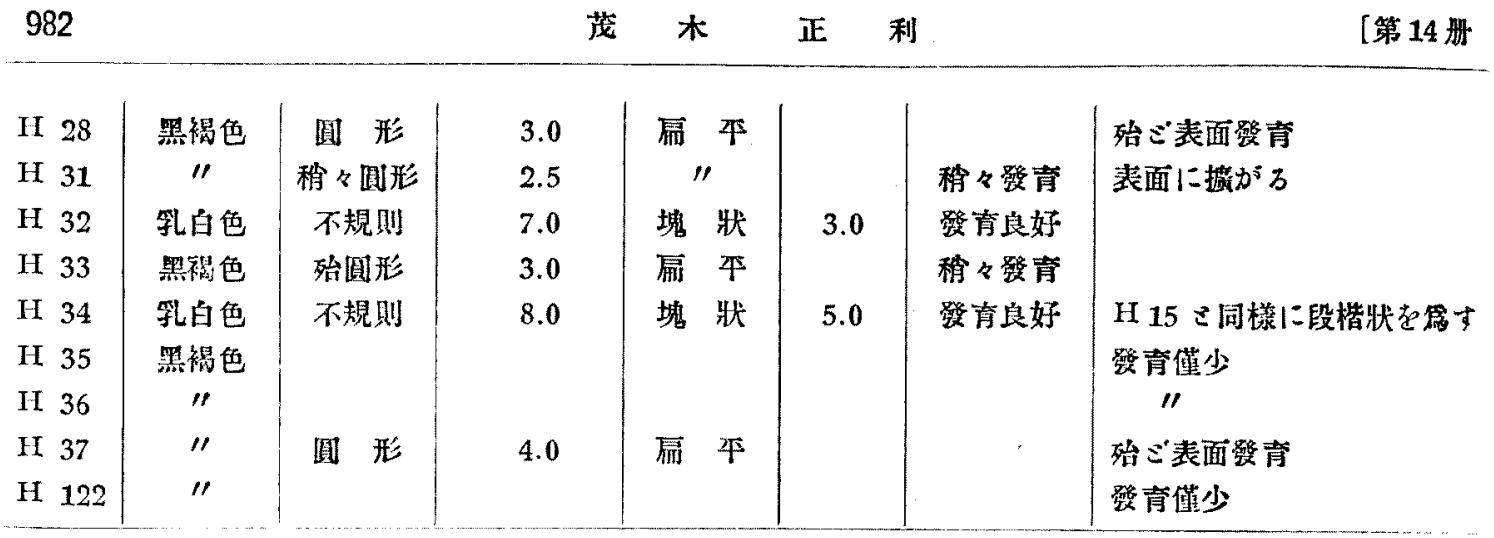


味噲酵杫顯微鏡竄買（2000倍）

猌计培養 (Bllg. $8^{\circ}$ ) $25^{\circ} \mathrm{C} .5 \sim 7$ 日)
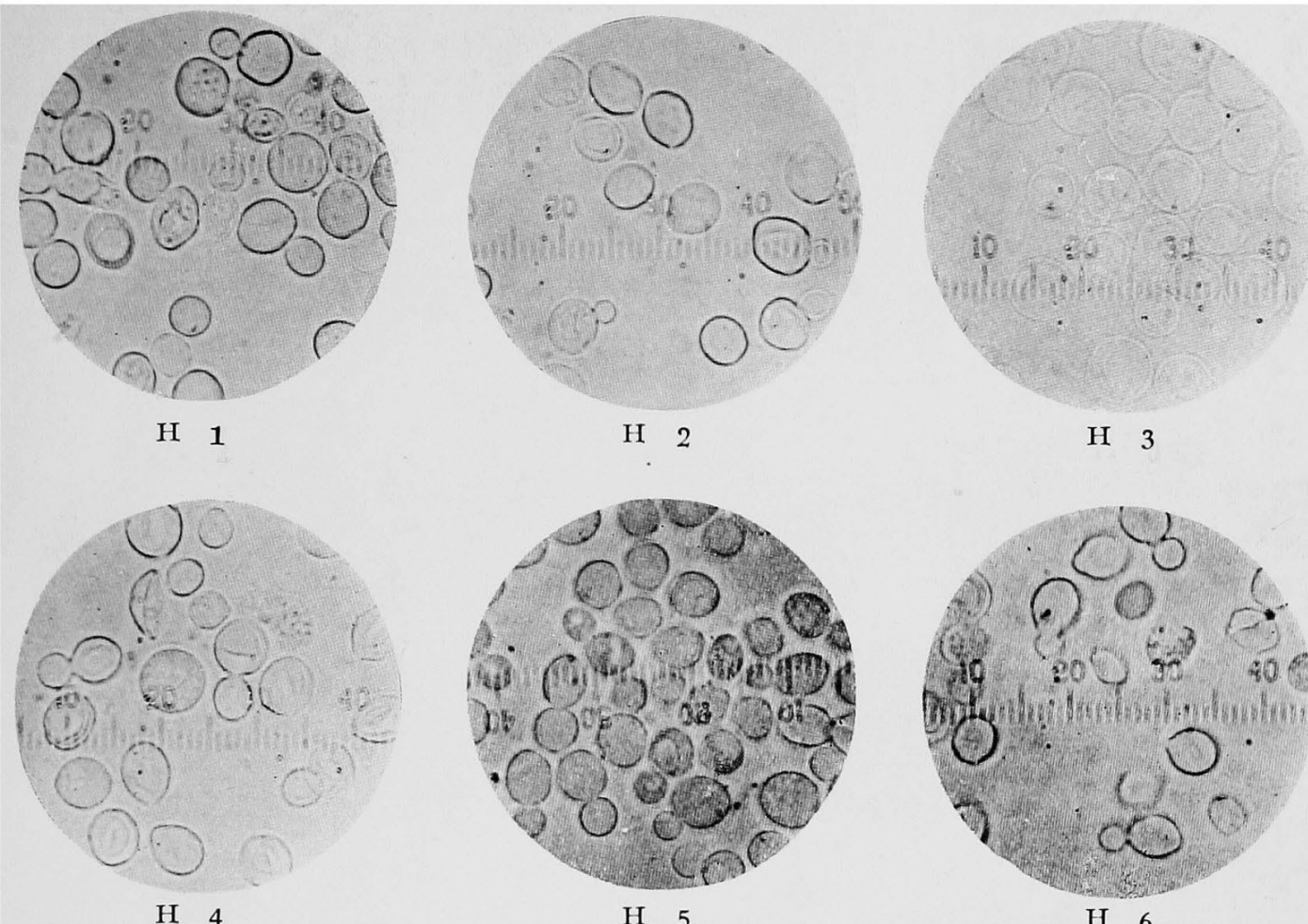

H 4

H 5

Dofy
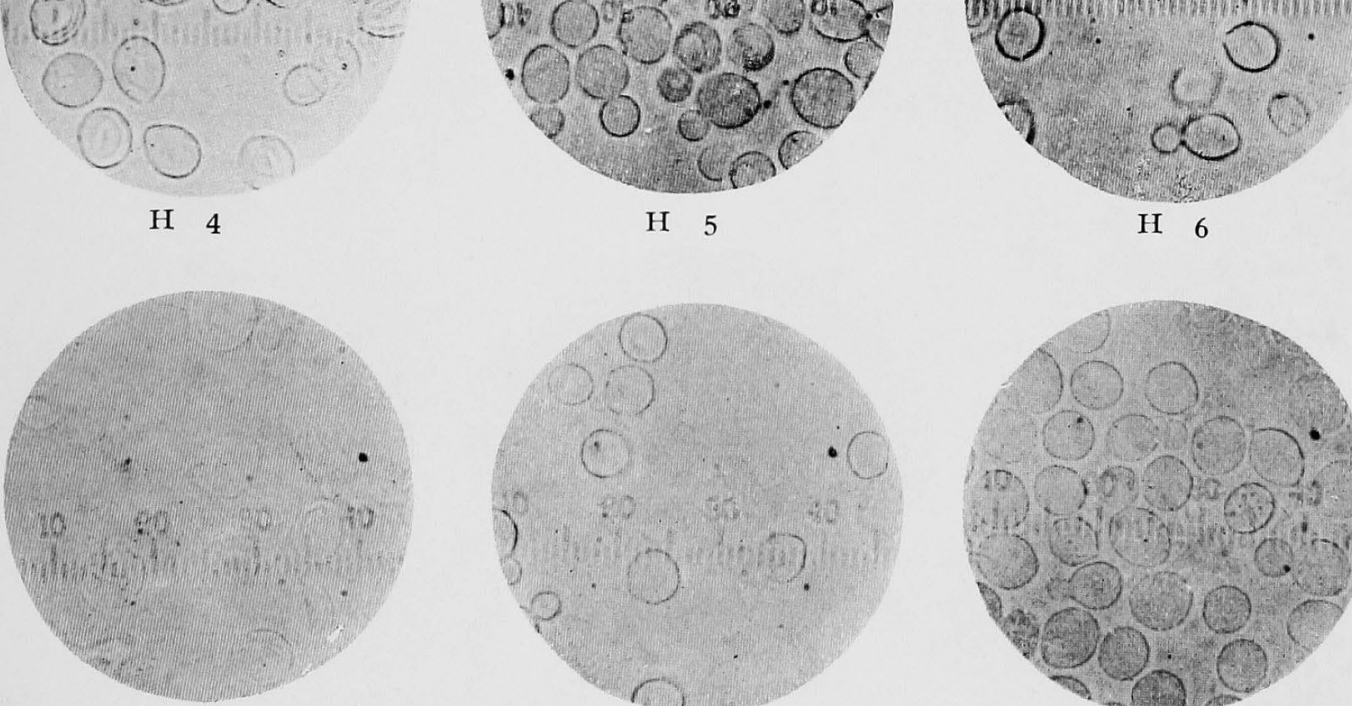

H 7
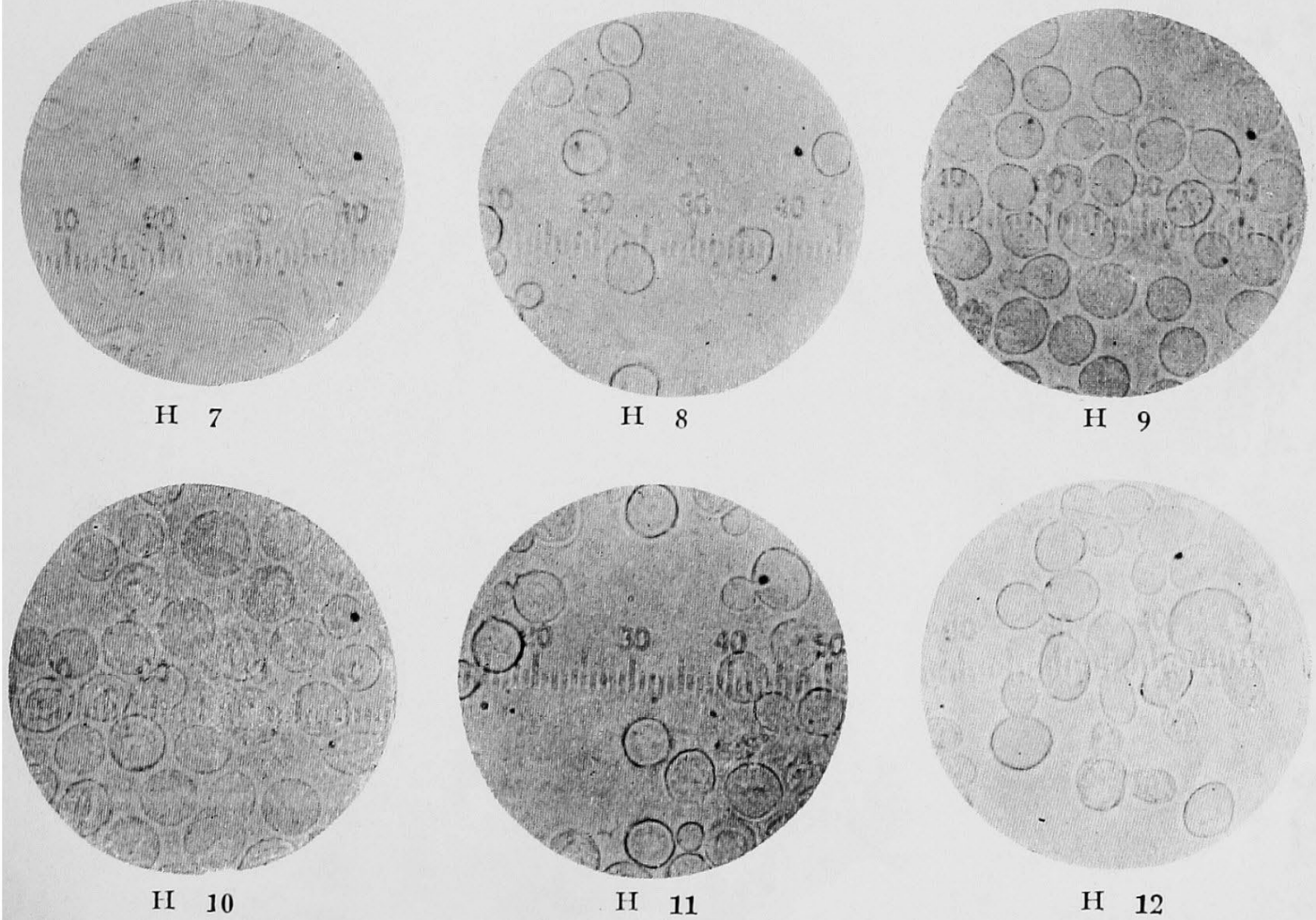


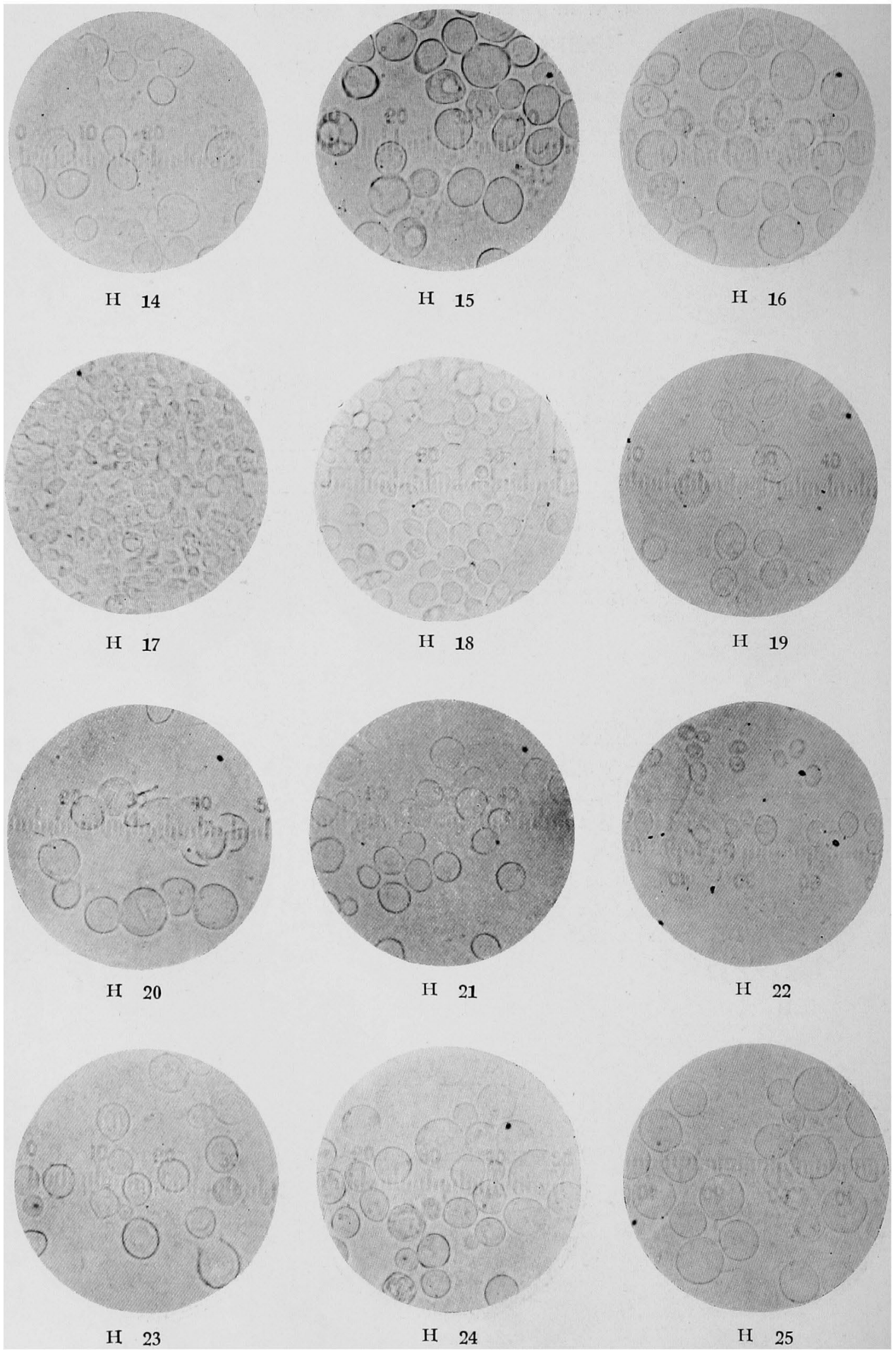



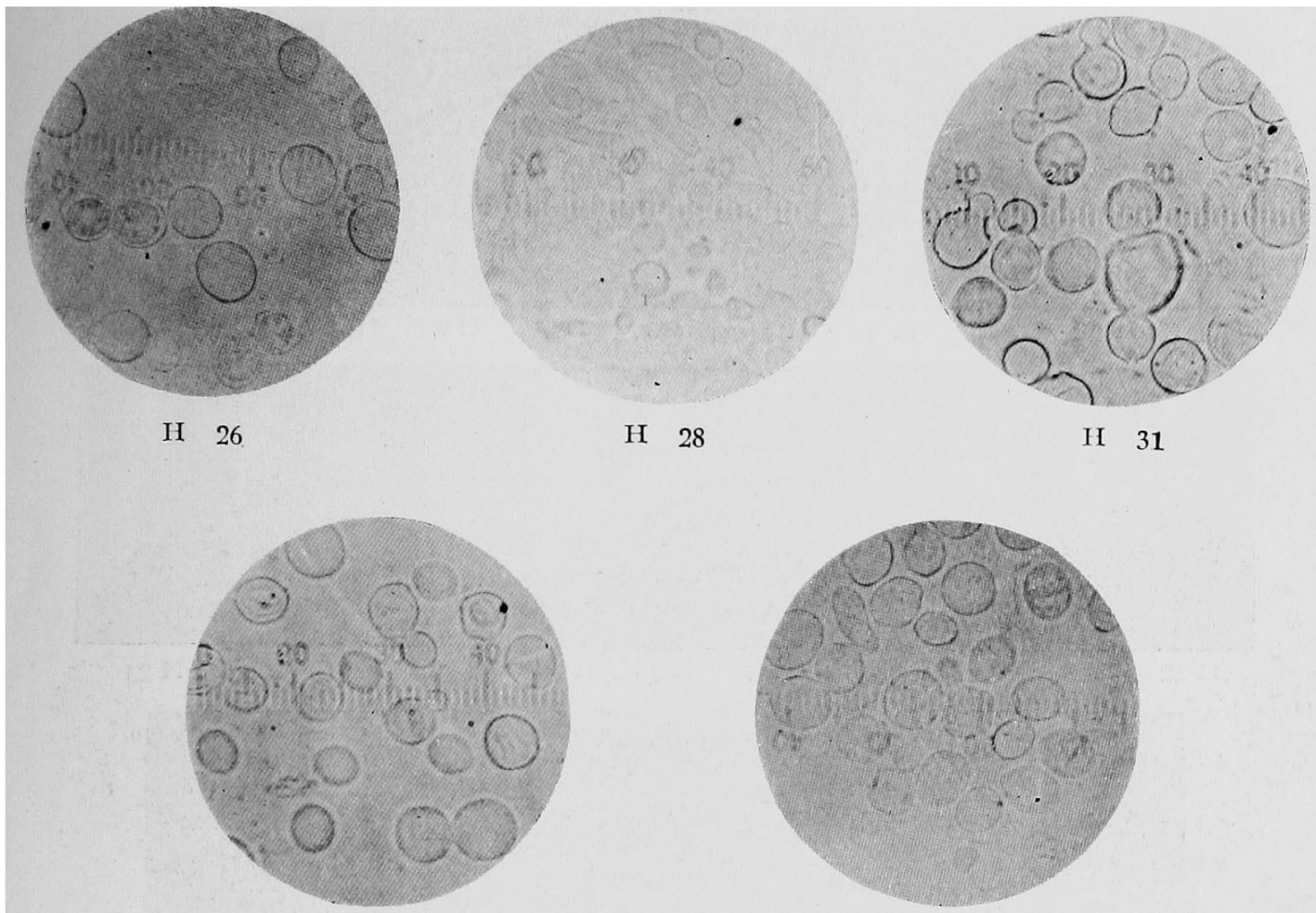

H 32

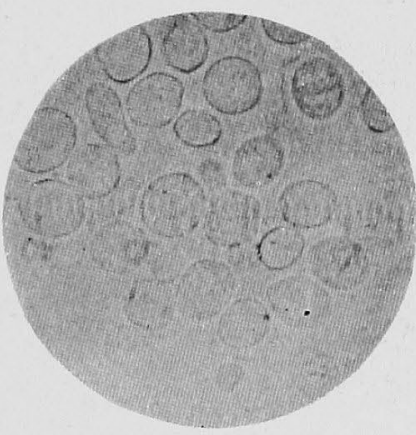

H 33

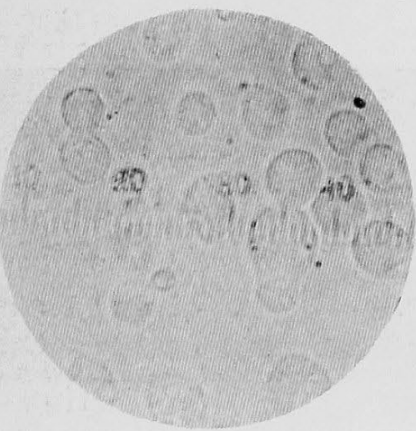

H 34

H 35
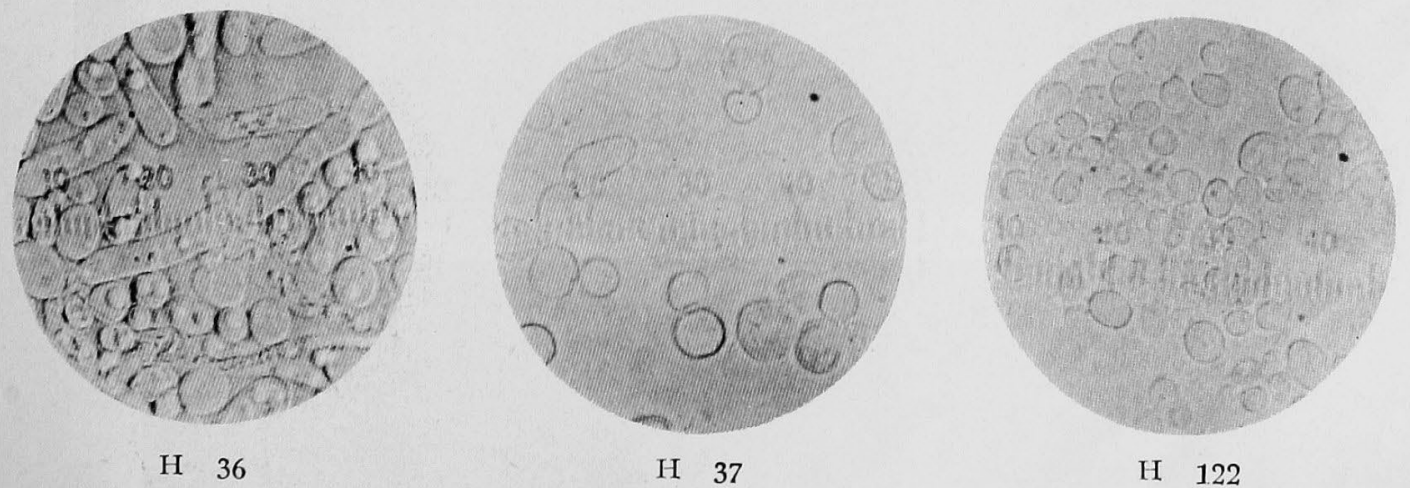
味 噲汒培養
A $30^{\circ} \mathrm{C}: 8$ 日

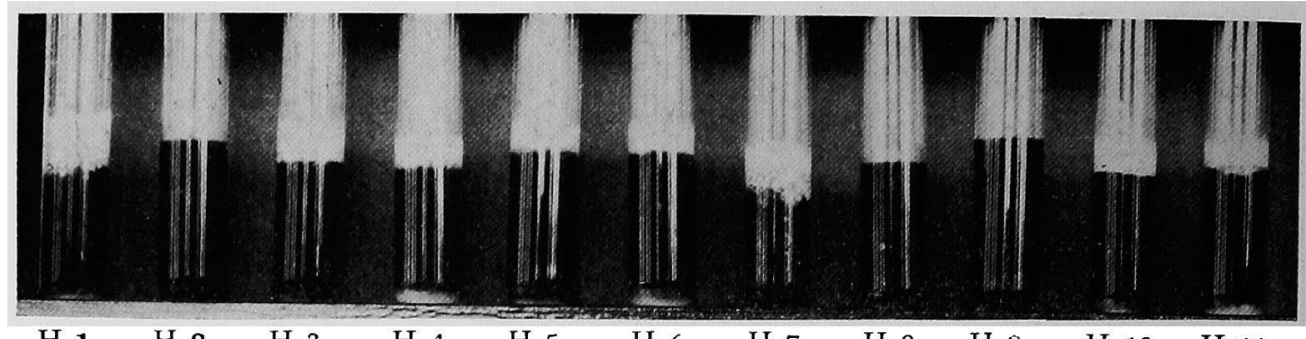

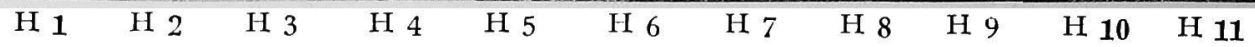

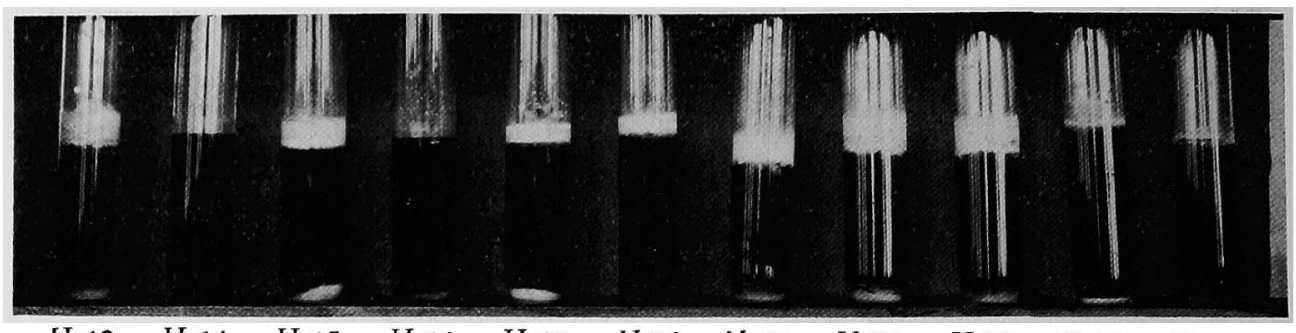
H 12
H 14 H 15
II 16
H 17
H 18
H $19 \quad$ H 20
$\begin{array}{lll}\mathrm{H}_{21} & \mathrm{H}_{22} & \text { H } 23\end{array}$

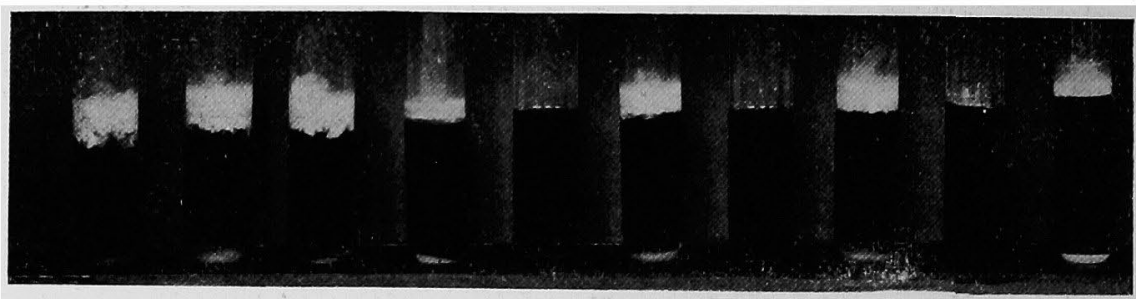

$\begin{array}{lllllllllll}\mathrm{H}_{24} & \mathrm{H}_{2} 2 & \mathrm{H}_{26} & \text { H } 28 & \text { H } 31 & \text { H } 32 & \text { H } 33 & \text { H } 34 & \text { H } 35 & \text { H } 122\end{array}$ B 液
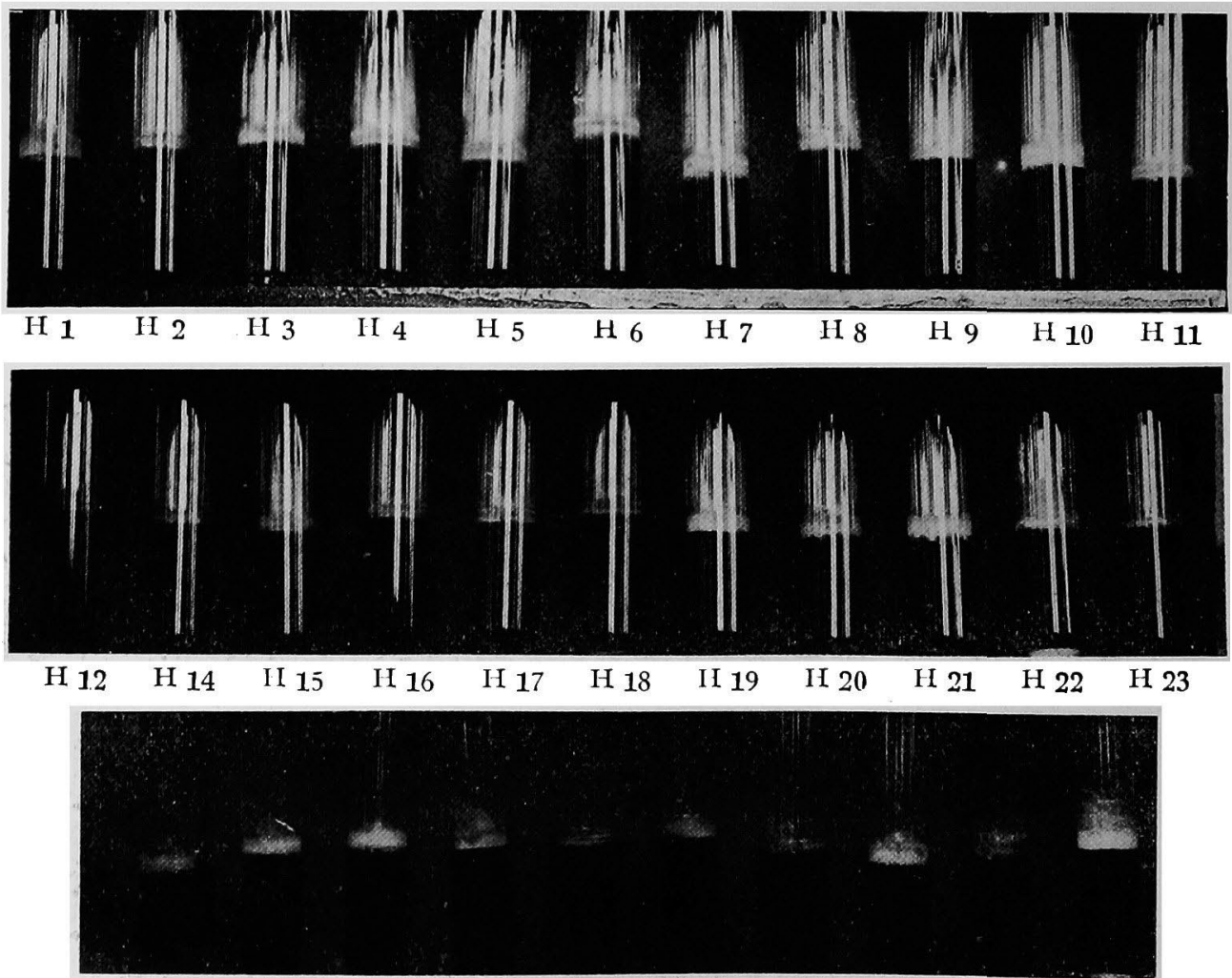

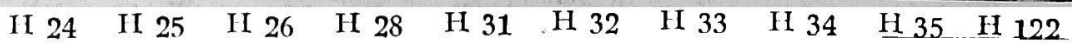


C 液
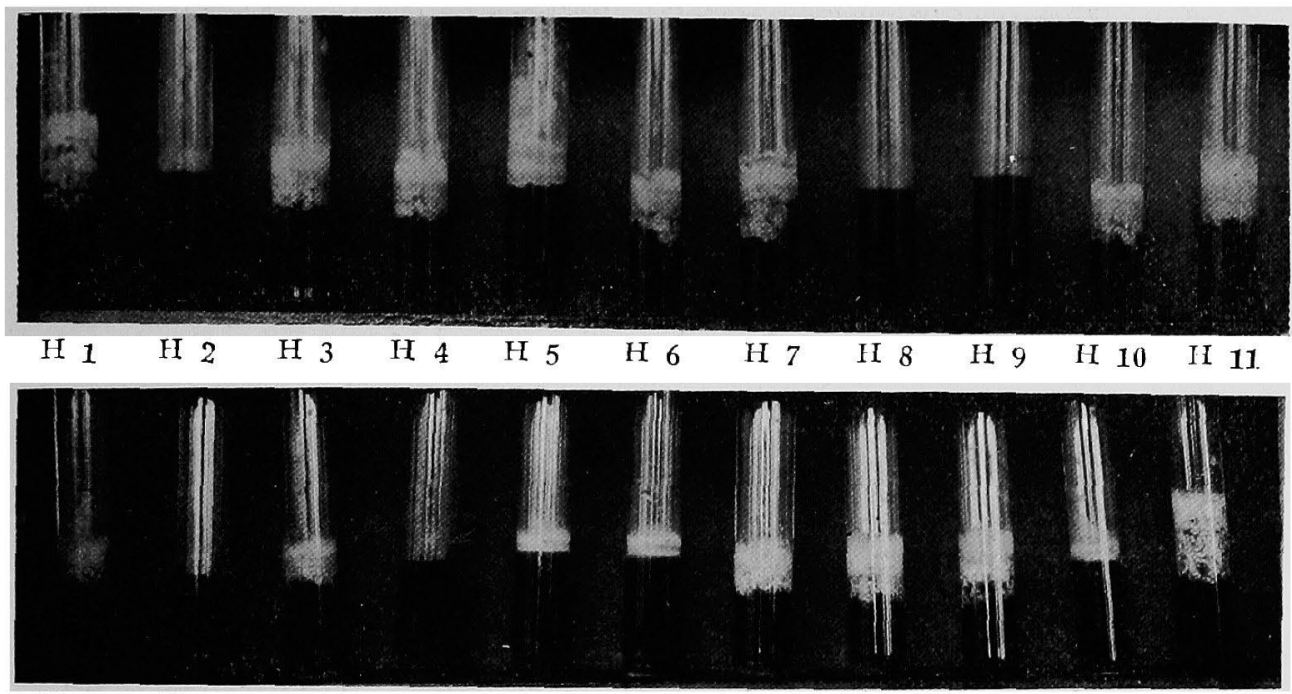

$\begin{array}{llllllllllllllll}\text { H } 12 & \text { H } 14 & \text { H } 15 & \text { II } 16 & \text { H } 17 & \text { H } 18 & \text { H } 19 & \text { H } 20 & \text { II } 21 & \text { H } 22 & \text { II } 23\end{array}$

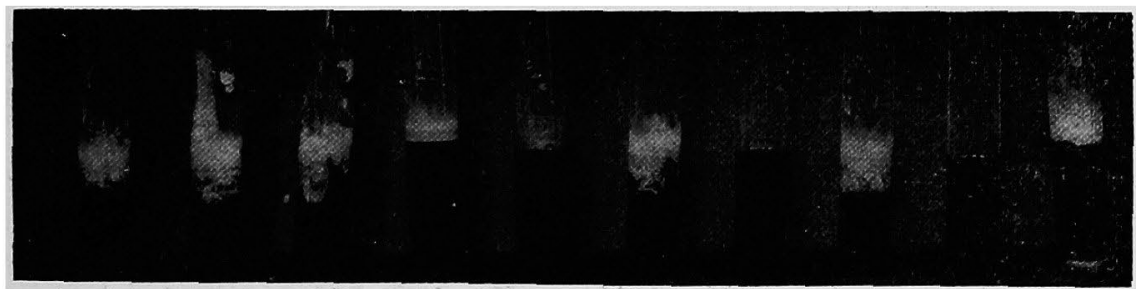

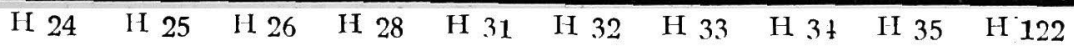

I) 液

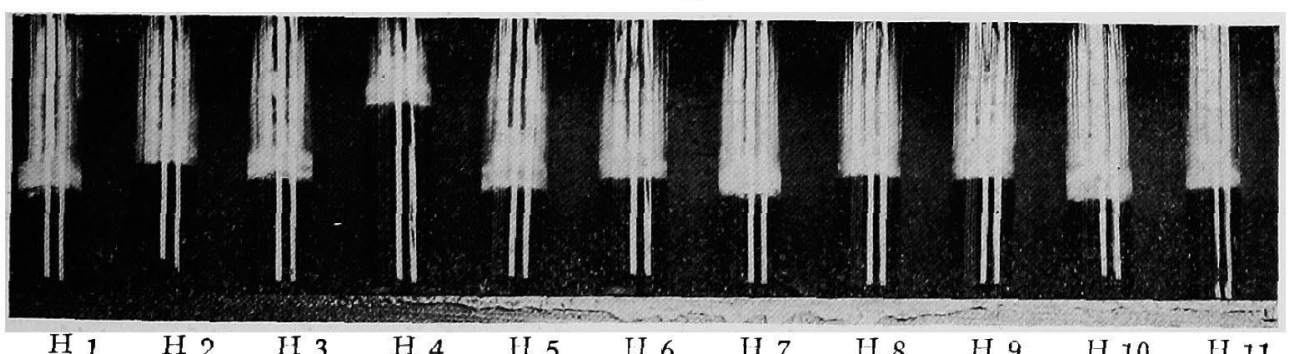

$\begin{array}{llllllllllll}\mathrm{H}_{1} & \mathrm{H}_{2} & \text { H } 3 & \text { H } 4 & \text { H } 5 & \text { II } 6 & \text { H } 7 & \text { H } 8 & \text { H } 9 & \text { H } 10 & \text { H II }\end{array}$

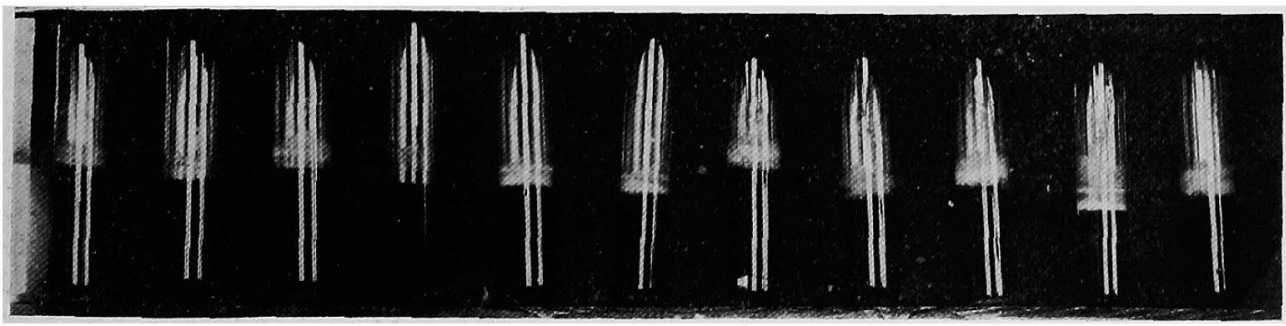

$\begin{array}{lllllllllllll}\text { H } 12 & \text { H } 14 & \text { H } 15 & \text { H } 16 & \text { H } 17 & \text { H } 18 & \text { H } 19 & \text { H } 20 & \text { H } 21 & \text { H } 22 & \text { H } 23\end{array}$

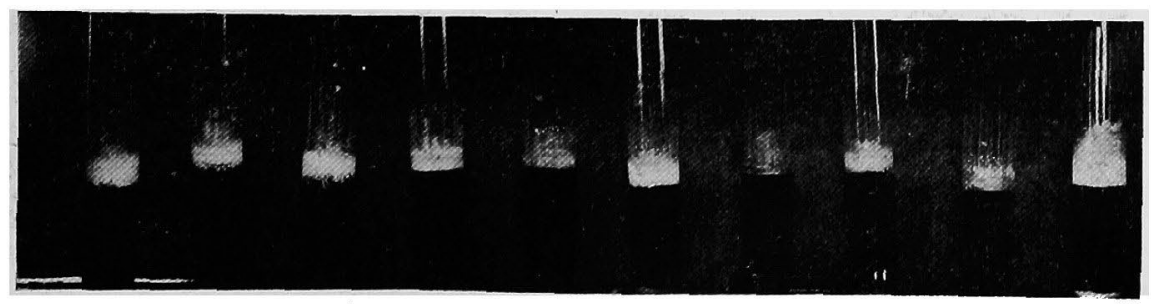

$\begin{array}{lllllllllll}\text { Ha24: } & \text { H } 28 & \text { H } 31 & \text { H } & 32 & \text { H } 33 & \text { HI } 34 & \text { H } 35 & \text { H } 122\end{array}$ 
淶汁 $\left(8^{\circ}\right)$ 食監 $10 \%$ 添加 $\left(25^{\circ} \mathrm{C}: 14\right.$ 日)

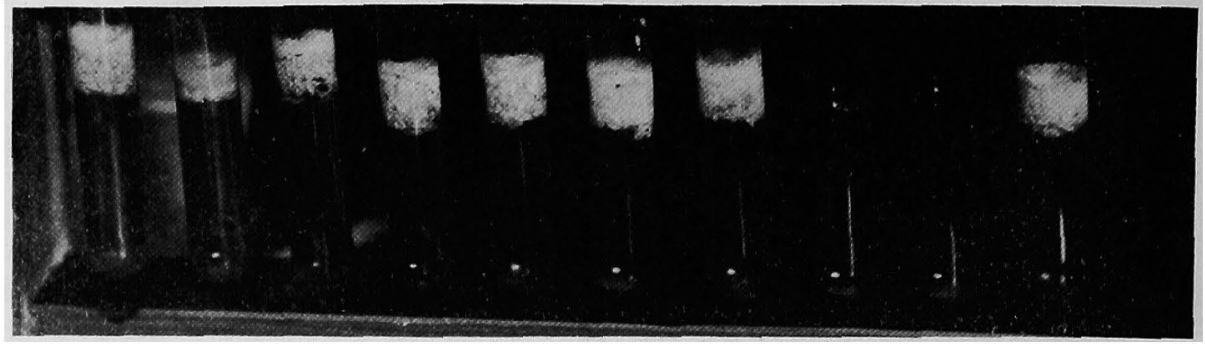

$\begin{array}{lllllllllllllllll}\text { H } 1 & \text { H } 2 & \text { H } & 3 & \text { H } & 4 & \text { H } & 5 & \text { H } 6 & \text { H } 7 & \text { H } 8 & \text { H } 9 & \text { H } & 10\end{array}$

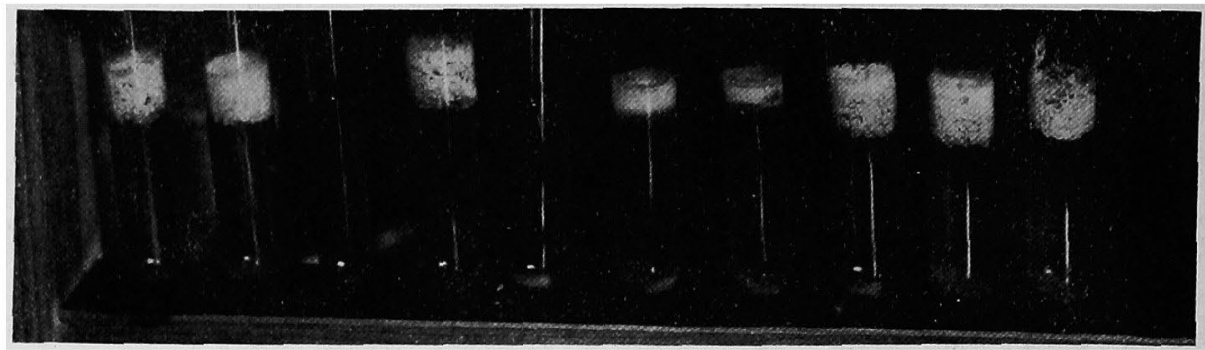

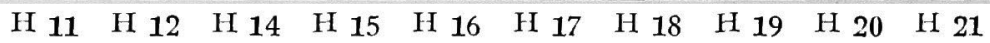

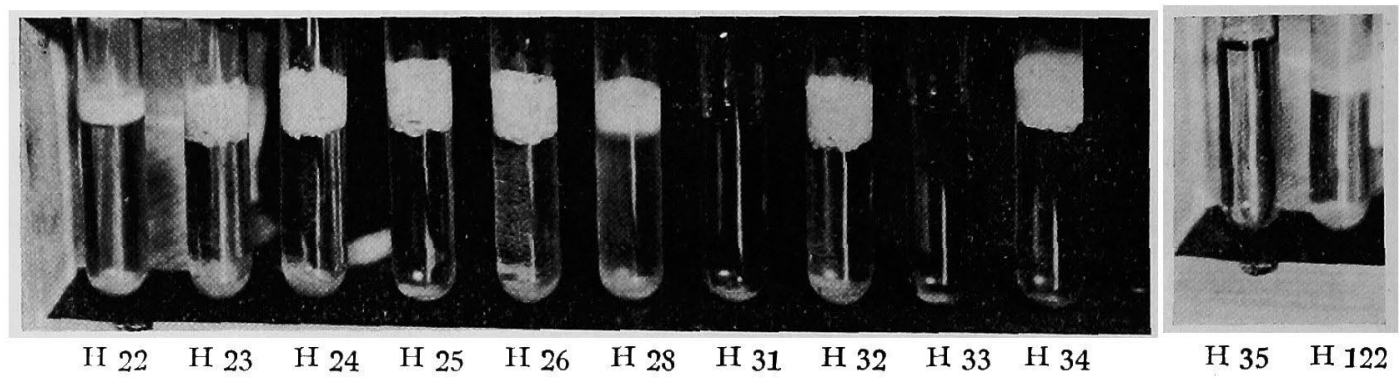

監汁 $\left(8^{\circ}\right)$ 食監 $20 \%$ 添加 $\left(25^{\circ} \mathrm{C}: 14\right.$ 日)

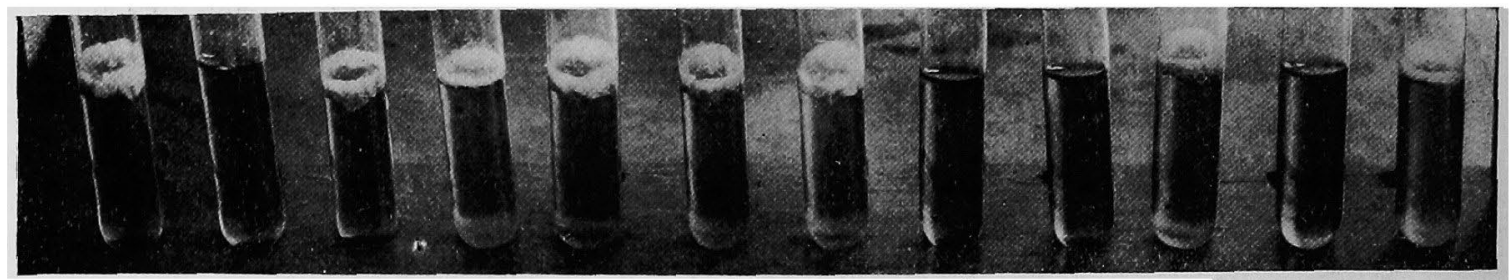
H 1 II 2
II 3
H 4 H 5
$\begin{array}{lllll}\text { H } 6 & \text { H } 7 & \text { H } 8\end{array}$
$\begin{array}{llllllll}\text { H } & 9 & \text { H } & 10 & \text { H } & 11 & \text { H } & 12\end{array}$

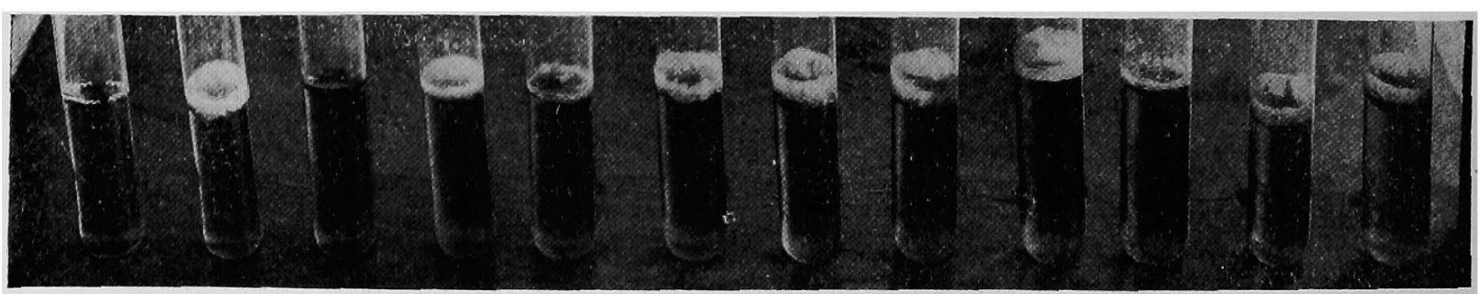

H 14 II 15

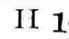

H 17 H 18

H 19

H 20

H $23 \quad$ H $_{2} 4$ H 25

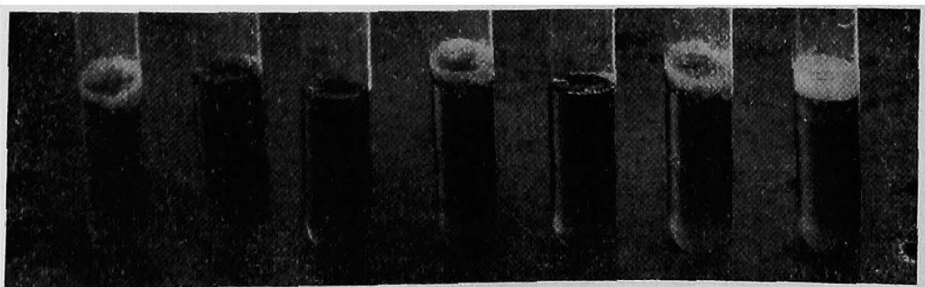

